\title{
Strontium and Cesium Radionuclide Leak Detection Alternatives in a Capsule Storage Pool
}

\author{
D. E. Larson \\ T. W. Crawford \\ S. M. Joyce
}

August 1981

Prepared for

Rockwell Hanford Operations

Pacific Northwest Laboratory

Operated for the U.S. Department of Energy

by Battelle Memorial Institute 
NOTICE

This report was prepared as an account of work sponsored by the United States Government. Neither the United States nor the Department of Energy, nor any of their employees, nor any of their contractors, subcontractors, or their employees, makes any warranty, express or implied, or assumes any legal liability or responsibility for the accuracy, completeness or usefulness of any information, apparatus, product or process disclosed, or represents that its use would not infringe privately owned rights.

The views, opinions and conclusions contained in this report are those of the contractor and do not necessarily represent those of the United States Government or the United States Department of Energy.

\author{
PACIFIC NORTHWEST LABORATORY \\ operated by \\ BATTELLE \\ for the \\ UNITED STATES DEPARTMENT OF ENERGY \\ Under Contract DE-AC06-76RLO 1830
}

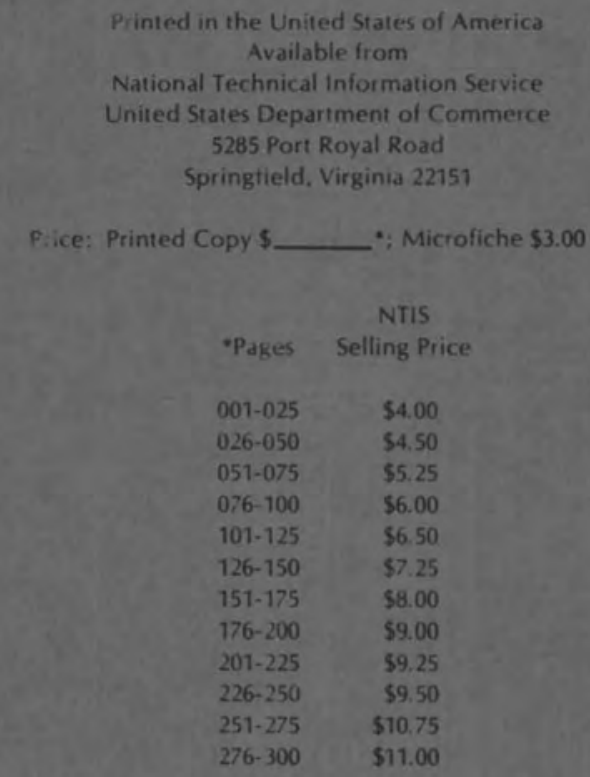


PNL -3844

UC -70

STRONTIUM AND CESIUM RADIONUCLIDE LEAK DETECTION ALTERNATIVES IN A CAPSULE STORAGE POOL

D.E. Larson

T.W. Crawford

S.M. Joyce

August 1981

Prepared for Rockwell Hanford Operations Under a Related Services Agreement with the U.S. Department of Energy under Contract DE-ACO6-76RLO 1830

Pacific Northwest Laboratory

Richland, Washington 99352 


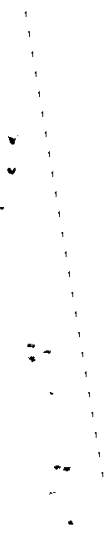




\section{ACKNOWLEDGMENTS}

The efforts of the following contributors were instrumental in producing this document:

- Peer Review:

W. J. Bailey

S. R. Doctor

C. J. Morris

R. M. Orme

J. 0. Honeyman
- Editing:

G. B. Long

- Word Processing:

M. A. Eierdam 


\section{ABSTRACT}

A study was performed to assess radionuclide leak-detection systems for use in locating a capsule leaking strontium-90 or cesium-137 into a waterfilled pool. Each storage pool contains about 35,000 L of water and up to 715 capsules, each of which contains up to $150 \mathrm{kCi}$ strontium-90 or $80 \mathrm{kCi}$ cesium137. Potential systems assessed included instrumental chemical analyses, radionuclide detection, visual examination, and other nondestructive nuclearfuel examination techniques. Factors considered in the assessment include: cost, simplicity of maintenance and operation, technology availability, reliability, remote operation, sensitivity, and ability to locate an individual leaking capsule in its storage location. The study concluded that an adaption of the spent nuclear-fuel examination technique of wet sipping be considered for adaption. In the suggested approach, samples would be taken continuously from pool water adjacent to the capsule(s) being examined for remote radiation detection. In-place capsule isolation and subsequent water sampling would confirm that a capsule was leaking radionuclides. Additional studies are needed before implementing this option. Two other techniques that show promise are ultrasonic testing and eddy-current testing. 

SUMMARY

Presently, there is an average of $78.4 \mathrm{kCi}$ of strontium-90 in each of 213 high-integrity capsules and $52.4 \mathrm{kCi}$ of cesium-137 in 740 high-integrity capsules stored in three water-filled pools. This strontium and cesium resulted from a Department of Energy program at Hanford to remove heat-producing isotopes from the stored high-level liquid wastes to enable further concentration of the waste for storage under acceptable thermal conditions. The cesium and

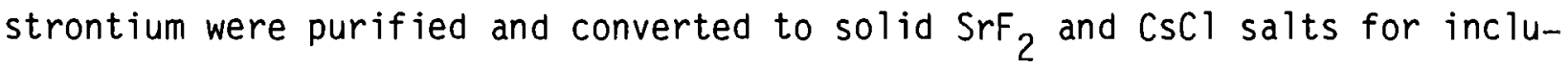
sion in metal capsules. These primary capsules are individually overpacked in a second metal container for underwater pool storage in the 225-B Building in the 200-E area at Hanford. In the remote circumstance that a capsule fails and leaks radionuclides to the pool, the capability exists to detect the leak. However, additional systems are needed to identify the leaking capsule so that it may be removed from the storage pool for repair and investigation. The purpose of this study is to assess leaking capsule identification concepts and to identify appropriate systems for application.

Guidelines used for system assessment included:

- leaking chemical or radiochemical detection sensitivity;

- cost;

- plant adaptability, operability, maintainability, and reliability;

- technology availability;

- ability for adaption to remote operation;

- capsule movement not required for leak detection;

- ability to identify individual leaking capsule;

- no need for trial and error approach.

Systems assessed included the following:

- Radiochemical Analyses

- gamma scan (spectrum shift)

- wet sipping 
- Chemical lnstrumental Analysis

- conductance

- specific-ion electrode

- Other Nondestructive Testing

- visual (periscope, photography, television)

- ultrasonic

- eddy current.

The study concluded that the in-situ wet sipping technique should be considered for application. This technique consists of continuously sampling the water for remote gamma spectrometry analyses, and shrouds may be used to isolate a rack of capsules or individual capsules, in-situ, from the rest of the pool. This technology is well established and routinely applied for inspection of spent nuclear fuel elements for leaks. For this technology adaption, some added study is needed to determine if the in-situ inspection technique can be implemented within the storage-array space restrictions.

Two other promising concepts for individual capsule inspection were identified: ultrasonic inspection and eddy-current testing. 
ACKNOWLEDGMENTS

ABSTRACT

SUMMARY

FIGURES

TABLES

INTRODUCTION

CONCLUSIONS

STUDY BASES

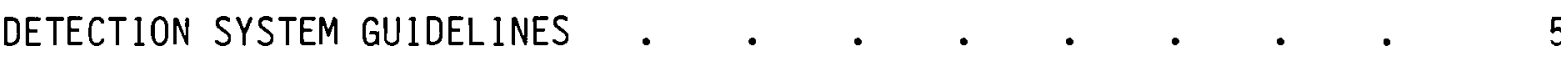

STUDY APPROACH •

CAPSULE STORAGE SYSTEM DESCRIPTION

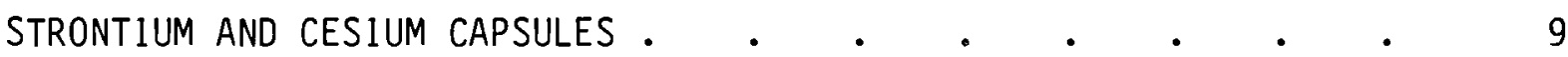

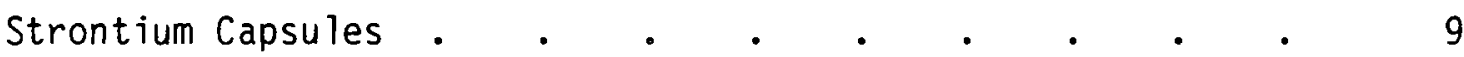

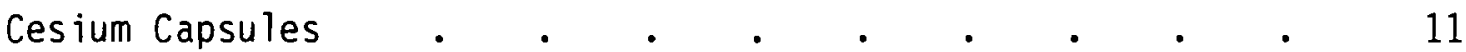

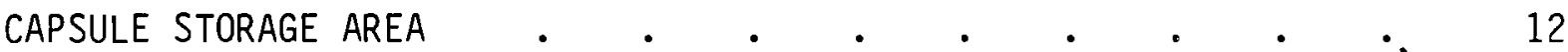

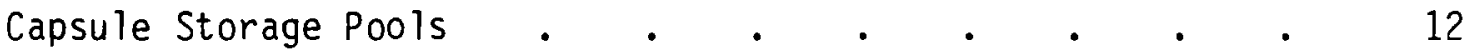

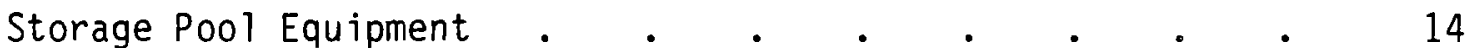

Pool Water Monitoring and Instrumentation $\quad . \quad$. $\quad . \quad$. 15

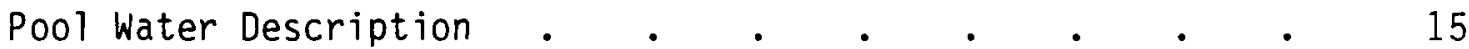

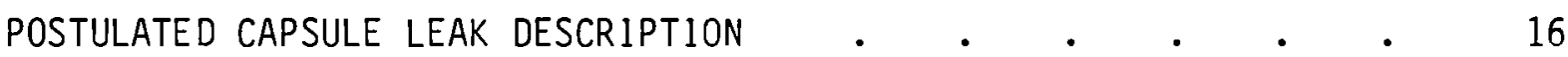

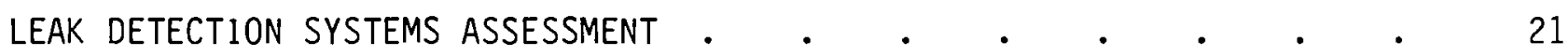

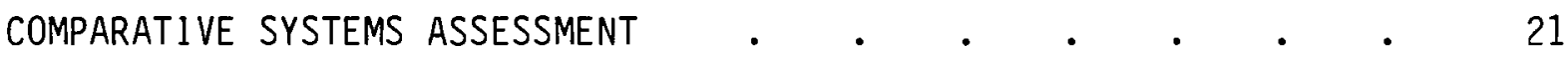

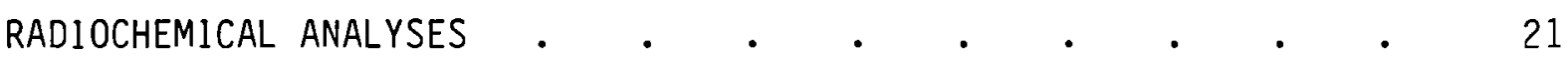

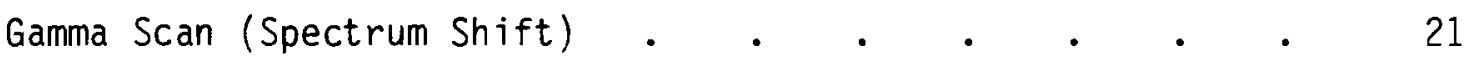




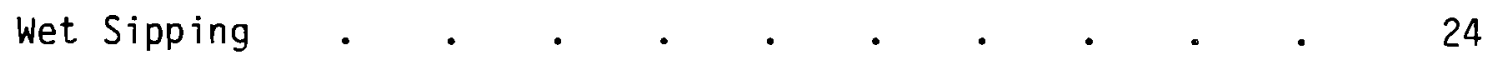

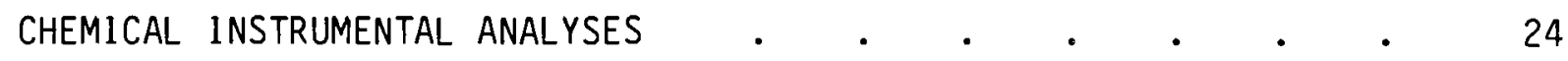

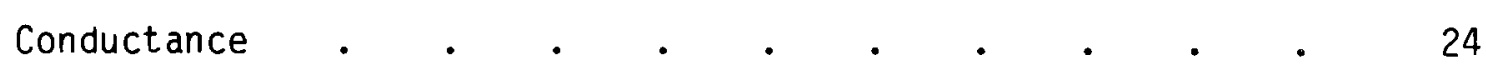

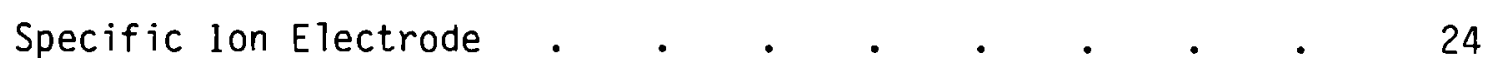

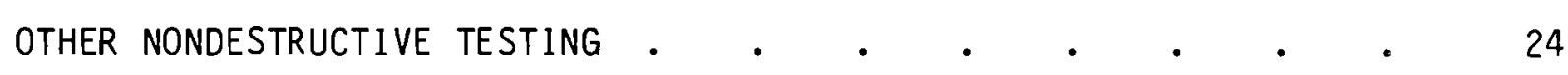

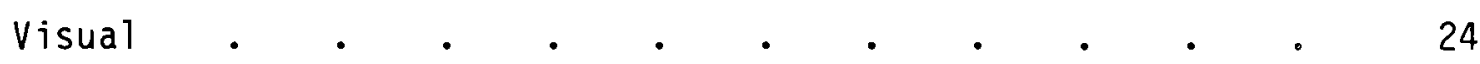

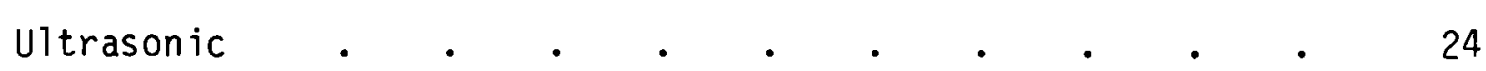

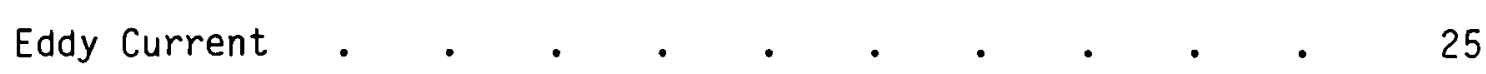

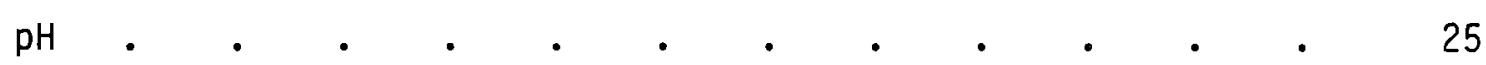

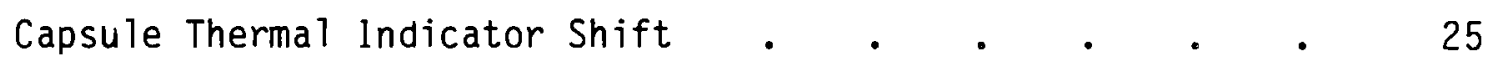

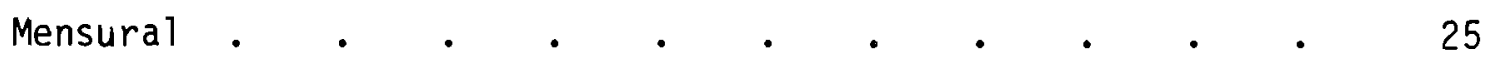

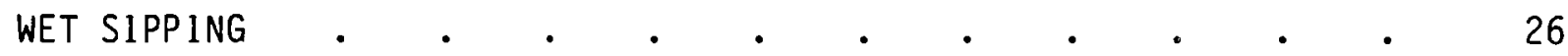

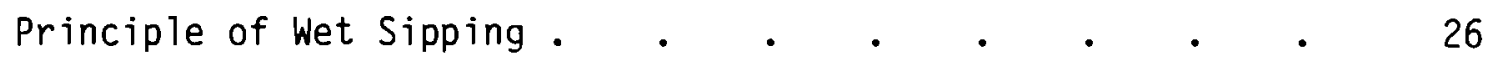

Description of Wet Sipping . . . . . . . . 27

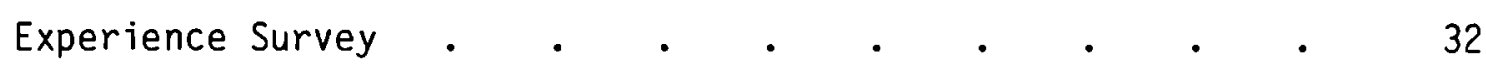

EDDY CURRENT TESTING

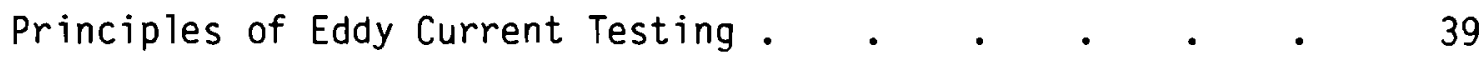

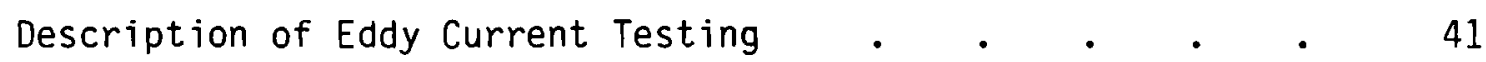

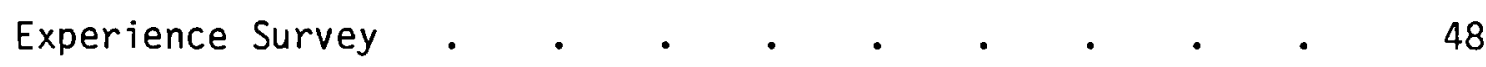

ULTRASONIC TESTING

Principles of Ultrasonic Testing . $\quad . \quad \ldots \quad$. $\quad . \quad 53$

Description of Ultrasonic Testing . $\quad . \quad$. $\quad . \quad$. $\quad . \quad 55$

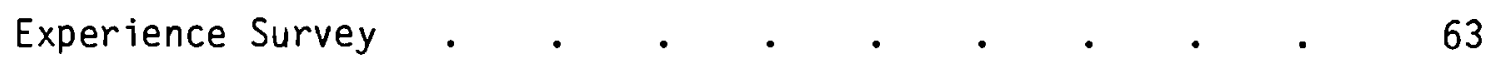

CONCEPTUAL DESCRIPTION OF WET SIPPING SYSTEM FOR 225-B

BUILDING POOL CELLS

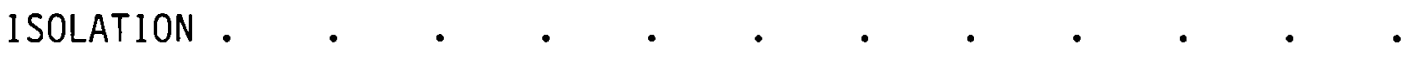




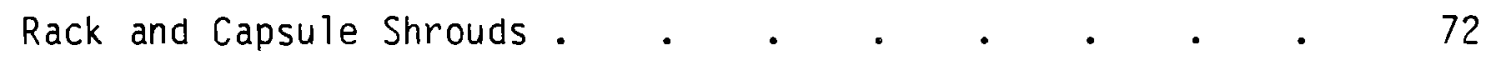

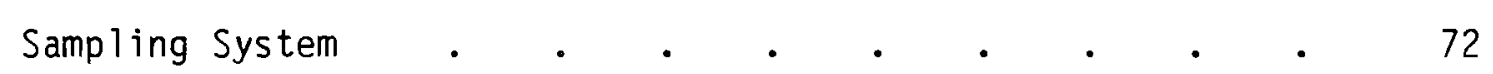

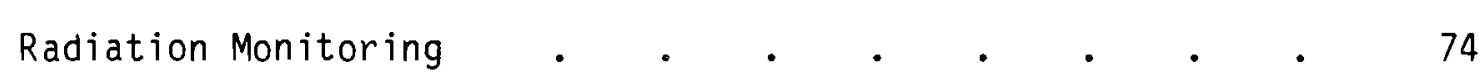

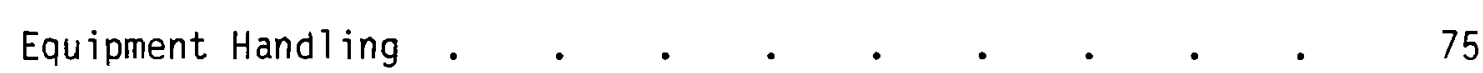

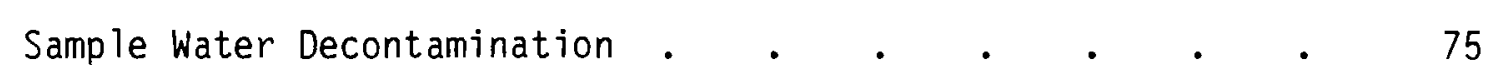

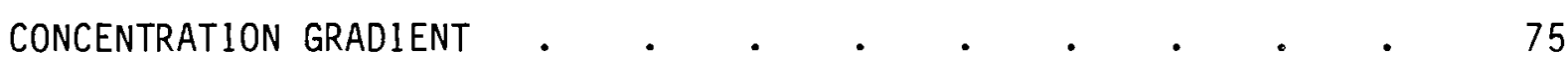

CONCEPT IMPLEMENTATION AND DEVELOPMENT • • • • • • • • 76

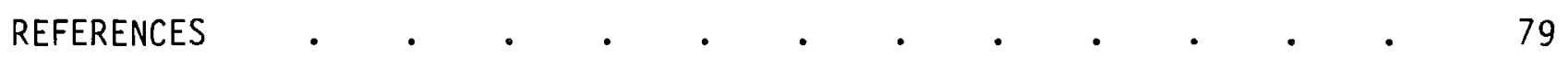





\section{FIGURES}

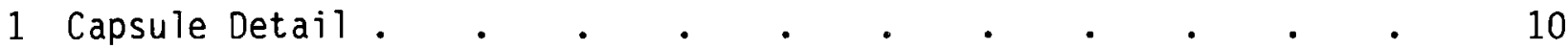

2 Diagram of Capsule Storage Area . . . . . . . . . 13

3 Schematic Diagram of Out-of-Core Wet Sipping of BWR

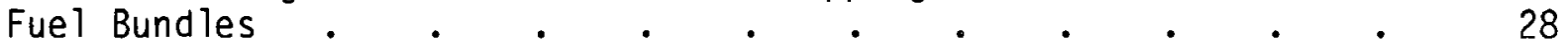

4 Cross Section of a Typical Sampler Used for In-Core Wet Sipping of BWR Fuel .

5 Eddy-Current Inspection at the Spent Fuel Storage Pool . . . 40

6 Block Diagram of Eddy-Current Test System . . . . . . 41

7 Differential Encircling Coil Probe . . . . . . . . . 42

8 Eddy-Current System Wheatstone Bridge Circuit . . . . 43

9 Example of Eddy-Current Inspection Station at Poolside . . . 46

10 Eddy-Current Poolside Inspection Data From an Irradiated Fuel Rod . $. \quad . \quad . \quad . \quad . \quad . \quad . \quad . \quad . \quad . \quad 47$

11 Forward Piezoelectric Effect (Electric Signal Input Mechanical Thickness Change - Acoustic Sound Pressure) . . . 53

12 Reverse Piezoelectric Effect (Acoustic Sound Pressure Mechanical Thickness Change - Electric Signal Output) . . . 54

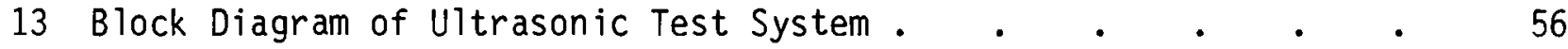

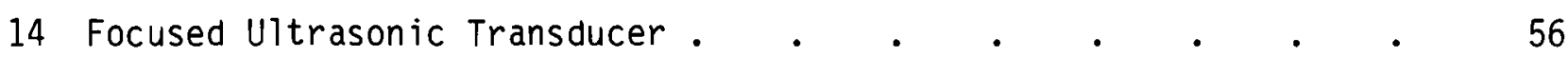

15 Functional Diagram of Pulse-Echo Ultrasonic
Instrumentation $\quad . \quad$.

16 Typical Ultrasonic Time-Amplitude Scan (A-scan)

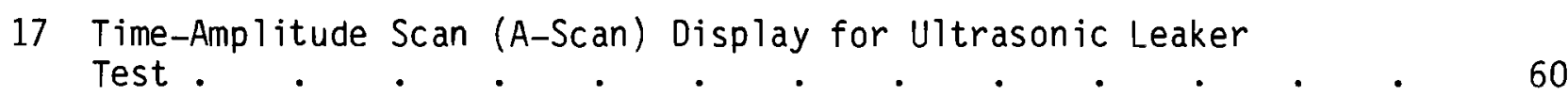

18 Special Device Used by a Foreign Company to Find Defective Fuel Rods by Detecting Water Inside the Rods ...$\quad$. . 61

19 Ultrasonic Defect Test that Employs $45^{\circ}$ Shear Waves . . . 62 
20 Wet Sipping System • . . . . . . . . . . . . 69

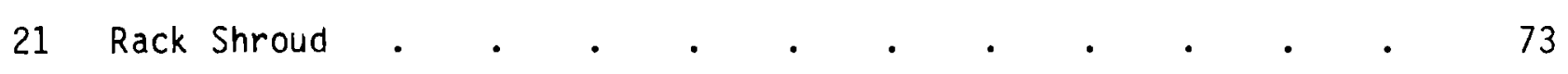

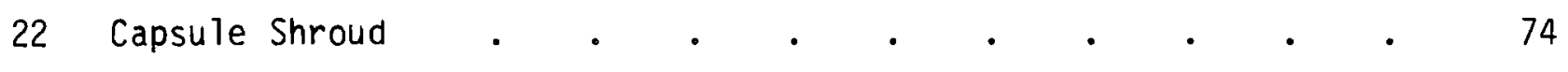




\section{TABLES}

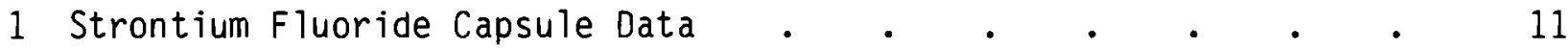

2 Typical Storage Basin Water Characteristics . . . . . . . 16

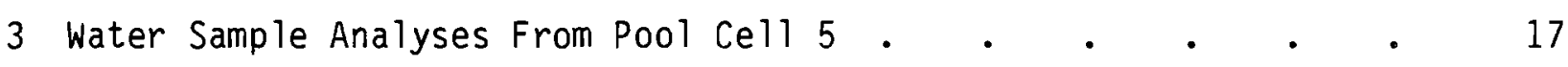

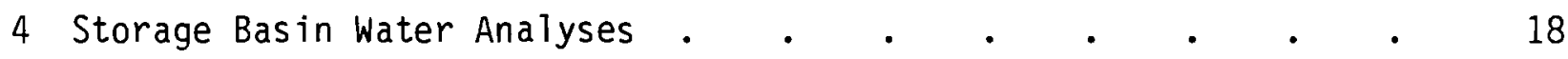

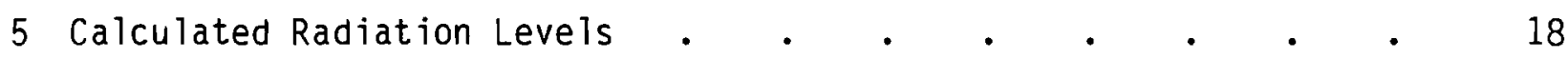

6 Assessment of Strontium and Cesium Leak Detection
Techniques

7 Comparison of Sipping Techniques Offered or Employed by Fue 1
Vendors and Utilities That Were Visited by NRC and PNL . . . .

8 Comparison of Characteristics of Sipping Systems in Current
Use.

9 Poolside Eddy-Current Inspection of Irradiated LWR Fuel $\quad$ - 49

10 Ultrasonic Properties of Zirconium and Zircaloy . . . . . 55

11 Wet Sipping Equipment Requirements . . . . . . . . 70 

INTRODUCTION

Rockwe 11 Hanford Operations has megacurie quantities of strontium-90 and cesium-137 stored in metallic capsules in water storage pools. As of March 1, 1981, there were 214 capsules of strontium-90, which contain an average of $78.4 \mathrm{kCi}$, and 740 capsules of cesium-137, which contain an average of $52.4 \mathrm{kCi}$. The capsules of strontium may contain up to a maximum of $150 \mathrm{kCi}$ strontium-90; the capsules of cesium may contain a maximum of $80 \mathrm{kCi}$ cesium-137. There is room in the storage pools for 7400 capsules.

The capsules are stored in three deionized water pools in the 225-B Building in the 200-East Area. Eleven pool areas are available for storage. Each pool provides a water radionuclide-activity monitor to determined the level of radiation in the pool water, and other monitoring is provided to determine the radiation level in the pool storage area. Thus, systems are provided to detect the increase or leakage of radionuclide activity.

The capsules were constructed as high-integrity containers for extended life and were designed so that failure in the storage pool would be a very low probability event. However, the possibility exists that a capsule could fail and release radionuclides to the pool, which would cause a high radiation zone in the pool area. Currently, a system is not available to search out and identify the source of radionuclide release to an associated pool.

This study identifies, assesses, and recommends capsule radionuclide leak source-detection concepts that may be developed and tested for facility implementation. First, the study describes the capsules and environment in which the capsules are stored, and some discussion on capsule failure is included. Then, the systems proposed for capsule failure detection are described and assessed. Based on the preliminary technique assessment, three methods (wet sipping, eddy current, and ultrasonic) are described and evaluated in more detail. Finally, suggestions are made as to the application of these techniques for the intended use. This study provides the bases for selecting a leak detection system and suggests an approach with two alternatives for final evaluation and development for plant application. 

CONCLUSIONS

A preliminary assessment was made of the following seven in-pool concepts for locating a leaking capsule of cesium or strontium stored in a capsule array in a water storage basin:

- gamma scan (spectrum shift).................

- wet sipping

- conductivity

- specific-ion electrode

- visual $\lambda$

- eddy current

- ultrasonic.

The conductivity, specific-ion electrode, and visual techniques were eliminated from detailed consideration since it was questionable whether they had the sensitivity to identify a leaking capsule under anticipated operating conditions. The gamma scan (spectrum shift) method needs more extensive analysis to determine its applicability; however, it is doubtful if this method has sufficient sensitivity to definitely identify a leaking element. Also, it is felt that the gamma scan approach offers no advantage over the systems considered in more detail.

Of the three remaining concepts (wet sipping, eddy current, and ultrasonic), each is industrially applied to identify leaking spent nuclear fuel elements in water-storage basins, and these technologies are directly applicable to detecting leaking capsules of strontium or cesium. Each technique is relatively sensitive to locating leakers, is simple and is inexpensive. The eddy current technique has two substantial disadvantages: 1) each capsule would have to be handled in the surveillance process, and 2) technology is not in use for in-pool surveillance to detect capsule flaws in the capsule lid edges (closure welds) where leaks are likely to occur. Eddy current data need skilled interpretation and independent methodology verification. The ultrasonic detection method also has the disadvantage in that each capsule has to be handled to enable surveillance. 
It is recommended that the wet sipping method be considered for implementation. The major advantage of this technique is that the capsules may not have to be moved for monitoring, and preliminary measurements can be made to reduce substantially the number of capsules that have to be individually monitored. Also, the capsule rack containing the leaking capsule can be isolated within the pool to inhibit leaking radionuclides from dispersing in the pool water. However, on a per capsule monitoring basis, the wet sipping method may be more time consuming than either the ultrasonic or eddy current techniques. Also, the recommended isolation wet sipping method may lose some absolute sensitivity by using an open-bottom shroud that enables in-situ surveillance. If experience shows that the isolation method is not sufficiently sensitive to positively confirm that a capsule is leaking, a secondary confirmatory technique, such as ultrasonic testing, would be appropriate. However, it is not expected that adequate sensitivity of the isolation method will be a problem. 
STUDY BASES

The study bases consist of establishing the guidelines that the detection systems have to meet, describing the study elements, and, finally, selecting the detection systems to be assessed.

DETECTION SYSTEM GUIDELINES

The radionuclide leak detection system will have to conform to the following guidelines:

- be able to detect desired strontium and cesium capsule constituent in pool water over the following concentration range--

Concentration

\begin{tabular}{cc}
$\frac{\text { Low }}{(10 \mathrm{mr} / \mathrm{h} \text { at }}$ & High \\
Pool Surface $(\mathrm{a})$ & Contents Dissolved) $(\mathrm{c})$ \\
\hline
\end{tabular}

Element/Units $\mathrm{mr} / \mathrm{h}$ Cs-137 Ci/L $\mathrm{d} / \mathrm{m} / \mathrm{mL}$

10

$6.2 \times 10^{-5}$

$1.4 \times 10^{5}$

10

$1.0 \times 10^{-4}$

$2.3 \times 10^{5}$

$1.7 \times 10^{-8}$

$1.5 \times 10^{-8}$

$1.7 \times 10^{-8}$

$3.0 \times 10^{-8}$
275,000 (b)

1.7

$3.8 \times 10^{9}$
- $\mathrm{Cs}^{+}, \underline{\mathrm{M}}$

- $\mathrm{Sr}^{++}, \underline{\mathrm{M}}$

- $\mathrm{Cl}^{-}, \mathrm{M}$

- $F^{-}, M$

(a) Approximate fraction, $3 \times 10^{-5}$, of capsule contents dissolved.

(b) Braden et al. (1971).

(c) Assume total strontium capsule contents dissolve, although this may not occur due to solubility limitations. 
- be adaptable for fully remote operation;

- be reliable;

- provide durable operation in plant environment;

- provide in-situ capsule leak-detection capability (highly desirable);

- be cost effective;

- be simple to operate by plant operators;

- be easily maintainable;

- provide minimal and easy calibration by plant operators;

- have detector (or sample point) capable of movement within pool;

- provide detector location (in pool) indication, enabling accurate detector placement or activity gradient mapping;

- enable easy decontamination and/or disposal of system components used in contaminated pool;

- discriminate between pool-water normal contaminant and leaked materials at normal pool-contaminant concentration.

- require no trial and error approach.

\section{STUDY APPROACH}

The following approach is used for this study:

- Detection system guidelines and plant environment are first defined to provide a framework for system assessment.

- Potential detection systems for application are then described and screened against the study bases to select the most promising concepts for more detailed assessment.

- Next, promising concepts are described and evaluated in greater depth in context of current applications. 
- Based on the concept assessment, the most promising concept is discussed in greater depth and conceptually defined, and some areas of study that need consideration before the implementation of the concept are identified.

- Finally, study conclusions are presented. 



\section{CAPSULE STORAGE SYSTEM DESCRIPTION}

This section provides the bases and defines the facilities within which the leak detection system has to operate. The facilities, equipment, and capsules (ARHCO 1973) used for storage in the 225-B Building of cesium and strontium are described. Also, accidents (Braden 1971) analyzed for cesium and strontium leakage to the pool are also discussed.

\section{STRONTIUM AND CESIUM CAPSULES}

The strontium and cesium capsules stored in the 225-B Building pools are described in this section.

Strontium Capsules

Pulverized strontium fluoride is loaded into a Hastelloy alloy C-276 capsule by impact consolidation, which is essentially a cold step-pressing operation. Next, the capsule is closed by tungsten-inert-gas (TIG)-welding a lid in place. The capsule is leak-checked and decontaminated. Then, the cleaned capsule is sealed in an outer capsule of $316 \mathrm{~L}$ stainless steel by TlG welding. The weld integrity of the outer capsule is checked using ultrasonic techniques. After weighing and calorimetry to determine heat output, the capsule is stored in a water-filled basin. The strontium capsule is illustrated in Figure 1.

The ${ }^{90} \mathrm{Sr}$ isotopic content of the $\mathrm{SrF}_{2}$ currently produced can vary from $\sim 55$ to as low as 25 to $30 \%$ depending on the age of the strontium. Pertinent data for a typical storage capsule that contains $\mathrm{SrF}_{2}$ that has an initial ${ }^{90} \mathrm{Sr}$ isotopic content of $55 \%$ are given in Table 1 . The heat output, power density and activity of the capsules will vary from the nominal values listed, depending on the initial ${ }^{90} \mathrm{Sr}$ content, and will decrease with time as the ${ }^{90} \mathrm{Sr}$ decays. The exposed metal surface-to-SrF 2 volume ratio (S/V) for the capsule is $\sim 0.86 \mathrm{~cm}^{-1}$.

The bulk density of the fluoride in the capsule is $\sim 65$ to $70 \%$ of the theoretical density, and each capsule contains $-3 \mathrm{~kg}$ of $\mathrm{SrF}_{2}$. The heat output of the capsule will depend on $i t s{ }^{90} \mathrm{Sr}$ content, which decreases with 


\begin{tabular}{|c|c|c|c|c|c|c|c|}
\hline & \multirow{3}{*}{$101 \mathrm{~m}$} & \multirow{3}{*}{ ionding } & \multirow{3}{*}{ 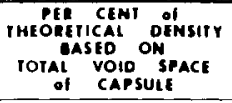 } & \multicolumn{4}{|c|}{ IEMPERALURE } \\
\hline & & & & \multicolumn{2}{|c|}{ AlR } & \multicolumn{2}{|c|}{ Walfe } \\
\hline & & & & CENIER IINE & SURface & CENIER LINE & SURFACE \\
\hline $\begin{array}{l}\text { STRONTIUM } \\
\text { FLUORIOI }\end{array}$ & $\begin{array}{l}\text { COMPACIID } \\
\text { pow DEF }\end{array}$ & Iso $\mathrm{KCC}$ & $n$ & $860^{\circ} \mathrm{C}$ & $560^{\circ} \mathrm{C}$ & $363^{\circ} \mathrm{C}$ & $\mathbf{1 2}^{\circ} \mathrm{C}$ \\
\hline $\begin{array}{c}\text { CESIUM } \\
\text { CHLORIOE }\end{array}$ & MELI-CAST & Bo kc & os & $210^{\circ} \mathrm{C}$ & ${ }^{40^{\circ} \mathrm{C}}$ & $86^{\circ} \mathrm{C}$ & $24^{\circ} \mathrm{C}$ \\
\hline
\end{tabular}
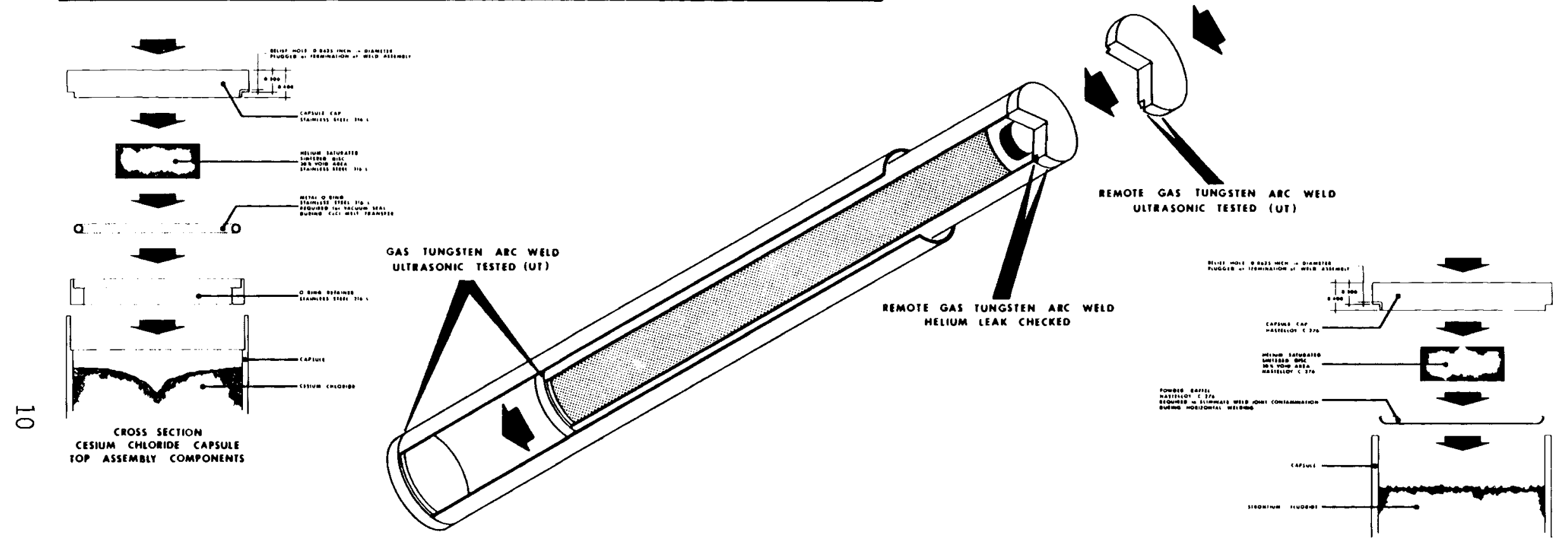

Cross SECTION

CROSS SECTION
STRONTIUM FEUORIOE CAPSUIE
TOP ASSEMEIY COMPONENTS

\begin{tabular}{|c|c|c|c|c|c|c|c|c|c|c|}
\hline & \multicolumn{10}{|c|}{ carsule } \\
\hline & \multicolumn{5}{|c|}{ TWHER } & \multicolumn{5}{|c|}{$\begin{array}{l}\text { ourte } \\
\end{array}$} \\
\hline & material & $\begin{array}{c}\text { WALIL } \\
\text { MHICKNISS }\end{array}$ & $\begin{array}{c}\text { OUISIOE } \\
\text { OIAMEIIER }\end{array}$ & $\begin{array}{c}\text { IOTAT } \\
\text { LINGGH }\end{array}$ & $\begin{array}{l}\text { TOIAL CAP } \\
\text { MHICKMES }\end{array}$ & Materiat & $\begin{array}{c}\text { WaAl } \\
\text { THICKNESS }\end{array}$ & $\begin{array}{l}\text { OUTSIDE } \\
\text { OIAMEIER }\end{array}$ & $\begin{array}{c}\text { TOTAL } \\
\text { IENGTH }\end{array}$ & $\begin{array}{l}\text { TOTA CAP } \\
\text { IHICKNESS }\end{array}$ \\
\hline $\begin{array}{l}\text { shonrium } \\
\text { fivoniog }\end{array}$ & $\begin{array}{l}\text { Masifitor } \\
\text { c-2ror } \\
\text { (uri) }\end{array}$ & $\begin{array}{l}0.120 \\
\text { (uit) }\end{array}$ & 2.250 & 19.050 & 0.400 & $\begin{array}{c}\text { STAINLESS } \\
\text { STEEL } \\
\text { J16 } \\
\text { IUTI } \\
\end{array}$ & $\begin{array}{l}0.120 \\
\text { (uII }\end{array}$ & 2.625 & 20.100 & 0.400 \\
\hline $\begin{array}{l}\text { CESIUM } \\
\text { CHIORIOE }\end{array}$ & 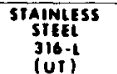 & $\begin{array}{l}0.095 \\
\text { iuri }\end{array}$ & 2.250 & 19.725 & 0.400 & 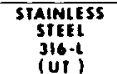 & $\begin{array}{l}\text { o. } \\
\text { ivit }\end{array}$ & 2.025 & $20.17 \mathrm{~s}$ & 0.400 \\
\hline
\end{tabular}

FIGURE 1. Capsule Detail 


\section{TABLE 1. Strontium Fluoride Capsule Data}

\begin{tabular}{ll}
\multicolumn{1}{c}{ Characteristics } & \multicolumn{2}{c}{ Value } \\
\cline { 1 - 1 } Amount & $\sim 2.8 \mathrm{~kg} /$ Capsule \\
Chemical Purity & $\sim 95 \%$ \\
$90 \mathrm{Sr}$ Isotopic Content & $\sim 55 \%$ \\
Bulk Density & $\sim 70 \%$ of Theoretical Density \\
Activity & $150,000 \mathrm{Ci} /$ Capsule Maximum \\
& $(\sim 78,400 \mathrm{Ci} /$ Capsule Average $)$ \\
Heat Load & $960 \mathrm{~W} / \mathrm{Capsule}$ Maximum \\
Power Density & $\sim 1.0 \mathrm{~W} / \mathrm{cm}^{3}$
\end{tabular}

time as the result of radioactive decay. The maximum heat output of the capsule at the time of encapsulation is up to $960 \mathrm{~W}$. This corresponds to a maximum capsule power density of $\sim 1 \mathrm{~W} / \mathrm{cm}^{3}$.

Cesium Capsules

Molten cesium chloride is cast in a cylindrical, type-316L stainless steel primary capsule that can contain about $60 \mathrm{kCi}$ of ${ }^{137} \mathrm{Cs}$ as a cesium chloride melt (maximum $\sim 80 \mathrm{kCi}$ ). The typical capsule is $19.7 \mathrm{in}$. long and has a 2.25-in. outside dia and a wall thickness of $95 \mathrm{mils}$. The capsules and end caps are weighed.

After the castings are cooled, the primary capsules are removed from the casting assembly and caps placed on them. The capsules are sealed by welding the caps to the capsules using TIG welding. A sintered disc saturated with helium is inserted under the cap before welding.

Each capsule is leak-tested by placing the sealed capsule in a watercooled vacuum chamber. After the chamber is sealed, the atmosphere is purged with argon gas and a vacuum drawn. A sample is taken of the chamber atmosphere, filtered, and passed through a helium mass spectrometer. If helium is detected, the capsule is opened and the cesium reprocessed. The sealed primary capsules are decontaminated by ultrasonic cleaning. The remaining steps of 
final decontamination of primary capsules, the final encapsulation, weighing, weld testing, calorimetry, and storage of the waste capsules in the storage basin, are similar to those previously described for strontium. The type-316L stainless steel outer containers are typically $20.8 \mathrm{in.}$ long, have a $2.625 \mathrm{in}$. outside dia, and a wall thickness of 109 mils.

\section{CAPSULE STORAGE AREA}

Filled capsules are transferred from a process cell (G Cell) into a waterfilled transfer aisle by a mechanical transfer device. Operators then use long-handled tongs to transfer the capsules to designated locations in each pool (see Figure 2 for diagram).

The storage pool area consists of 11 individual storage pools intended to provide isolation in the event a capsule should leak. Each pool is filled to a depth of $13 \mathrm{ft}$ with demineralized water and may be covered with concrete cover blocks to provide additional radiation shielding. One of the pools, which contains about twice the volume of each of the others, is used for continuous surveillance of $\sim 10 \%$ of the capsules. Surveillance of the effects of temperature and pressure on capsule outer dimensions, as well as ultrasonic testing to determine long-term integrity of capsule walls and welds, are expected to be performed.

The circulated water is also continuously monitored for radioactivity. The monitoring system is equipped with an audible alarm. At the present time, should radioactivity be detected, the contaminated water would be jetted to a hot cell for routing to either waste or rework, as appropriate. Before being returned to service, the pool would be decontaminated.

\section{Capsule Storage Pools}

The capsule storage area includes 1) 11 water pools, 10 of which are $4 \mathrm{ft}$ $5 \mathrm{in}$. wide by $21 \mathrm{ft} 9 \mathrm{in}$. long by $15 \mathrm{ft} 0 \mathrm{in}$. deep; and 2) the surveillance pool--8 ft $9 \mathrm{in}$. wide by $21 \mathrm{ft} 9 \mathrm{in}$. long by $15 \mathrm{ft} 0 \mathrm{in}$. deep. A narrow (3-ftwide) transfer aisle connects each of the storage pools. All pools are fully lined with $304 \mathrm{~L}$ stainless steel. Pool water is circulated through individual heat exchangers to maintain an outlet temperature below $125^{\circ} \mathrm{F}$ (normally about 


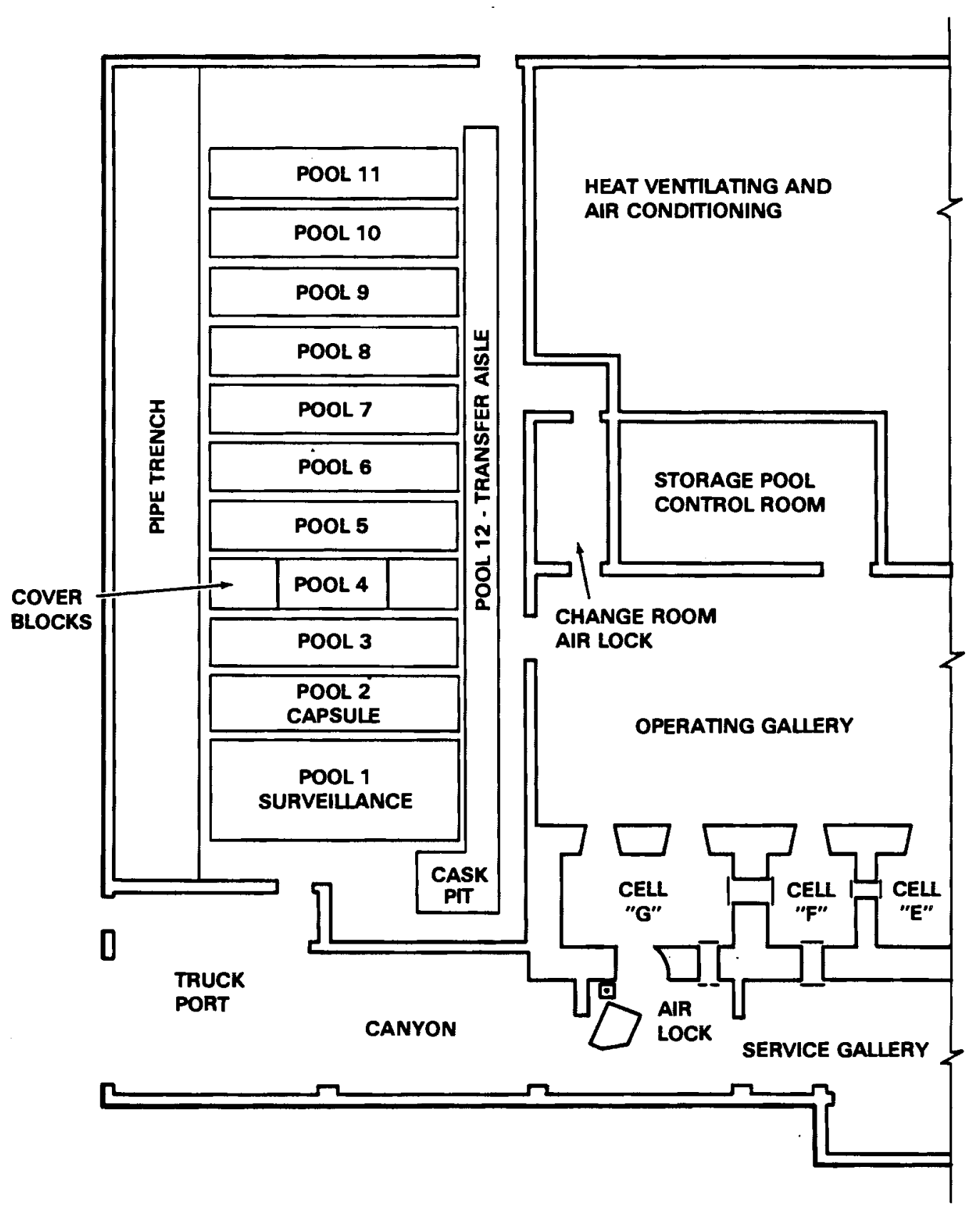

FIGURE 2. Diagram of Capsule Storage Area

$70^{\circ} \mathrm{F}$ ), and is routed periodically through a filter and demineralizer. This equipment is located in a 4-ft $\times 5-\mathrm{ft}$ pipe trench that extends the length of pool area. A 10-ton capacity bridge hoist is provided for cask and cover-block handling and equipment maintenance. Thirty-inch-thick concrete cover blocks can be installed over each pool. 
The capsule storage area is accessible from the operating gallery through a small change room and airlock. Personnel access to the capsule storage area is also provided from the truck port and from the outside entrance at the north end of the building.

Storage Pool Equipment

Capsule access to each storage pool from the transfer aisle is provided by a 4-in. isolation valve that prevents intermixing of the storage pool water with the water in the transfer aisle. The capsules are placed on-end in capsule storage racks under $13 \mathrm{ft}$ of water, which provides radiation shielding and cooling. The storage pool water is continuously circulated through a heat exchanger to remove heat that is generated by the capsules, and returned to the pool cell. Piping and valves are provided for routing the pool water through a demineralizer system.

Storage Pool Circulation Pumps

The pool-water circulation pump is a vertical, centrifugal pump capable of delivering a maximum of $100 \mathrm{gal} / \mathrm{min}$ at a total dynamic head of $100 \mathrm{ft}$ of water. The pump is fabricated from 300 Series stainless steel and is equipped with a 5-hp, 480-V, 3-phase, 60- $\mathrm{Hz}$ motor. The motor is flange-mounted to the pump casting in the valve pit. The pump is immersed in a well that is 12 in. below the liquid level of the storage pool water. The pool-cell water is circulated by the pump via a 3 -in. line to distributors located in the bottom of the pool.

\section{Heat Exchangers}

The pool-water heat exchanger is a spiral plate, counter-current type with a design cooling duty of $1.1 \times 10^{6} \mathrm{Btu} / \mathrm{h}$. The unit, $-3 \mathrm{ft}$ in dia by $3 \mathrm{ft}$ 2 in. long and fabricated from 300 Series stainless steel, is located in the storage pool above the water, near the pipe trench end. Raw water is used as the cold-side heat transfer fluid and is supplied from the main raw-water header. 


\section{Demineralizer System}

The demineralizer system is located in storage pool 11 and consists of two ion-exchange columns (C-S-1 and 2). These columns are connected in parallel and are operated together during water treatment. Each column is 12 in. in dia by $54 \mathrm{in.} \mathrm{high} \mathrm{and} \mathrm{fabricated} \mathrm{from} 300$ Series stainless steel. Each column contains $3.2 \mathrm{ft}^{3}$ of a nuclear-grade ion-exchange resin. The resin is a mixture of strong-base anion resin and strong-acid cation resin with a particlesize distribution that ranges from 16 to 50 mesh. The system as installed is nonregenerable. Spent resin, when not contaminated, is slurry-transferred from the columns into 55-gal disposal drums.

Pool Water Monitoring and Instrumentation

An in-line radiation monitoring system is installed in the coolant circulation line for each of the three used storage pools. The detectors are capable of detecting low-level concentrations of beta-gamma activity and are located in the pump inlet line. This assembly consists of a Geiger-Mueller tube and associated instrumentation. The monitoring station is panel-mounted in the operating gallery. Each detector input requires an amplifier, countrate meter, alarm module, and high-voltage power supply. The outputs are connected to rate-meter indicators.

Pool Water Description

The typical characteristics of water in a storage pool are summarized in Table 2.

The chemical analyses of samples of demineralized water placed in the pool before pool operation with capsules are shown in Table 3. Rockwell Hanford Operations staff feel that the concentrations shown are the upper concentration limit of impurities in the pool water during normal operation. Weekly samples are taken of the pool water, and typical analytical results are provided in Table 4. 
TABLE 2. Typical Storage Bas in Water Characteristics

\begin{tabular}{|c|c|c|}
\hline Characteristics & Typical Value & General Range of Value \\
\hline $\begin{array}{l}\text { Volume, } 4 \mathrm{ft} 5 \text { in. } x \\
21 \mathrm{ft} 9 \text { in. } x 13 \mathrm{ft}\end{array}$ & $35,000 \mathrm{~L}$ & -- \\
\hline pH & 6.5 & 1 to 4.5 \\
\hline Conductivity, $\mu \mathrm{mho} / \mathrm{cm}$ & 2 & 0.2 to 17 \\
\hline Total $\beta, \mu C i / m L$ & $2 \times 10^{-4}$ & $1 \times 10^{-4}$ to $6 \times 10^{-4}$ \\
\hline $\mathrm{Cl}, \mathrm{ppm}$ & $<10$ & 2 to 8 \\
\hline Temperature, ${ }^{\circ} \mathrm{F}$ & 70 & 70 to 75 \\
\hline $\begin{array}{l}\text { Rate of Pool Turnover, at } \\
380 \mathrm{~L} / \mathrm{min}\end{array}$ & $93 \min$ & -- \\
\hline
\end{tabular}

\section{POSTULATED CAPSULE LEAK DESCRIPTION}

The remote possibility exists that one of these capsules may leak, releasing radionuclide contamination to the pool water. The following potential causes of capsule failure are postulated:

- Corrosion of the capsule material greater than that anticipated from corrosion tests.

- Failure to maintain good quality control in the areas of material, welding, inspection, etc.

- Inadvertent mechanical damage, e.g., a cover block is dropped into the pool.

- Internal pressurization.

- Sabotage.

The only postulated radionuclide release would be to the storage basin water with little airborne release to the area ventilation air. The following effects are postulated in the event of radionuclide release: 


\section{TABLE 3. Water Sample Analyses From Pool Cell 5}

\begin{tabular}{|c|c|c|c|c|}
\hline Analyses & Sample 6563 & Sample & Average & $\mu \mathrm{mho} / \mathrm{cm}$ \\
\hline $\mathrm{pH}$ & 6.5 & 6.7 & 6.6 & \\
\hline Conductivity, $u$ mhos/cm & 36.3 & 36.0 & 36.2 & \\
\hline Total Beta, $\mu \mathrm{Ci} / \mathrm{L}$ & $2.24 \times 10^{-4}$ & $2.24 \times 10^{-4}$ & $2.24 \times 10^{-4}$ & \\
\hline $\mathrm{Cl}, \mathrm{M}$ & $4.56 \times 10^{-5}(1.6 \mathrm{ppm})$ & $4.75 \times 10^{-5}(1.7 \mathrm{ppm})$ & $4.66 \times 10^{-5}(1.65 \mathrm{ppm})$ & 3.5 \\
\hline $\mathrm{Na}, \mathrm{M}$ & $3.27 \times 10^{-4}$ & $3.14 \times 10^{-4}$ & $3.21 \times 10^{-4}(7.38 \mathrm{ppm})$ & 16.3 \\
\hline$K, M$ & $<1.62 \times 10^{-5}$ & $<1.58 \times 10^{-5}$ & $<1.60 \times 10^{-5}$ & \\
\hline$A 1, M$ & $<6.6 \times 10^{-4}$ & $<6.7 \times 10^{-4}$ & $<6.65 \times 10^{-4}$ & \\
\hline$M n, M$ & $<6.04 \times 10^{-5}$ & $<6.04 \times 10^{-5}$ & $<6.04 \times 10^{-5}$ & \\
\hline Sr, M & $<7.16 \times 10^{-6}$ & $<7.21 \times 10^{-6}$ & $<7.19 \times 10^{-6}$ & \\
\hline $\mathrm{Ni}, \mathrm{M}$ & $<2.53 \times 10^{-5}$ & $<2.45 \times 10^{-5}$ & $<2.49 \times 10^{-5}$ & \\
\hline $\mathrm{Fe}, \mathrm{M}$ & $<2.27 \times 10^{-5}$ & $<2.41 \times 10^{-5}$ & $<2.34 \times 10^{-5}$ & \\
\hline Mg, M & $<2.46 \times 10^{-5}$ & $<2.55 \times 10^{-5}$ & $<2.51 \times 10^{-5}$ & \\
\hline $\mathrm{Ag}, \mathrm{M}$ & $<1.4 \times 10^{-5}$ & $<1.33 \times 10^{-5}$ & $<1.37 \times 10^{-5}$ & \\
\hline $\mathrm{Ba}, \mathrm{M}$ & $<1.13 \times 10^{-5}$ & $<1.11 \times 10^{-5}$ & $<1.12 \times 10^{-5}$ & \\
\hline$B i, M$ & $<4.6 \times 10^{-5}$ & $<5.14 \times 10^{-5}$ & $<4.87 \times 10^{-5}$ & \\
\hline $\mathrm{Ca}, \mathrm{M}$ & $<1.139 \times 10^{-5}$ & $<1.32 \times 10^{-5}$ & $<1.23 \times 10^{-5}$ & \\
\hline$C d, M$ & $<5.19 \times 10^{-6}$ & $<5.22 \times 10^{-6}$ & $<5.21 \times 10^{-6}$ & \\
\hline $\mathrm{Cr}, \mathrm{M}$ & $<1.23 \times 10^{-4}$ & $<1.13 \times 10^{-4}$ & $<1.18 \times 10^{-4}$ & \\
\hline $\mathrm{Cu}, \mathrm{M}$ & $<1.80 \times 10^{-5}$ & $<2.34 \times 10^{-5}$ & $<2.07 \times 10^{-5}$ & \\
\hline Eu & & & & \\
\hline $\mathrm{Ga}$ & & & & \\
\hline $\mathrm{Hg}, \mathrm{M}$ & $<8.94 \times 10^{-5}$ & $<8.82 \times 10^{-5}$ & & \\
\hline La, M & $<1.30 \times 10^{-4}$ & $<1.29 \times 10^{-4}$ & & \\
\hline $\mathrm{Pb}, \mathrm{M}$ & $<2.15 \times 10^{-5}$ & $<6.91 \times 10^{-6}$ & $<1.4 \times 10^{-5}$ & \\
\hline Po & & & & \\
\hline $\mathrm{Rb}, \mathrm{M}$ & $<7.27 \times 10^{-6}$ & $<7.05 \times 10^{-6}$ & $<7.16 \times 10^{-6}$ & \\
\hline $\mathrm{Rh}$ & & & & \\
\hline Si, M & $<9.50 \times 10^{-4}$ & $<0.950 \times 10^{-4}$ & & \\
\hline$Y$ & & & & \\
\hline$Z r, M$ & $2.60 \times 10^{-4}$ & $2.80 \times 10^{-4}$ & $2.70 \times 10^{-4}(24.6 \mathrm{ppm})$ & 0.025 \\
\hline$C s, M$ & $<2.16 \times 10^{-5}$ & $<2.2 \times 10^{-5}$ & $<2.18 \times 10^{-5}$ & \\
\hline $\mathrm{CO}, \mathrm{M}$ & $<2.48 \times 10^{-5}$ & $<2.51 \times 10^{-5}$ & $<2.50 \times 10^{-5}$ & \\
\hline$Z n, M$ & $<8.5 \times 10^{-6}$ & $<8.29 \times 10^{-6}$ & $<8.40 \times 10^{-6}$ & \\
\hline $\mathrm{NO}_{2}, \mathrm{M}$ & $<2.46 \times 10^{-4}$ & $<1.98 \times 10^{-5}$ & $<1.33 \times 10^{-4}$ & \\
\hline $\mathrm{F}, \mathrm{M}$ & $4.86 \times 10^{-6}(0.4 \mathrm{ppm})$ & $\left(<6 \times 10^{-1} \mathrm{ppm}\right)$ & $(0.5 \mathrm{ppm})$ & \\
\hline $\mathrm{NO}_{3}, \mathrm{M}$ & $(<2.4 \mathrm{ppm})$ & $(2.4 \mathrm{ppm})$ & $(2.4 \mathrm{ppm})$ & \\
\hline $\mathrm{SO}_{4}, \mathrm{M}$ & $(<4.2 \mathrm{ppm})$ & $(<4.2 \mathrm{ppm})$ & $<4.3 \times 10^{-5}(<4.2 \mathrm{ppm})$ & \\
\hline $\mathrm{PO}_{4}^{4}, \mathrm{M}$ & $3.23 \times 10^{-5}(<3.1 \mathrm{ppm})$ & $(<3.4 \mathrm{ppm})$ & $(3.3 \mathrm{ppm})$ & \\
\hline $\mathrm{CO}_{3}, \mathrm{M}$ & $<2.3 \times 10^{-2}$ & $<2.3 \times 10^{-2}$ & & \\
\hline TOC, M & $<4.0 \times 10^{-2}$ & $<4.0 \times 10^{-2}$ & & \\
\hline
\end{tabular}


TABLE 4. Storage Basin water Analyses

\begin{tabular}{|c|c|c|c|c|c|}
\hline \multirow[b]{3}{*}{ Analyses } & \multicolumn{5}{|c|}{ Samp le } \\
\hline & $\begin{array}{c}E 5596 \\
(1 / 9 / 80)\end{array}$ & $\begin{array}{c}5848 \\
(2 / 6 / 80)\end{array}$ & $\begin{array}{c}6009 \\
(2 / 27 / 80)\end{array}$ & $\begin{array}{c}6374 \\
(4 / 2 / 80)\end{array}$ & $\begin{array}{c}6524 \\
(4 / 16 / 80)\end{array}$ \\
\hline & Pool No. 3 & Pool No. 3 & Pool No. 3 & Pool No. 3 & Pool No. 3 \\
\hline $\mathrm{pH}$ & 6.5 & 5.8 & 5.6 & 5.7 & 6.7 \\
\hline $\begin{array}{l}\text { Conduct ivity, } \\
u m h / \mathrm{cm}\end{array}$ & 8.90 & 2.90 & 1.85 & 0.0212 & 8.43 \\
\hline $\begin{array}{l}\text { Total Beta, } \\
\mu \mathrm{C} / \mathrm{mL}\end{array}$ & $3.03 \times 10^{-4}$ & $<1.69 \times 10^{-4}$ & $<3.6 \times 10^{-4}$ & $1.06 \times 10^{-4}$ & $<2.51 \times 10^{-4}$ \\
\hline $\mathrm{Cl}^{-}, \mathrm{M}$ & $<3.0 \times 10^{-6}$ & $<3.0 \times 10^{-6}$ & $<3.0 \times 10^{-5}$ & $9.35 \times 10^{-6}$ & $3.81 \times 10^{-5}$ \\
\hline
\end{tabular}

- Possible--Complete dissolution of the entire contents of cesium chloride or up to $15 \%$ of strontium fluoride from a capsule is possible. The dissolution rate of cesium chloride may be relatively rapid as a result of its high solubility. The strontium fluoride is only slightly soluble in water and, hence, the dissolution rate would be quite slow. In either case, the release of radionuclides to the cell air would be low.

Thirty-inch-thick shielding blocks constructed of regular concrete $\left(150 \mathrm{lb} / \mathrm{ft}^{3}\right)$ are available to cover each pool section, except for the surveillance pool and the pool being filled with capsules. Each normal storage pool will contain $\sim 35,000 \mathrm{~L}$ of water. On this basis, the calculated radiation levels above a contaminated basin section would be as shown in the table below:

Storage basin ventilation air is routed to the stack through two HEPA filters via the $\mathrm{K}-1$ filter system. Contaminated storage bas in water

\section{TABLE 5. Calculated Radiation Levels}

\begin{tabular}{|c|c|c|}
\hline \multirow[b]{2}{*}{ Containment } & \multicolumn{2}{|c|}{ Gamma Radiation Level } \\
\hline & Blocks On & Blocks off \\
\hline $\begin{array}{l}\text { One Cs Capsule } \\
60,000 \mathrm{Ci} 137 \mathrm{Cs}\end{array}$ & $0.54 \mathrm{mR} / \mathrm{h}$ & $275 \mathrm{R} / \mathrm{h}$ \\
\hline $\begin{array}{l}\text { One Sr Capsule } \\
150,000 \mathrm{Ci} 90 \mathrm{Sr} \\
\text { (Assume full dissolution) }\end{array}$ & $0.24 \mathrm{mR} / \mathrm{h}$ & $400 \mathrm{R} / \mathrm{h}$ \\
\hline
\end{tabular}


can be jetted to B Plant for rework if dose rates permit entry into the pool room. Strontium-contaminated water would be concentrated in Cell 23 before rework in the solvent extraction columns. Cesiumcontaminated water would be reworked in Cells 18,19 and 20 of B Plant by ion exchange.

- Probable--Only a single capsule failure at any given time is probable. The postulated leak is expected to be small in size; consequently, leaching will be restricted. Early detection could prevent the complete dissolution of the capsule contents.

Several design features have been incorporated into the facility, equipment and capsules to prevent capsule failure and mitigate the effects should a capsule fail:

a. An extensive research and development program has been conducted to establish a technical basis for selection of the capsule materials. Hastelloy $\mathrm{C}-276$ and type-316L stainless stee 1 have been selected as compatible capsule materials for strontium fluoride and cesium chloride, respectively. All products will be doubly encapsulated.

b. Automatic welding equipment is used to maintain weld quality. Inner capsules will be checked for leakage by helium-leak check immediately after welding. The capsule will then be ultrasonically cleaned, inserted into the outer capsule, and welded. A final ultrasonic scan will check the weld quality.

c. Safety features incorporated in the basin crane and cover block designs reflect the operating experience of extensive "canyon"type work at Hanford. Operating safety practices include routine crane inspections, e.g., of cables, brakes, etc. Continuous monitoring of the basin water provides for detection of a failed capsule. 
. 
Capsule leak detection methods considered for utilization are described and assessed in this section. A preliminary screening is performed of the systems considered, and in subsequent discussions, systems that warrant additional consideration are described and assessed. The additional descriptions and assessments summarize concept descriptions as applied to spent nuclear-fuel leak detection, which are directly applicable to the use considered in this study. The material in these sections is drawn extensively from a study by Bailey et al. (1980a,b, Vol. 1 and 2) for the Nuclear Regulatory Commission (NRC) on spent fuel examination in water pools.

\section{COMPARATIVE SYSTEMS ASSESSMENT}

Listed below are the capsule leak detection methods considered. These systems are compared in Table 6 .

Radiochemical Analyses

- Gamma Scan (Spectrum Shift)

- Wet Sipping

Chemical Instrumental Analysis

- Conductance

- Specific Ion Electrode

Other Nondestructive Testing

- Visual (Periscope, Photography, Television)

- Ultrasonic

- Eddy Current

RADIOCHEMICAL ANALYSES

Gamma Scan (Spectrum Shift)

Suspect leaking capsules are placed in a fixture located in the pool. Each capsule is scanned for a shift in the capsule gamma spectrum emissions that would be caused by water intrusion into the capsule. 


\section{TABLE 6. Assessment of Strontium and Cesium Leak Detection Techniques}

$\frac{\text { Leak Detection Method }}{\text { Radiochemical Analyses }}$
Wet Sipping
Gamma Scan (Spectrum Shift)
Chemical Instrumental Analys is

Conduct ance

\section{-Simple} -Economical

-Fairly accurate

- Capsules need not be

handled

-Simple
-Economical
-Rapid

-Simple
-Economical
-Reliable
-Good sensitivity to ion
activity
-Rapid

Specific lon Electrode

-Simple

-Economical

-Chemical specie-speci-

fic

-Rapid

\begin{tabular}{l} 
Disadvantages \\
\hline -Method slow \\
-Results may not be con- \\
clusive for small leaks \\
\\
-Requires handling of \\
each capsule \\
-Requires limited inves- \\
tigation and develop- \\
ment \\
-Accuracy and reliabil- \\
ity currently uncertain
\end{tabular}

-Competing ion inter-

Nondestructive Examination

\section{Visual:}

Periscope

Photography

Television

Eye

Binoculars to detect leaking flaw
- Inability to distinguish between ionspecies

-Desired ionic activity low compared to normal pool contamination ion-activity

-Requires periodic calibration ferences

- Temperature change-sen-

sitive

Desired ionic activity low compared to normal pool contamination $\left(\mathrm{Sr}^{++}, \mathrm{Cs}^{+}, \mathrm{Cl}^{-}, \mathrm{F}^{-}\right)$

-Used industrially for spent nuclear fuel leak detection

-Gamma scanning spent fuel elements for fue fuel elements for fue technology, but its application to detect gamma spectrum shift rom water intrusion into the capsule would require investigation/ deve lopment

- Industrially applied for water quality analyses. Not currently in use for nuclear chemical analyses

- Industrially applied for chemical analyses for nonnuclear and nuclear applications - Inadequate (b) for application due to inadequate sensitivity

Marginal(a) for application due to sensitivity in presence of nor mal pool chemical contaminants

-Each capsule needs to be handled

- Resolution not adequate -Capsule handling is

extensive or capsule surveillance equipment could be complex
- Shoula be strongly considered for application

Additional investigations are needed before final assessment can be made, but it is felt that scan may not be conclusive
-Applied technology to make a preliminary assessment of spent fuel bundle condition
- Inadequate for appliquate sensitivity cation due to inade- 


\section{TABLE 6. (contd)}

Leak Detection Method Nondestructive Examination (contd)

Ultrasonic

Eddy Current
Advantages

-Simple
-Rapid
- Inexpensive
-Reliable
-Provides data on cap-
sule condition (gives
possible early warn-
ing of leak)

\section{-Simple}

- Inexpensiv

- Reliable

Provides data on cap-

sule condition (gives

possible early warn-

ing of leak)

\begin{tabular}{l} 
Disadvantages \\
\hline \\
-Requires handling of \\
each capsule \\
-Method needs some adap- \\
tion development \\
\\
-Requires handling of \\
each capsule \\
-May be difficult to \\
detect leakes arround \\
top and bottom edges \\
-Defect indication may \\
require secondary \\
method verification \\
-Measurements difficult \\
to interpret \\
-Method needs some adap- \\
tion development
\end{tabular}

Technology Status

Technique Assessment

-Applied technology to

determine spent nuclear

fuel pin integrity

under water. Used for

hot cell fuel pin exam-

ination

-Applied technology to detect flaws in spent fuel element pins under water. Used for hot cell fuel pin flaw examination

-Should be considered for application (see page 39 "Eddy Current Testing.")

- May be considered further for application, but it is felt that this concept is less desirable than wet sipping or ultrasonic testing (see page 52, "Ultrasonic Testing.")

(a) A preliminary assessment indicates that the pool-water conductance from capsule contents would increase by roughly $5 \times 10^{-3}$ umho/cm to cause a pool surface dose rate of $10 \mathrm{mr} / \mathrm{h}$ and $50 \mu \mathrm{mho} / \mathrm{cm}$ if a whole capsule contents dissolved. Since it would be desirable to detect the radionuclide leak at a low pool surface dose rate, and the normal pool water conductivity ranges between 0.2 to 17 , it could be difficult to locate the leak within the normal water conductivity fluctuations within the pool.

(b) A preliminary assessment indicates that the specific ion concentration increases ( $\mathrm{Sr}, \mathrm{CS}, \mathrm{Cl}, \mathrm{F}$ ) as shown on page 5 , "Detection System Guidelines," would be present for the two capsule leaking conditions addressed. Pool-water samples have indicated the specific ions of interest to normally be present in the concentrations of $10^{-5}$ to $10^{-6} \mathrm{M}$. Also, there may be interfering ions present on the same order of concentration. Specific ion electrode sensitivities are claimed good down to $-10^{-6} \mathrm{M}$ (probably under optimum conditions). This lower limit sensitivity is on the level of normal extraneous chemical concentrations and not sufficient to detect specific ions at a concentration increase of $\sim 10^{-8} \mathrm{M}$, which would occur for leaking radionuclides to produce a $10 \mathrm{mr} / \mathrm{h}$ dose rate at the pool surface. 


\section{Wet Sipping}

Suspect leaking capsule(s) is placed in a water-filled container (shroud) where the associated water is monitored for an increased radionuclide concentration from the leaking container. (A variation of the wet sipping technique considered is to monitor the pool water with a movable-point radionuclide concentration indicator. The increasing radionuclide concentration in the water source is followed to the leaking capsule.)

CHEMICAL INSTRUMENTAL ANALYSES

Conductance

The increase in pool water conductance caused by dissolved capsule chemicals is monitored, and the pool water conductance gradient is determined and followed by continuous point sampling in order to locate the leaking capsule where the conductance would be the highest.

Specific Ion Electrode

The increase in concentration of specific ions $\left(\mathrm{Cs}^{+}, \mathrm{Sr}^{++}, \mathrm{Cl}^{-}\right.$, and $\left.\mathrm{F}^{-}\right)$ caused by dissolved capsule chemicals is monitored. The specific ion gradient in the pool water is determined and followed by continuous point sampling to locate the leaking capsule, where the specific ion concentration is the highest.

\section{OTHER NONDESTRUCTIVE TESTING}

$\underline{\text { Visual }}$

Capsules in a fixture are visually inspected in the pool water with binoculars, periscope, television or photography to identify the leak area in the capsule.

Ultrasonic

Capsules in a fixture are tested with an ultrasonic sensor in the pool water to detect if water is contained within the outer capsule. 


\section{Eddy Current}

Capsules in a fixture are scanned with an eddy current detector to test for flaws in the outer capsule.

A confirmatory method to detect a leak for the above approaches would be to turn the capsule upside down and "listen" for a thump. If void between inner and outer capsule is filled with water, there would be little noise of impact due to capsule movement resistance. Some testing would have to be performed to confirm concept practicality.

Other systems proposed but determined not to be applicable include the following:

$\underline{\mathrm{pH}}$

Testing for change in pool-water $\mathrm{pH}$ for $\mathrm{SrF}_{2}$ and $\mathrm{CsCl}$ that dissolves into the pool does not appear feasible. The dissolution of these salts should not change the detectable hydrogen ion concentration in solution since these salts and solubility products are highly ionized.

Capsule Thermal Indicator Shift

A concept was developed that assumes temperature changes (shift in energy emission spectra from the capsule surface), or capsule power production changes if water intrudes into the annulus between the primary and secondary capsule or into the primary capsule. However, the capsule surface temperature and power production do not change with water intrusion into the capsule since 1) the capsule radionuclide inventory will not change significantly (unless a substantial fraction of radionuclide inventory was removed from the capsule), and 2) the temperature-determining conditions for the capsule surface are not altered.

\section{Mensural}

Mensural techniques used to measure changes in spent nuclear fuel dimensions are not felt to be applicable since a breach in capsule integrity caused by corrosion is not likely to cause changes in capsule dimensions. 


\section{WET SIPPING}

Wet sipping is a technique commonly used in commercial reactors and spent nuclear fuel storage basins to identify spent fuel elements that leak radionuclides. Fission-product activity in the reactor coolant at higher than normal background levels $(a)$ is an indication that perforation of fuel rod cladding has occurred (Green 1978b). Evaluation of fuel by sipping is used when it is practically certain that the reactor core contains failed fuel (i.e., the reactor coolant activity is judged to be excessive) (IAEA 1978). With commercial reactor fuel, sipping is normally performed onsite during scheduled refueling outages. Sipping as a means of detecting leaker bundles is not an exact diagnostic technique. Sipping preferentially identifies fuel cladding breaches that happened late in the reactor cycle (Gelhaus 1977). Direct adaption of this technique would be simple, since the application and circumstances are similar, and no significant verification development would be needed.

Principle of Wet Sipping

The principle of sipping is based on determining the presence and magnitude of escaping fission products from leaking containers (capsules) that are in a sipping apparatus (capsule shroud). In variation of the normal sipping technique (considered in conjuction with the normal method), samples of the water in the pool that contains the leaking capsule are continuously taken. This enables the detector to follow an increasing radionuclide concentration in the pool to the leak source.

To detect successfully a failed capsule by sipping, material must be expelled from the capsule, which produces the radiochemical (or other) signal. However, a breach in the container may only allow a small release of radionuclides into the water in the sipping apparatus, and meaningful data cannot be obtained unless significant buildups of these radionuclides above normal background are present.

(a) Uranium present in core components or uranium impurities previously deposited on reactor internals produce the background radiation (Green 1978 b). 
Thus, the suspected leaking capsule(s) is isolated from its normal pool environment by being placed into a water-filled container (shroud). The container water is sampled for radionuclide buildup and is compared with normal radionuclide background in the water. The sipping container is usually fully closed, but in this application a container with an open bottom--a "bell jar"-is considered for use to enable in-situ sipping. Since the water in the sipping container is not completely isolated from the storage pool water, a measurement uncertainty is added. However, the sipping method simplification (in-situ testing) warrants this variation, and it is not felt that accuracy is significantly compromised.

A substantial variation of this technique is continuous point sampling of capsule storage pool water for radionuclide concentration increases in the water as the capsule is approached. A leaking capsule provides a point source of radionuclides entering the pool. The concentration of radionuclides in the pool water would decrease with distance from the capsule, thus providing a radionuclide concentration gradient. This gradient may be followed to the leaking capsule. The implementation of this technique may be substantially complicated by pool-water flow patterns and a probable low radionuclide release rate from the capsule.

Description of Wet Sipping

The sipping systems considered--"isolation" and "concentration gradient"-are described beginning on page 69. To enable detailed assessment and use of these techniques, existing practice with spent fuel wet-sipping methods are briefly described, since the technology is currently applied to spent fuel.

Spent fuel wet sipping could be adapted directly to capsules. In general, the technique involves testing a fuel bundle under water in the spent fuel pool (called "out-of-core sipping") or in the reactor core (called "incore sipping") and identifying those bundles that leak by detecting the release of leachable fission products (primarily iodine and cesium) to an isolated volume of coolant. One advantage of wet sipping is the inherent safety of the technique: the fuel bundle is always submerged in water. 
The sensitivity and reliability of wet sipping is measurably increased with $100 \%$ isolation, making this situation most desirable (Green 1978b). Outof-core wet sipping is employed at most light-water reactors (LWRs). The method is to remove a fuel bundle from the core and to isolate it in a sealed can in the spent fuel storage pool.

An example of out-of-core wet sipping equipment for boiling-water reactor (BWR) fuel is shown in Figure 3. The individual fuel bundles are moved into the isolated environment (an enclosed sipping can). Similar equipment is used with pressurized-water-reactor (PWR) fuel.

In most cases of out-of-core wet sipping, after the fuel bundle is loaded into the can and the can lid is sealed, the contaminated water (i.e., spent fuel pool water) inside the can is replaced with clean, demineralized water to reduce the background. The pool water is expelled from the can interior by using 1) compressed dry air or nitrogen, after which the can is filled with demineralized water, or 2) forced circulation flushing with demineralized water. The contained water is allowed to heat up ("soak") for a predetermined

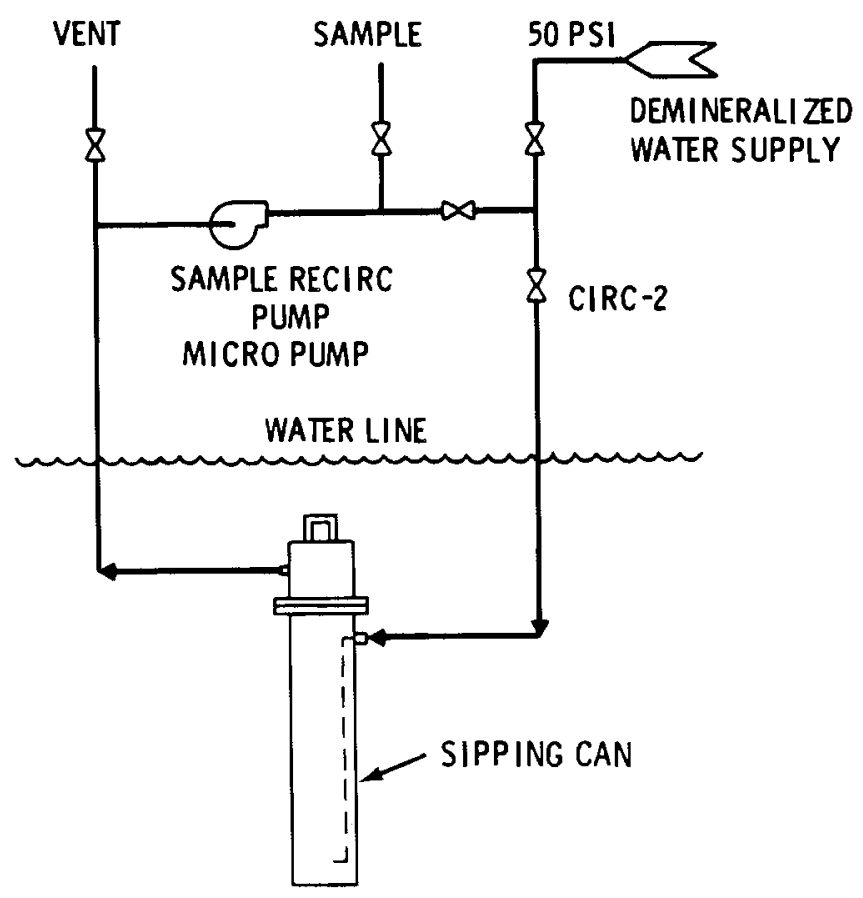

FIGURE 3. Schematic Diagram of Out-of-Core Wet Sipping of BWR Fuel Bundles 
extended time period. In some cases, the contained water is recirculated (mechanically mixed) during the soak period to build up the inventory of fission products, which results in an increase in leak detection sensitivity. At the end of the soak period, the representative water sample is taken. In other cases, the contained water is not mechanically mixed during the soak period but is pumped for a short time $(\sim 3 \mathrm{~min})$ through the fuel bundle before the representative water sample is taken. Water samples are typically radiochemically analyzed to determine the presence and magnitude of specific fission products.

Out-of-core wet sipping has an advantage: the crud layers on the fuel bundles may contain significant quantities of the nuclide of interest (Green 1978b), but the concentrations of that nuclide can vary substantially. This can cause considerable scatter in the background concentrations for sound fuel bundles, resulting in reexamination of a significant fraction of those fuel bundles whose integrity was questioned initially.

Wet sipping at a BWR has a primary advantage since the technique can be applied without the removal of the fuel bundles from the core. In-core wet sipping is not possible at PWRs (Green 1978b).

In-core wet sipping is typically associated with BWRs, and multiple fuel bundles (with channels in place) are sipped simultaneously. This is done by placing a sampler (also known as a sipper head or hood) over the fuel bundles to be tested.

Typical in-core wet sipping equipment used for domestic BWR fuel is shown in Figure 4. The sampler tests four bundles in situ; fuel bundles are not moved, and the channels are not removed from the fuel bundles. The fuel channel and sampler isolate the individual fuel bundles. At some foreign BWRs, up to eight fuel bundles are wet-sipped simultaneously (IAEA 1978).

In the case of in-core wet sipping, after the sample is in place, the soak period is initiated by interrupting the natural circulation of reactor primary coolant surrounding each of the fuel bundles to be sipped. Compressed air is used to stagnate the water and to lower its level in the sampler to the top of 


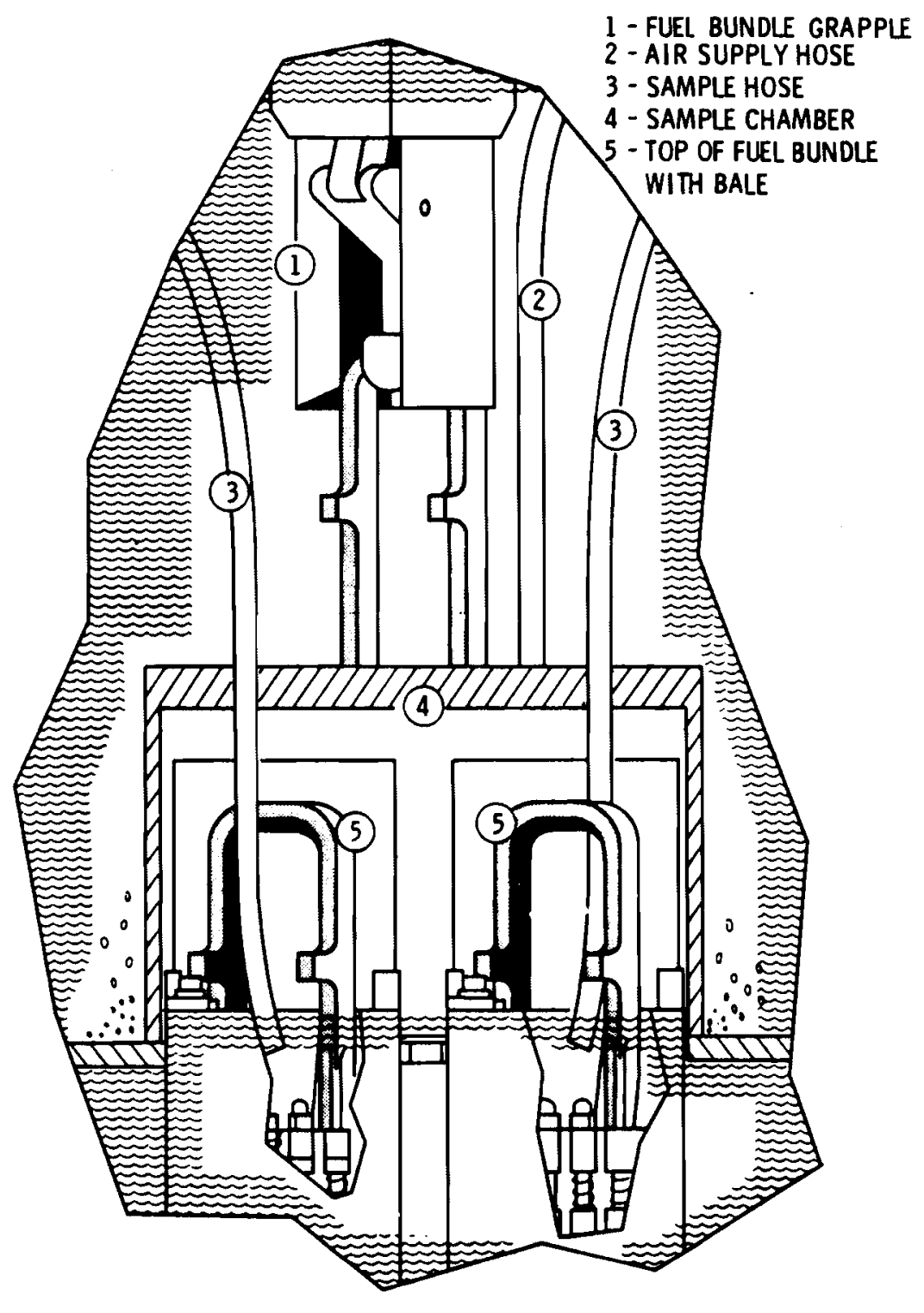

FIGURE 4. Cross Section of a Typical Sampler Used for In-Core Wet Sipping of BWR Fuel

the fuel bundles. Water samples (e.g., from each of the four channels) are taken at the end of the soak period and radiochemically analyzed.

Green (1978b) notes two disadvantages with in-core sipping at BWRs:

1) the concentration of fission products is reduced because of convection currents (a result of having the fuel channel open at the bottom end), and 2) sometimes there are high background radiation levels in the coolant surrounding sound fuel bundles. 
The utility may set the sipping criteria; however, the fuel vendor may decide what constitutes a leaking fuel element (leaker). A great deal of judgment is involved in defining what constitutes a leaker: the level for classifying a fuel bundle as a leaker is usually 10 times lower than that in the contract warranty.

The criteria used for discriminating between intact, suspect, and defective fuel bundles vary among companies. In general, the sorting criteria can involve a number times background or a number of standard deviations above the mean (Green 1978b; French 1975; Madgett 1975; Ogawa et al. 1973). As noted earlier, the background may vary; hence, the criteria are not static. Examples of the criteria that have been or are currently used follow.

At one BWR nuclear power station, a normal activity level (i.e., a background level in relation to leaking fuel) is established by the utility. A fuel bundle is suspected to be a leaker if the count rate of a sample from the sipping system is three times that of the background. Leaking fuel bundles usually produce activities about 3 to 10 times this normal level. With outof-core wet sipping of BWR fuel, past experience reported by a fuel vendor has indicated that activity ratios of 5 to 10 times background are a reliable indication of a leaking fuel bundle (Ogawa et al. 1973).

With out-of-core wet sipping at one PWR in 1975 through 1976, a fuel bundle was considered to contain failed fuel rods if it had two or three of the isotopic concentrations above the three-sigma level (i.e., three standard deviations above the mean) unless resipping demonstrated that the measured activities were due to contamination of the sipping can or sample (French 1975). For all fuel bundles sipped as of June 1977 at one nuclear power station with PWRs, bundles with iodine-131 activities greater than $10^{-2}{ }_{\mu \mathrm{Ci}} / \mathrm{ml}$ were classed as leakers (Zach and Kurtz 1977). Cesium activity was also high with such fuel. Sipped fuel bundles with iodine-131 activities below $2 \times$ $10^{-3}{ }_{\mu \mathrm{Ci}} / \mathrm{ml}$ were classified as nonleakers. Sipped fuel bundles with activities between those two values were classified as "questionable" leakers. 
In-core wet sipping at a foreign BWR indicated that the sipping test is a relative measurement of the sample activity in comparison to the average or background; hence, a 1973 paper stated that no clear-cut boundary exists between sound, marginal, and defective fuel bundles (IAEA 1974d). Major defects, which were most likely hydride blisters (visual inspection was not performed), were believed to be present in 19 fuel bundles that had iodine-132 sip signals that were a factor of five higher than background.

\section{Experience Survey}

Sipping techniques currently in use at domestic LWRs are compared in Table 7. Additional information on the characteristics of those sipping techniques is included in Table 8. Information on sipping may also be found in these references: Peterson 1966; IAEA 1974b; Lang and Lindbeck 1967; Sewel1 1975; IAEA 1978; Green 1978a; MCClintock and Vizzini 1972; Zach and Kurtz 1977; Osborne 1977; Wachter and Lee 1976; Combustion Engineering 1975; Combustion Engineering 1976; French 1975; Duvall and Negin 1967; IAEA 1974d; Madgett 1975; Sundstrand Energy Systems 1977; PaR Systems Corp. 1978; IAEA 1974e; Klein 1966; Madgett 1977; Ogawa et al. 1973; Eickelpasch et al. 1975; IAEA 1974a; Autio 1978; Consumers Power Company 1966a and b; Eickelpasch et al. 1974; Schroeder 1969.

Sipping is typically done by the utility. Sipping is the primary means of detecting leaking fuel bundles for one fuel vendor. Another fuel vendor relies heavily on sipping for initial detection of fuel rod failures but relies on measurement techniques other than sipping for determining fuel performance.

At BWRs, sipping tends to be widely used in a routine fashion. In $90 \%$ of the outages, only sipping is performed. Sometimes utilities do not sip if the fuel vendor feels that the probability of leakers being present is low. The vendor is only in the position to make sipping recommendations; the utility makes the decisions and considers critical path constraints as very strong factors. In-core sipping has always been a critical path item for a BWR 
TABLE 7. Comparison of Sipping Techniques Offered or Employed by Fuel Vendors and Utilities That Were Visited by NRC and PNL. (Bailey et al. 1980b)

Company Sipping Technique Company A offers a sipping system of its own
design as NSSS option. $(\mathrm{d})$

Company $A$ has purchased a two-can system(b) from Company I to provide portability; the intent is to offer sipping services to utilities with PWR fuel. Th is out-of-core system permits leak detection by both wet sipping and hybrid sipping.

B Company $B$ offers in-core dry sipping system option to the utilities. This system involves one sip-)

Company $B$ has developed their own equipment for out-of-core wet sipping. (e) Three cans may be used. They could possibly add one more can but are $i$ imited by the fuel handling capability.

C Company $C$ does no sipping themselves. When Com-
pany C's fuel is sipped, the utility does it. $(h)$

D The utility is responsible for sipping (and it owns the data) and for sipping equipment and procedures. Company $D$ offers sipping equipment, cial basis. The minimum capability for sipping at each BWR is one four-bundle heat for in-core sipping(j) and one can for out-of-core sipping. The sjpping techniques (including time est $i$ -

cribed by Company $D$ are:

In-core wet sipping (old design)(1)

In-core wet sipping (new design)(0)

\begin{tabular}{lc} 
Typical Rate & $\begin{array}{c}\text { Approximate } \\
\text { Leaker } \\
\text { Detection } \\
\text { No. of Fuel } \\
\text { Bundles/Day }\end{array}$ Efficiency \\
\hline
\end{tabular}

$90-95 \%$

$227(f)$

$\operatorname{high}(g)$

1) $>85 \%$

$120-190^{(m)}$

$60-80 \%(n)$

power

shutdown

2) Sipping

starts

3-8 days

after

shutdown

1) Sipping st arts

$120-190$

with in

(with one

23 weeks

$\begin{array}{ll}\text { after } & \text { (with four } \\ \text { shutdown heads) }(m, p)\end{array}$

2150-500

2) There

leakers
Comments

(a) Several plants have one, but only the one at one PWR has been thoroughly checked out. None have been used to actually leak test fuel.

(b) As of the date of the visit, Company A had not yet used this system.

(c) Company 1 indicates that a five-can system is faster than the two-can or threecan system for PWRs; using a five-can system, a sipping rate of 40-60 fuel bundles per 24-hour day is possible depending on reactor plant equipment operating restrictions.

(d) Some utilities have taken this option and have the in-core dry sipping capability.

(e) The spent fuel pool bridge crane is required for the movement of the fuel bundles. Current sipping time constraints are not due to sipping equipment but are due to fuel handling requirements. With Company B's sipping concept, it is possible that sipping could be done over a standard fuel rack position. New high density fuel storage racks may present some additional mechanical interface problems.

(f) In two publicly available reports, it appears that 229 PWR fuel bundles were sipped (217 sipped, 12 resipped) in 204 hours. Company B said foreign plants can sip faster than U.S. plants because they don't have to verify each fuel move.

(g) Company B's sipping is based on a foreign company's experience. That foreign company assumes an efficiency of over $99 \%$ for out-of-core wet sipping of PWR fuel and also indicates that the efficiency for in-core wet wipping of BWR fuel is less than that because of the lower heating in the BWR sipping test.

(h) Company C's fuel has been sipped at four BWRs and three PWRs. Company C's fuel at another PWR has not been sipped because the coolant acitivity has been extremely low. One BWR was the only site where Company $C$ encountered crud release during sipping. That release of crud reduced visibility in the pool to $20.5 \mathrm{~m}$. 


\section{TABLE 7. (contd)}

Company

Sipping Technique

\begin{abstract}
Out-of-core wet sipping
\end{abstract}
Out-of-core vacuum pressure differential (gas) sipping( $q)$, with the sipping container located in a control rod blade storace rack; however. the equipment is also designed for use on the reactor vessel guide rods at BWRs.

Out-of-core dry (gas) sipping $(r)$

$E$ Company $E$ is currently evaluating an updated version of a sipping system. $(s)$

Company $E$ reported in 1972 that its portable sys-

tem for fuel evaluation was normally used away from the reactor containment vessel i.e., the out-of-core sipping was done in the spent fuel pool ; however, the leakdetection portion of the system could be installed in the vessel if necessary. The leak detection equipment associated with the portable system is capable of using three techniques: wet sipping, dry sipping, anc hybrid sipping. Hybrid (combination wet/dry) method is normally used.

$F \quad$ Company $F$ started with in-core sipping and then went to out-of-core wet sipping at one site with BWRs. Company $F$ has not done in-core sipping
since about 1973.(u)

Company $F$ has their own sipping equipment, which consists of a six-station system made by Company $J$. The system is manually operated through a control console (fluid actuators). ( $x$ ) Company $F$ is working with Company $\mathrm{J}$ to develop better sipping hardware and is trying to upgrade the sipping equipment and still hold the cost down.

Dry sipping was performed at one BWR by Company $F$ in 1965 .

55-7g(V)* Company $F$ considers the eff $i$ ciency to be $<50 \%$ for in-core sipping and $90 \%$ for out of-core $(w)$
Requirement Bundles/Day Efficiency

There

concen-

trations
of radio-

active

products

None

$40-60(1)$

$>95 \%$

$>95 \%$ (i) All of Company D's fuel bundles are sipped after the poolside examinations are completed. Generally, every irradiated fuel bundle that is to go hack into the core is sipped (hence, sipping could be on the critical path).

(j) In-core sipping has always been (and still is) a critical path item for the reactor outage. Company $D$ indicated that the most overseas utilities use in-core wet sipping methods.

(k) The following est imates were given by Company $D$ on the time to complete sipping of a full core of fuel bundles this could presumably mean up to 764 by three techniques: in-core sipping, 8 days; out-ofcore sippina, 3 to 4 weeks, and pressure differential sipping, 6 to 8 days.

(1) Used in second and third generation type BWR plants.

(m) Assumes a 24-hour work day.

(n) The approximate leaker detection efficiency is sometimes better or worse than this.

(o) In-core wet sipping by the newly designed technique has indicated the highest leaker detection efficiency and will be Company D's first choice when recommending a sipping technique. It also involves no moving of fuel bundles.

(p) Can be used in sixth generation type BWR plants.

(q) Company $D$ has patented vacuum sipping, a method that yields the high (hence sensitive) signals produced by dry sipping but with the inherent safety of wet sipping (i.e., the fuel bundle remains covered with water). This technique is rapidly becoming the preferred sipping method at BWRs; it has been commercially applied at some domest ic BWRs. The equipment is fully automated, which decreases manpower needs and personnel exposure and provides potential for significantly reducing the critical-path out age time needed for detection of leakers. Because an on-line detector is used in vacuum sipping, data analysis is simplified in comparison to that with wet sipping techniques.

* Rate may be as low as $2193 / 14=214$ bundles/day. 
TABLE 7. (contd)

Company

Fuel has not been sipped by Company $G$ at one PWR. That PWR does not have the equipment to perform

detailed inspections of fuel at a poolside setup.

H Company $H$ has never made plans to sip any fuel at one PWR and possesses no inspection equipment

* Rate may be $550 /(7$ to 10$)=55$ to 79 bundles/day.

\section{Typical Rate} No. of Fuel

Requirement
Approximate

Leaker

Efficiency
Comments

(r) Out-of-core dry sipping is not recommended by Company $D$ for two reasons: (1) cost-extra equipment is needed and Company does not think it is just if ied--and (2) data acquisition and interpretation difficulties (note that no leaker detec-

(s) Company $F$ has used a leak tester but does not rout inely use it because, based on coolant activity, there is no need to leak test.

(t) Company E said that leak testing (sipping) is slow, laborious, and very time consuming. If one had to leak test all the fuel from a PWR this could presumably mean up to 193 fuel bundles, it could add up to two weeks to an outage.

(u) Company $F$ doesn't do in-core sipping at one site with BWRs for two reasons: incore sipping is less effective than outof-core sipping in ident ifying leaky fue 1 , and (2) the whole core is usually taken to unload the core)

(v) Company $F$ indicated it would take 7-10 days to sip 550 fuel bundles (assumes using six cans and doing some resipping). They use 8- and 10-hr shifts and expect to sip 40-50 fuel bundles per shift.

(w) Company $F$ says sipping effectiveness depends on the power history of the core.

$(x)$ The present system is simpler than the previous one used by Company $F$ at one site with BWRS and reduces operator exposure because there are no valves to be manually operated. There are no automatic timers; timing and sipping sequence are manually controlled. With equal soak and count time intervals, opt imum equipment usage is obtained.

(y) No plans to sip fuel were made because the levels of radioactivity in the effluent during reactor operation have been low. 
TABLE 8. Comparison of Characteristics of Sipping Systems in Current Use(a) (Bailey et al. 1980b)

\begin{tabular}{|c|c|c|c|c|c|c|c|c|}
\hline Company & $\begin{array}{l}\text { Sipping } \\
\text { Technique }\end{array}$ & $\begin{array}{l}\text { Bot tom of } \\
\text { I solating } \\
\text { Container } \\
\text { (Can or } \\
\text { BWR Channel) }\end{array}$ & $\begin{array}{l}\text { Type of Seal } \\
\text { at Top of } \\
\text { Container } \\
\end{array}$ & $\begin{array}{c}\text { How is Contained } \\
\text { Cont aminated Water } \\
\text { (Spent Fuel Pool Water or } \\
\text { Primary Coolant) Displaced }\end{array}$ & Soak Period & $\begin{array}{l}\text { Is Contained } \\
\text { Water } \\
\text { Recirculated }\end{array}$ & $\begin{array}{l}\text { Volume of } \\
\text { Sample }(s)\end{array}$ & $\begin{array}{l}\text { Water and/or Gas Sample } \\
\text { Analys is and Comments }\end{array}$ \\
\hline A & $\begin{array}{l}\text { This company offers } \\
\text { a sipping system of } \\
\text { own desjgg as NSSS } \\
\text { opt ion. (b) }\end{array}$ & & & & & & & \\
\hline A & Out-of-core wet and & & & & Maybe $1 \mathrm{hr}$ & & & \\
\hline
\end{tabular}

Out-of-core wet and (using a Company I

B Out-of-core wet sipping
Can bottom Inflatible Pool water is used for seal (pneu- sipping mat ic system$$
\text { used to }
$$
close lid
and inflate
seal).
Two water sam- Ge( $L i)$ detector used;
les, $250 \mathrm{ml}$ each water sample analyzed for 3 isotopes, one of which is iodine-131. One water sample is

B In-core dry sip-

C Th is company does no sipping themselves at reactor sites. (b)

D In-core wet sippin (four hut sipping Channel bot(four hund ses sip- tom not

A "sipper Air used to lower conhead" that tained primary cool
fits over a top of fuel bundle. four-bundle cell is used.

Out-of-core wet Enclosed can sipping

Out-of-core vacuum sipping (pressure sipping) at BWRs; however, th is
Forced circulation flushing with demineralized water is used

230-60 min (typically $60 \mathrm{~min}$; however, $45 \mathrm{~min}$ use at some plants and one plant used $30 \mathrm{~min}$

Can flushed with demineralized or reclaimed (condensate) water and air ground. Then level of
23-10 $\mathrm{min}$ soak peri- is employed soak perisysten is
Mechanical One-liter water mixing (pump- sample taken. decay heat $200 \mathrm{ml}$ is used used to ther- for analysis. mally mix the cont a ined coolant. Mechanical

One- 1

iter water ple

Gaseous activity (i.e. krypton- 85 xenon-133, sured with an on-line sured with an on-line
Water sample processed radiochemically (gamma iodine-131 (considered as primary indicator of leakers) and iodine -132 . and ces ium-137 is op$t$ ional (cesium considered as secondary ind $i$ is not rout inely done.)

Water sample processed scan) for iod ine-131, cesium-134, and cesium137. 
TABLE 8. (contd)

\begin{tabular}{|c|c|c|c|c|c|}
\hline Company & $\begin{array}{c}\text { Sipping } \\
\text { Technique }\end{array}$ & $\begin{array}{l}\text { Bot tom of } \\
\text { I solat ing } \\
\text { Container } \\
\text { (Can or } \\
\text { BHR Channel) } \\
\end{array}$ & $\begin{array}{l}\text { Type of Seal } \\
\text { at Top of } \\
\text { Container }\end{array}$ & $\begin{array}{c}\text { How is Contained } \\
\text { Cont aminated Watter } \\
\text { (Spent Fuel Pool water or } \\
\text { Primary Coolant) Displaced }\end{array}$ & Soak Period \\
\hline & $\begin{array}{l}\text { equipment has been } \\
\text { designed to a lisn be } \\
\text { used on the reactor } \\
\text { vessel guide rods } \\
\text { at BWRs. }\end{array}$ & & & $\begin{array}{l}\text { contained water is lowered } \\
\text { with air to top of fuel } \\
\text { bundle }\end{array}$ & $\begin{array}{l}\text { reduced in } \\
\text { pressure by } \\
\text { drawing a } \\
\text { partial } \\
\text { vacuum } \\
\text { over the } \\
\text { air/water } \\
\text { interfacel }\end{array}$ \\
\hline D & $\begin{array}{l}\text { Out-of-core Ary } \\
\text { sipp ing (this com- } \\
\text { pany does not } \\
\text { recormend this } \\
\text { techn ique; } \\
\text { however, it is } \\
\text { present iy used at } \\
\text { three small BWRs). }\end{array}$ & & & $\begin{array}{l}\text { At one BWR, the water is } \\
\text { exhausted from the can } \\
\text { by pressurized air. }\end{array}$ & $\begin{array}{l}\text { One BWR } \\
\text { uses } 20 \\
\text { min for } \\
\text { early dis- } \\
\text { charqes and } \\
\text { to around } \\
45 \text { min for } \\
\text { the last } \\
\text { fuel bun- } \\
\text { fles tested. }\end{array}$ \\
\hline
\end{tabular}

E Updated version of a sipping system is

E Out-of-core wet, dry or hytrid sipping (using the leak detection sys tem that is a part of a portable fuel inspection system) has been used in past; ( 0 ) if necperform these in side reactor containment vessel. Hytrid (comb ination wet/dry)method is normally used.

F out-of-core wet sipping (using a
Company J system)
When hybrid sipoing, pool $30 \mathrm{~min}$ water forced from leak test chamber by nitrogen chamher is then immedi- ately backfilled with de-
mineralized water. A mineralized water. A back ground water sample is obtained from inside in chamber is then lowered to top of fuel bundle: then nitrogen pressure above fuel bundle is reduced. Is Contained Water Volume of tector. It has detector. Krypton 85 detector. during develop- primary indicator of ment work on this leakers. If the fue? technique that bundle has had a long arab samples of decay time (i.e., years water are siani- after heing discharged ficantly enhanced from reactor core), the by the partial qas sample is only examined for krypton-85.

At one BWR, a CP monitor claced next to the char coal trap of the sippin diate qualitative indication of fuel bundle condition. Analysis of the aas sample, however, yields the quant itative and $f$ inal classification
of all the tests.

Can is flushed for $15 \mathrm{~min}$ with dimineralized water. soak $t$ ime is $20 \mathrm{~min}$

One-piter water sample
The gas sample is collected by purging gas sample container. The lyzed for iodine isotopes.

water is
added to

chamber in

area above

and recircu-

lated: then

lated; then

water samp
is taken.
A CP is used to ini- tially check the sam- ples to get a general associated with leaky associated with leaky samples are checked first, then filtered samples (the millipore




\section{TABLE 8. (contd)}

Sipping
Technique

Bot tom of

Type of Seal How is Contained

(Can or at Top of (Spent Fuel Pool Water or

Primary Coolant) Displaced
Piter

\author{
Is Contained
Water \\ Water
} Volume of
Sample(s)
Water and/or Gas Sample Analys is and Commerts

checked. A Ge(Li) de-

tector and a mult ichan-

nel analyzer are used to
analyze the water sample

analyze the water sample
ple for iodine-131 and

ple for iodine-131 and
ces ium-137. Ind ine-131

is their primary sipping

is their primary sipping
isotope but has a short

lifetime, makina it nec-

essary for them to look

for their secondary sip-

ping isotope, cesium-

137. In some cases,

however, cesium-137 is
more sensitive than

more sensitive than

lodine-131 in ident if y-
ina leaky fuel and thus

will he used as the pri-

mary isotope. Usualiy,

lowed, al though Company

$F$ bas been encouraged by Company $D$ to look at a number of isotopes.

Spent fuel ponl water

samples are taken once

per 8-hr shift and ana-

lyzed to determine back-

ground activity changes.

After analytical results

are obtained, the opera-

water samples.

G Fuel has not been sipped by this company at this PWR because no fuel problems have been experienced in any of the associated fuel cycles.

H Activity levels have been low; hence, no plans for made yet $f$ or this PWR by th is com-

(a) The characteristics shown came from discussions during NRC-PNL visits to five fuel vendors and three reactor sites and from associated literature sources.

(b) See Table 7 for additional details. 
outage. Because of critical path constraints and if operating effluent radioactivity levels are low, even sipping may not be performed during an outage.

At PWRs, the tendency is for sipping to be used only if necessary, and some PWRs currently have no plans to conduct sipping. Sipping is not routinely conducted at certain PWRs because, based on coolant activity, several fuel vendors and utilities feel that there is no need to leak-test the fuel bundles.

\section{EDDY CURRENT TESTING}

Nondestructive testing by electromagnetic methods involves inducing electric currents (eddy currents) in a metal test object (such as the capsule or Zircaloy fuel rod cladding) and electronically measuring the changes produced when the eddy currents are altered by inhomogeneities in the test object. These inhomogeneities can be of a physical nature such as a crack, pit, lap, or dimensional variation, or can be a result of process differences such as heat treatment, hardness, and chemical composition. Eddy-current testing is a nondestructive method used to characterize metals containing these inhomogene ities. Metals containing unwanted defects can be quickly sorted out, enabling the manufacture of quality products. Eddy-current testing is one nondestructive method industrially used to inspect, detect, characterize, and assess the integrity of nuclear fuel rods.

Single-phase eddy current testing is described here since it is currently commonly used for this type of service. Multiple-phase eddy current testing is a newer and potentially more flexible technique that may be investigated and developed for the application considered in this study.

Principles of Eddy Current Testing

During some refueling outages at reactor sites, fuel rods are examined under water using the eddy-current inspection technique. An eddy-current inspection probe encircles the fuel rod, positioned in a test fixture as shown 
in Figure 5. The inspection probe, called an encircling coil probe, is composed of many wires wound around a nonconducting disk with a hole in the center into which the fuel rod fits.

An eddy-current instrument is used to energize the search coils (i.e., the conducting wire coils) of the probe, which causes a magnetic field coupling to exist between the search coils and Zircaloy fuel rod cladding. The alternating magnetic field induces eddy currents to flow circumferentially around the metal wall. The eddy currents in turn induce a secondary voltage in the search coils that can be used to interpret wall parameters. If defects are present in the wall, this will cause a perturbation in the normal flow of eddy currents in the wall, which results in a change in the induced voltage in the search coils. The defect signal is detected and processed electronically and is typically displayed on a strip-chart recorder.

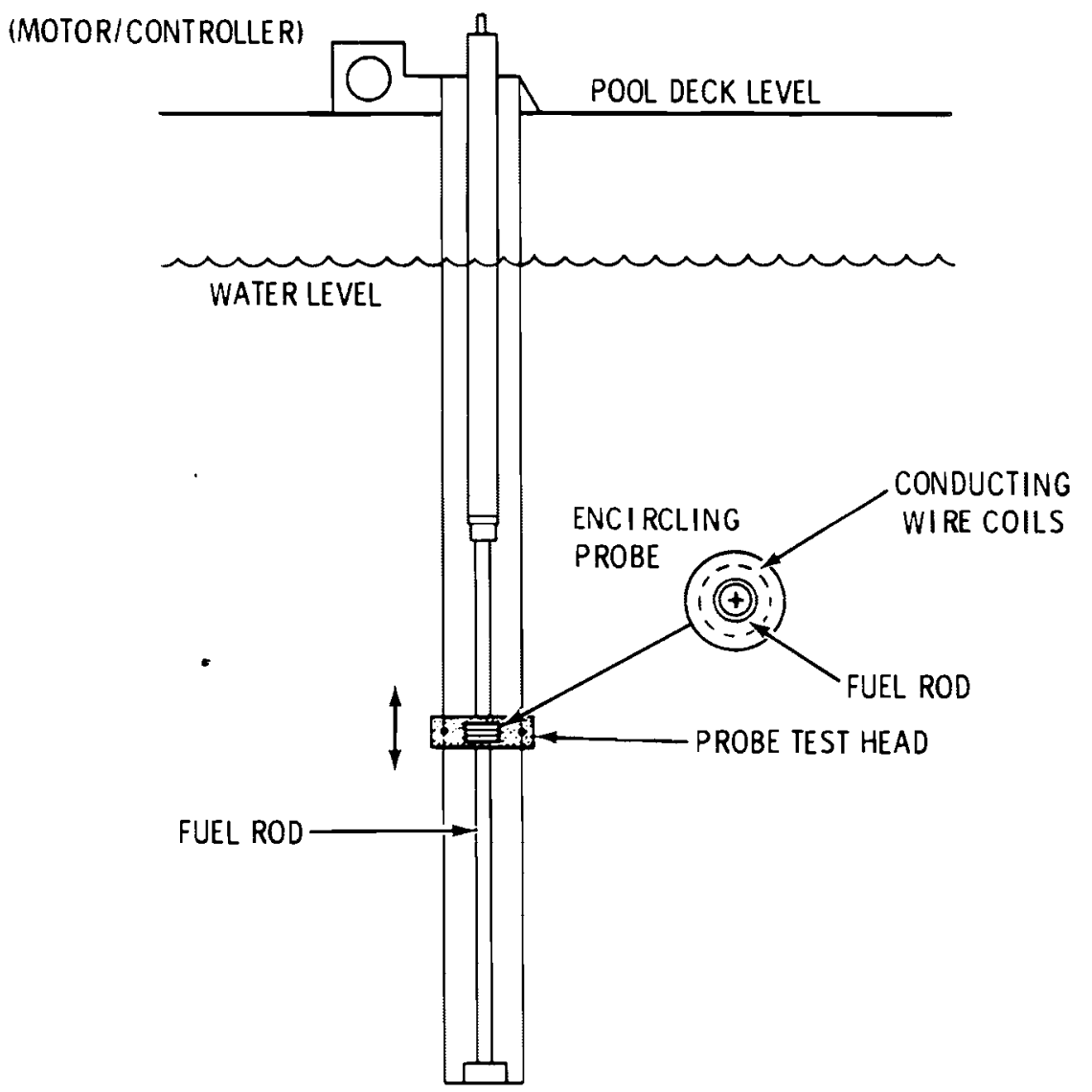

FlGURE 5. Eddy-Current Inspection at the Spent Fuel Storage Pool 
Skilled inspection personnel interpret the eddy-current inspection data and, from their analysis, classify each fuel rod according to its defect condition.

Description of Eddy Current Testing

Eddy-current test systems vary in complexity. They can be simple or complex, and depend on inspection requirements. However, whether simple or complex, eddy-current test systems must be capable of providing three major functions. These functions include: 1) the generation and detection of eddy currents, 2) electronic processing of the detected eddy-current signal information, and 3) recording and display of the eddy-current data in a usable form. The eddy-current test system is composed of three subsystems as shown in the block diagram in Figure 6 . Test systems used for inspection of Zircaloy cladding of fuel rods are similar in design and operation.

\section{Eddy-Current System Components}

The major subsystems of an eddy-current test system are discussed below. Inspection Probes. Key to the inspection and detection process is the design of the inspection probe. The inspection probe is the link between the electromagnetic test system and test object. All the electromagnetic information about the test object is obtained by the inspection probe. The probe used for the inspection of fuel-rod cladding is called a differentially wound encircling coil probe and is shown in Figure 7. Two coils (test coil $A$ and $B$ ) are connected in series and are wound around an open-core nonconducting material. The narrow coils are closely spaced. Insertion of a fuel rod into the open

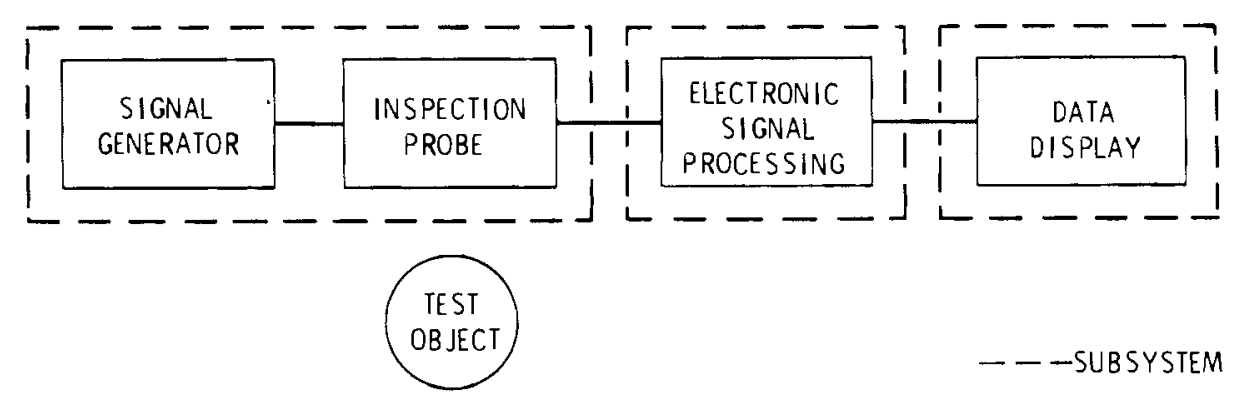

FIGURE 6. Block Diagram of Eddy-Current Test System 

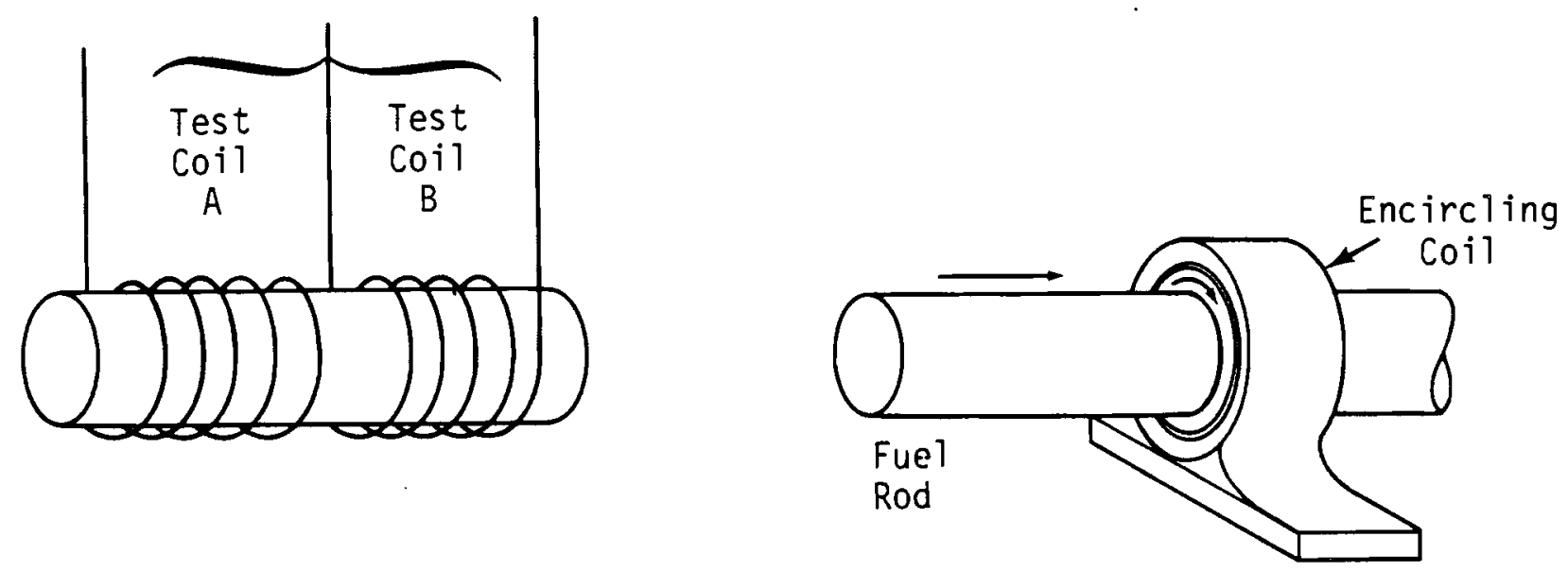

FIGURE 7. Differential Encircling Coil Probe

core of the differential encircling coil will cause a change (modulation) in the magnetic field of the coils.

In order to achieve high sensitivity for the detection of small flaws in fuel-rod cladding, it is necessary to electronically balance (null) the impedance of test coil A and test coil B (i.e., the current amplitude and phase must be equal). In order to achieve this impedance match, a wheatstone bridge circuit or other type of null balance device is used. The wheatstone bridge circuit is shown in Figure 8 (Davis 1977) and is simply composed of amplitude and phase adjustment potentiometers connected in parallel with the test coils. Changes common to both coils or gradual changes in the electrical (or magnetic) properties of the cladding may not produce a detectable signal.

There are advantages and disadvantages when using encircling coil probes. The advantages are: a) the probe has the ability to inspect the entire circumference of the cladding (100\% volumetric inspection), b) probe geometry lends itself to high speed inspection of tubular shaped products, c) probes can be constructed to have good durability, d) probes are generally small and compact, and e) probes are not affected by high radiation exposure levels. Some disadvantages are: a) the inability to detect small defects (e.g., incipient cracks) as a result of the particular characteristics and/or 


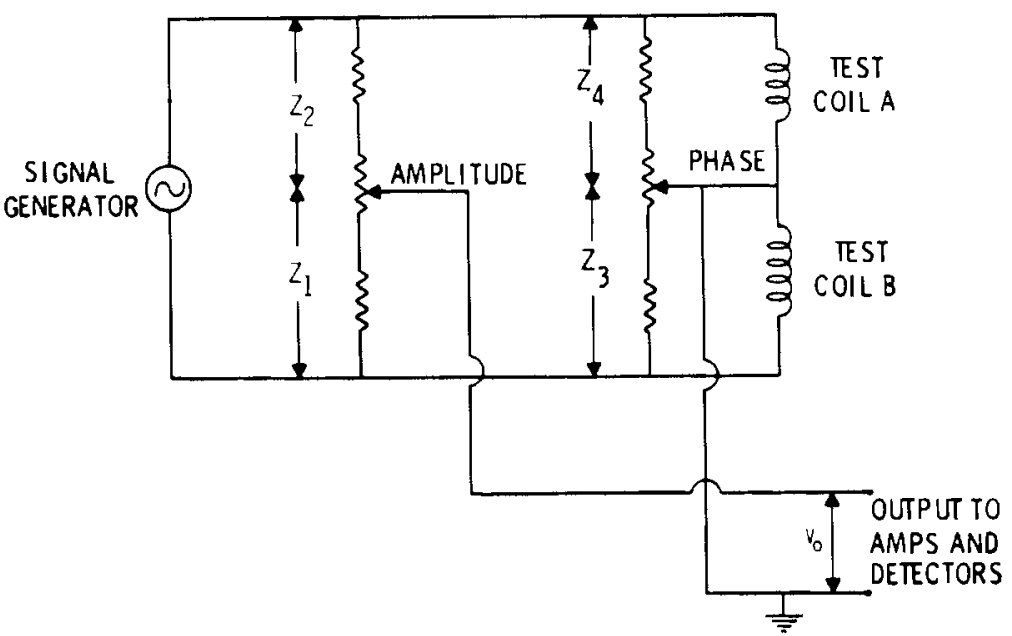

FIGURE 8. Eddy-Current System Wheatstone Bridge Circuit (Davis 1977)

orientation of these defects; b) inability to locate the circumferential position of a defect on the cladding (thus, to pinpoint a defect, a surface point probe having a small localized magnetic field, would be required); and $c$ ) the response to changes in conductivity, permeability, fill factor, and dimensional variations (e.g., diametrical shrinkage or ridging). The system response to variables that are not of interest may be greater than the response produced by the variable of interest. Specifically, the signal response the result of cladding ridging (bambooing) may produce a stronger eddy-current signal indication that a small incipient crack.

Signal Processing. Basically, the signal processing system is composed of an amplifier, phase-sensitive amplitude detectors, and a phase rotator. The phase rotator is used to adjust (rotate) the detector output signals in order to properly display the information on the readout equipment.

Data Recording and Display. Dual-channel strip-chart recorders, reel-toreel or cassette magnetic tape recorders, and oscilloscope display are all used by fuel vendors to record and display eddy-current data. The dual-channel strip-chart recorders are used in real time to record the in-phase and quadrature amplitude data. Magnetic tape recorders using reel-to-reel or cassette tape are used as a convenient means of recording eddy-current inspection data for postinspection analysis. 
Eddy-Current Inspection at the Spent Fuel Storage Pool. Eddy-current testing of fuel rods is one nondestructive testing method used to locate suspect or leaker fuel rods in fuel bundles that have previously been identified as suspects or leakers by other inspection techniques (e.g., by sipping). Single-frequency, continuous wave excitation, eddy-current systems are currently used for poolside fuel-rod inspection. Eddy-current testing lends itself to the requirements of inspection speed, reliability, and detection sensitivity.

Two major causes of fuel failure have been internal hydriding of the cladding resulting from moisture in fuel, and pellet-cladding interaction. Eddy-current testing has been used in both cases to help locate and characterize the failure mechanisms. In addition, eddy-current testing has been used to study other degradation mechanisms, such as cladding collapse, bulging, fretting and bowing.

Remote Inspection Operations. Because of the high radioactivity of irradiated fuel, eddy-current inspection at poolside requires remote handling equipment. The equipment varies in design and operation, with the objective being the remote handling, disassembly, and reassembly of the fuel bundle so that fuel rods can be removed, inspected by the eddy-current systems, and reinserted (or replaced).

The electronic equipment necessary to perform fuel bundle and fuel rod inspection is located adjacent to the spent fuel pool where the test personnel can visually observe the handling, positioning, and inspection operations. A crane is used to transport fuel bundles in the storage pool. The crane is located above the pool on a roller assembly so that it can tráverse the complete length of the pool. Underwater cameras are used to assist test personnel in the fuel handling and inspection operations. Special tools and fixtures are used to disassemble and reassemble individual fuel bundles. Strict operating procedures are followed when performing fuel inspection operations.

There currently is no poolside eddy-current inspection of fuel rods unless the rods are removed from the fuel bundle. In order for fuel rods to be 
tested using eddy-current inspection, a series of fuel handling, leak test (sipping test), and bundle disassembly operations are required. Fuel bundles suspected of having one or more fuel rods with cladding perforations are first tested for their leak tightness using fuel sipping techniques. Bundles having a high probability of containing failed fuel rods are designated for disassembly so that the fuel rods can undergo additional nondestructive examination. Upon removal, each rod is carefully moved from the bundle disassembly station to the nondestructive inspection test station. The grappled fuel rod is moved at a slow rate that enables the fuel rod to maintain a vertical orientation.

Prior to nondestructive testing, the operator may require that the fuel rods be cleaned. If there is a large amount of crud on the rod, an attempt to clean the rod is made. A set of rotating brushes is used to clean the rods. After cleaning, the fuel rod is positioned and aligned in the inspection test station.

Poolside Eddy-Current Inspection. In order to perform the eddy-current inspection, the fuel rod must be either translated past the encircling coil probe (i.e., probe-fixed) or the probe must be moved past the fuel rod. Figure 9 shows the inspection station of a European vendor with a slide carriage assembly used to translate the encircling coil probe along the fuel rod. Domestic fuel vendors use similar systems where the inspection probes are held in a fixture that traverses the fuel rod.

Supplemental Inspection Techniques at Poolside. Eddy-current testing is used for the total (100\%) volumetric examination of the fuel rod cladding. However, the eddy-current technique is sensitive to changes in a number of parameters, including a) cladding inner and outer diameter surface roughness; b) permeability changes that can result from oxide crud deposits on the clad outer diameter; c) small physical anomalies $(0.025 \mathrm{~mm}$ or 0.001 in.) such as indentations that may be characteristic of the manufacturing process; d) smal1 fretting wear about the spacer grid, which may not be cause for fuel rod rejection; e) cladding ridging (bambooing), a result of irradiation; and f) surface scratching, possibly produced from disassembly and reassembly of 


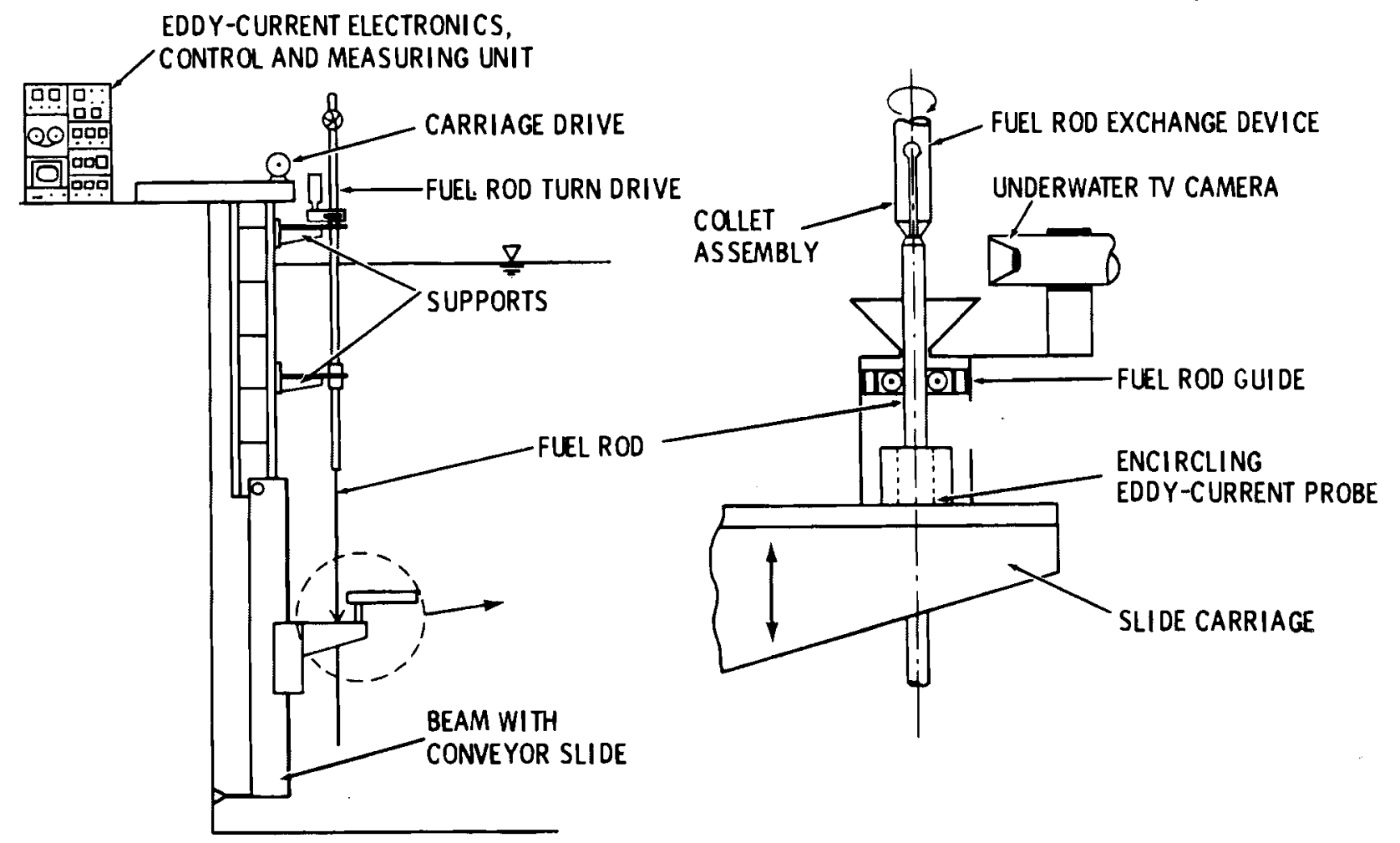

FIGURE 9. Example of Eddy-Current Inspection Station at Poolside (Knaab 1977)

the fuel bundle rod matrix. This list serves to show that the interpretation and evaluation of eddy-current signal information can be a callenging task. An example of eddy-current inspection data from an irradiated fuel rod is shown in Figure 10. Note the strong amplitude signals at the spacer grid area. Also shown is an area that is suspected of containing a defect anomaly.

To help discriminate among some of these influencing variables, supplemental nondestructive examination techniques are used. The more common techniques employed are: a) fuel rod profilometry, b) visual inspection, and c) ultrasonic inspection. Profilometry measures fuel rod diameter changes, such as cladding ridging, using linear variable differential transducers. Thus, diameter changes indicated by the profilometer system should correlate with eddy-current results for cladding ridging. 


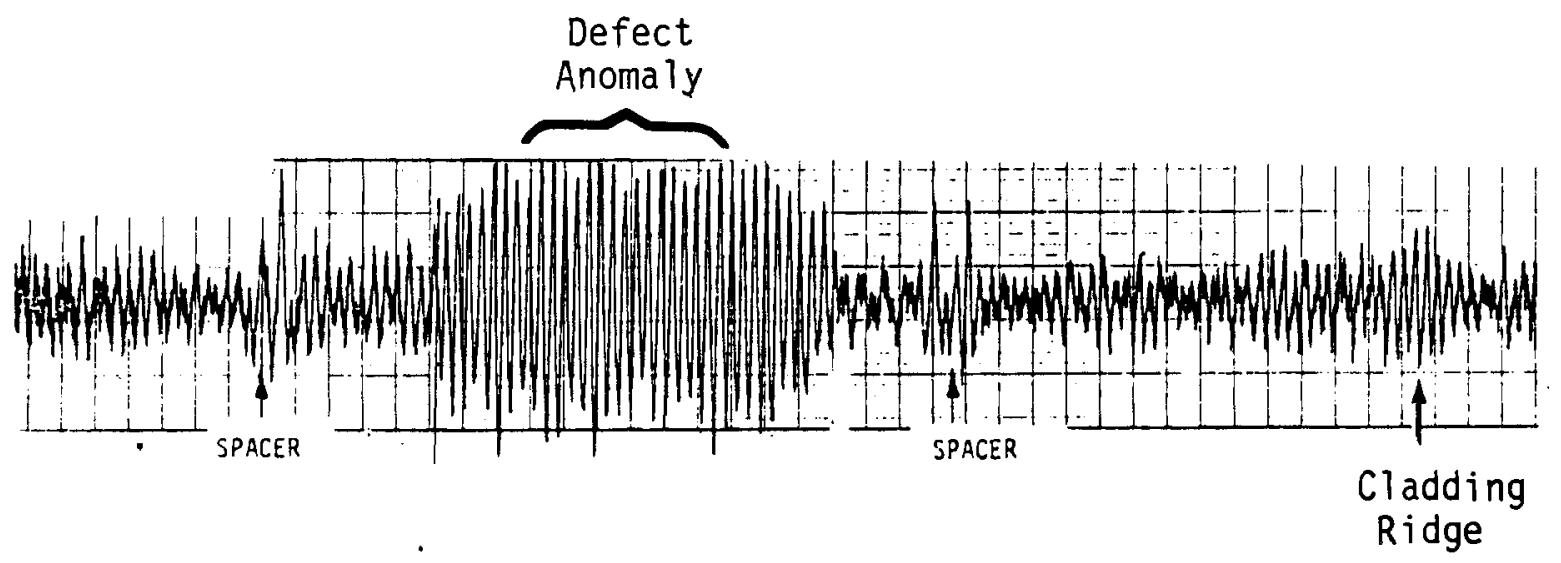

FIGURE 10. Eddy-Current Poolside Inspection Data From an Irradiated Fuel Rod

Visual inspection of irradiated fuel is performed using precision borescope, periscope, and television equipment, and is a simple method for assessing the cladding surface condition. Visual inspection of fuel rods is used to confirm: a) the presence of crud deposits; b) fretting wear in the spacer grid area; c) hydride blistering; d) surface scratching; e) outer-diameter defects; and f) severe ridging, bowing, or other diameter changes. Another important use of visual inspection is in the examination of the fuel rod end-cap weld areas.

Eddy-current inspection is precluded in this area because of the large signal indication resulting from the coil field interaction with the edge of the fuel rod (edge effect).

Eddy-Current Test Standards. Test standards are required in order to establish test system operation and sensitivity. Test standards used at poolside are made using representative fuel rod cladding with artificial defects machined into the cladding. The standard is developed with the intent to contain known artificial defects that produce eddy-current signals that are indicative of real defect signals.

Fuel Rod Acceptance and Rejection Criteria. Eddy-current results, along with ultrasonic and other supplemental test (e.g., visual) results, are compared by the fuel vendor with his acceptance and rejection criteria for irradiated fuel rods. 


\section{Experience Survey}

The eddy-current tests are used to assess the leak-tight integrity of irradiated fuel rods.

Ultrasonic Test Results

One vendor uses ultrasonic inspection to confirm the presence of water in an irradiated fuel rod, which is an indication of loss of fuel rod integrity. Ultrasonic test sensitivity is not affected by the same variables that influence the detection sensitivity of the eddy-current test.

Visual Inspection Results

One vendor stated that there was a high probability of visually confirming the presence of a defect that produced large amplitude eddy-current signal indications. For smaller amplitude indications, there is a low probability (10\%) of visually confirming the presence of the defect(s).

Visual inspection is the principal means of assessing damage in the fuel rod end-cap weld areas because eddy-current testing is not performed in these areas of the fuel rod.

Vendors reported that on limited occasions surface penetrating defects were confirmed by visual inspection; however, the eddy-current test results showed little or no signal indication from these defects. One vendor stated that small pinhole defects were difficult to detect using eddy-current testing. These pinhole defects sometimes emit bubbles that can be detected visually.

\section{Frequency of Eddy-Current Inspection}

Eddy-current testing is not routinely used during fuel surveillance programs. In interviews with the various fuel vendors, it was noted that each fuel surveillance program is unique; therefore, the inspection methods used at one outage may not be selected for use at the next outage. One fuel vendor does not perform eddy-current tests at poolside. Two fuel vendors indicated that they seldom use eddy-current testing at poolside. Finally, another fuel vendor indicated that eddy-current testing was included in the ir fuel 
surveillance programs when it was suspected that fuel failures were present or when lead test bundles were to be inspected to provide data on fuel design.

Table 9 shows the associated total number of fuel rods inspected to date by eddy current testing.

Time and Personnel Requirements

Vendor estimates of the time required to complete an eddy-current test on a single rod ranged from a few minutes to an hour. Vendors stated that often eddy current is not the only test being performed at poolside. In addition to the eddy-current test, visual, dimensional, ultrasonic, and gamma scan measurements can be performed at the same time. The merit of performing several examinations at once minimizes the need to handle and move the fuel rod. If eddy current testing were the only examination being performed on the fuel rod, a complete inspection could be performed in well under $1 \mathrm{~min}$. Vendors indicated that the eddy-current test is a rapid means of volumetrically inspecting fuel rods; however, the time-consuming part of the inspection really involves the bundle disassembly rod extraction, rod reinsertion, movement of the rod to and from the test station, calibration, supplemental inspection, and interpretation of data.

Vendors estimate that it requires two technicians per shift to perform eddy-current testing. During the more detailed fuel surveillance programs, there are a number of technicians and some engineers participating in these programs. The technicians are used in performing the overall fuel inspection program and are not dedicated to performing eddy-current inspection alone.

TABLE 9. Poolside Eddy-Current Inspection of Irradiated LWR Fuel

Type of Fuel Manufactured

Approximate Number of Irradiated Fuel Rods Inspected by EddyCurrent Testing
Data From Fuel Vendors

\begin{tabular}{lllll}
\hline PWR & PWR & PWR/BWR & BWR & PWR \\
-- & $400(\mathrm{a})$ & 500 & 43,000 & Unknown
\end{tabular}

(a) Approximately 200 burnable poison rods also examined. 


\section{Limitations to Eddy-Current Testing}

One limitation of eddy-current testing as practiced at poolside is the lack of sensitivity and reliability for detecting incipient defects. Incipient defects are characteristically very tight cracks that initiate at the cladding internal diameter and can eventually penetrate through the cladding wali. One cause of incipient defects in the cladding is pellet-cladding interaction. Recent studies of this phenomenon involved eddy-current testing at poolside and in the hot cell to detect potential incipient defects. Nondestructive eddy-current and destructive metallographic results from those studies showed that an eddy-current signal is much less likely to indicate cracking than it is to indicate fuel-cladding bonding, pellet fragmentation, and/or cladding ridging.

Several vendors indicated that incipient defects are difficult to detect. They question the reliability of the eddy-current measurement for incipient defect detection because they have destructively sectioned fuel rods with strong eddy-current signals and have not found defects. Another vendor indicated that they had examined $\sim 20$ irradiated fuel rods in an effort to correlate eddy-current signals with the results obtained from metallography. The results of this study showed that there was no defect size correlation.

Vendors stated that analysis of eddy-current data from fuel rods can be difficult because of cladding ridging, fretting about the spacer grid area, scratches, bulging, oxide, and crud deposits. Confirmation by supplemental techniques are needed; this requires additional time and personnel.

The end-cap weld areas on fuel rods çannot be inspected using the present poolside eddy-current techniques. The visual inspection used to inspect those areas requires additional time and personnel.

Poolside Inspection Hazards

Eddy-current inspection does not alter its subject specimen. However, vendors reported that there have been instances when fuel rods have hung up in the encircling coil probe. 
Hot Cell Eddy-Current Inspection Techniques

Nondestructive eddy-current and confirmatory destructive testing of selected fuel rods is performed in hot cells to provide detailed characterization of fuel performance phenomena. The destructive examination data are needed to determine test confidence (detectability, reliability, defect severity, adequacy of standards) and to better understand the often complex fuel degradation mechanisms that nondestructive techniques are attempting to detect and measure.

The eddy-current inspection systems used at hot cells differ from the continuous wave, single-frequency, sinusoid excitation systems used at poolside. Recently published reports from fuel performance programs sponsored by the Electric Power Research Institute show hot cell eddy-current test results from irradiated LWR fuel inspection using a two-frequency, eddy-current system (Pasupathi et a1. 1978; Combustion Engineering 1976; Flora et al. 1977; Rosenbaum 1977). Researchers at Idaho National Engineering Laboratory (INEL) (Yancey 1979) and General Electric Vallecitos Nuclear Center (GEVNC) (Asamoto 1972) reported results of their hot-cell inspection programs for irradiated LWR and breeder reactor fuel using pulse eddy current (PEC) systems. Much of the reported PEC hot cell work to date has been the result of research programs investigating LWR and breeder reactor fuel-rod performance.

\section{Future Eddy-Current Capability}

There appears to be little emphas is by vendors to improve current poolside eddy-current inspection capability. There are several reasons for this. Most vendors use eddy-current inspection on a limited basis. Vendors stated that fuel performance is good and the small fuel failure (leaker) rate is indicative of the good fuel performance. Vendors point out that the reactor system was designed to have some leaker rods in the core during normal plant operation. Present eddy-current testing capabilities have proven to be adequate for detecting leaker rods during poolside inspection. 
Comments on Failed Fuel

Eddy-current testing is the principal nondestructive technique used for the $100 \%$ volumetric inspection of the fuel rod cladding. Strong eddy-current signals on fuel rods between the spacer grid areas are an indication of a possible breached cladding condition. Criteria for accepting and rejecting fuel rods depend on eddy-current and supplemental test results. Fuel rods which are known to have or are suspected of having a breach in the cladding are rejected. Visual inspection is an important supplemental technique for assessing fuel rod damage in the spacer grid areas.

\section{ULTRASONIC TESTING}

Ultrasonic testing is a nondestructive measurement technique used to determine the leak-tight integrity of irradiated fuel rods and to detect suspect failed fuel rods. Two domestic fuel vendors indicated that they had investigated the use of ultrasonic testing in attempts to detect coolant entry into the fuel rod; however, they currently do not use ultrasonic techniques at poolside. Only one domestic fuel vendor uses ultrasonic testing at poolside to detect water with in the fuel rod, an indication that the cladding has been perforated. One foreign company uses an approach similar to that of this domestic fuel vendor; however, their technique involves heating and cooling of the fuel rod. This application is discussed later.

The presence of water within the fuel rod causes a change in the ultrasonic signal amplitude when the water contacts the inner cladding wall surface. One domestic fuel vendor has inspected thousands of fuel rods using this technique and indicated that it has detected leaky fuel-rods. When water is detected in a fuel rod, the rod is categorized as failed (leaker) and is replaced with another fuel rod during reconstitution of the fuel bunde.

Recently, there have been additional applications of ultrasonic testing techniques to poolside inspection. Another of the domestic fuel vendors reported that they had attempted to use ultrasonics to inspect fuel rods for axial defects in the cladding wall. In addition, they have attempted to use ultrasonic testing to determine if fuel pellets were bonded to the cladding. 


\section{Principles of Ultrasonic Testing}

Ultrasound is sound wave energy generated at ultrasonic frequencies (i.e., $>20,000 \mathrm{~Hz}$ ) by the application of a high-voltage pulse to a piezoelectric material. It is through this phenomenon, called the "piezoelectric effect," that electrical energy is converted to mechanical energy (and vice versa) to produce and detect sound waves at high frequencies. The piezoelectric effect has a forward (generation) and reverse (detection) effect. Figure 11 shows an example of the forward piezoelectric effect where a voltage pulse is applied to the piezoelectric crystal (transducer). This sharp voltage pulse causes the piezoelectric crystal to expand and contract from its original thickness. The electric pulse energy has been converted into mechanical sound vibrations as a result of the piezoelectric effect. If the voltage pulses are repeated in rapid and periodic succession, a series of sound waves will be continuously transmitted from the piezoelectric transducer. In order to transmit the sound wave energy into the test material, a liquid (water) provides a couplant path for the sound to travel from the transducer, through the couplant liquid, and

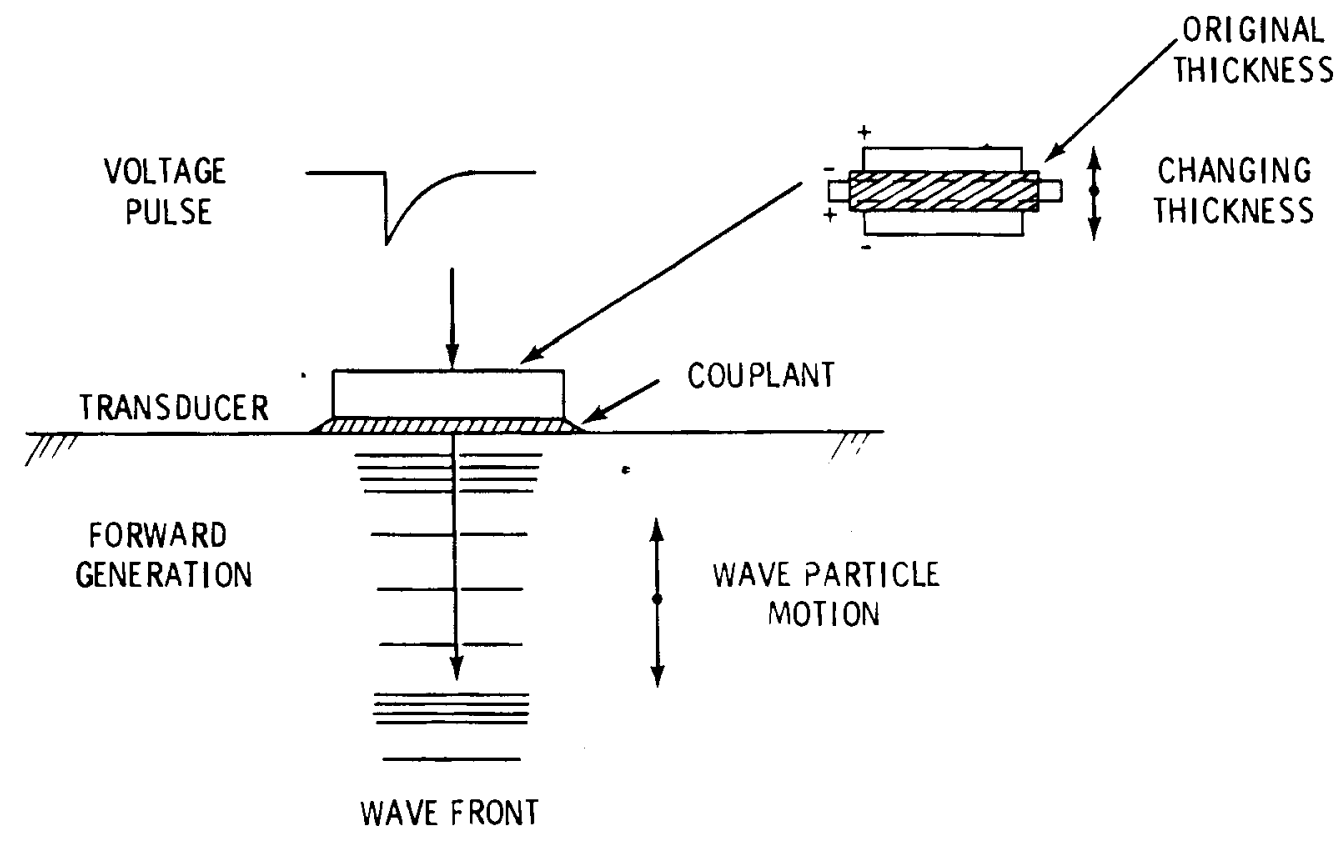

FlGURE 11. Forward Piezoelectric Effect (Electric Signal lnput Mechanical Thickness Change - Acoustic Sound Pressure) 
into the material under test. Liquid couplants are used because of their convenience. The reverse (detection) effect is shown in Figure 12. The returning sound waves create a stress (pressure wave) on the transducer, which causes a voltage change to occur in the piezoelectric material.

There are two types of sound waves used for ultrasonic fuel inspection at poolside: longitudinal and shear waves. Longitudinal waves are compressional waves and have characteristic compressional and rarefraction particle displacement zones. The particle motion (atomic scale) is in the same direction as the wave front propagation. Unlike longitudinal waves, shear. waves do not have rarefaction or compressional zones. Shear waves have particle motion that is orthogonal (shearing action) to the wave propagation direction.

The velocity of a shear wave is approximately one-half that of the longitudinal wave. The wave length is an important parameter because the minimum detectable size of a defect is approximately the wave length of the sound used. The wave length of sound can be calculated for different inspection frequencies. Calculations for Zircaloy cladding are shown in Table 10. Note that detection of small cladding defects requires frequency selection in the

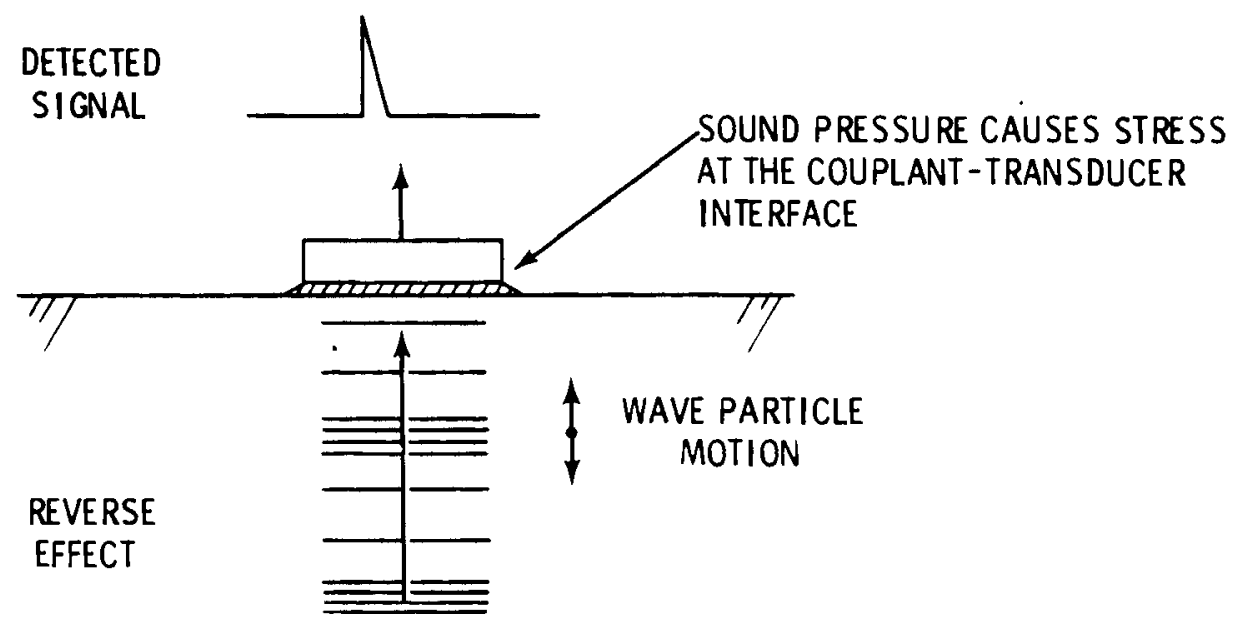

FIGURE 12. Reverse Piezoelectric Effect (Acoustic Sound Pressure Mechanical Thickness Change - Electric Signal Output) 
TABLE 10. Ultrasonic Properties of Zirconium and Zircaloy

Longitudinal Waves

$\begin{gathered}\text { velocity, } \\ 10^{3} \mathrm{~m} / \mathrm{s}\end{gathered}$
$\frac{15 \mathrm{MHz}}{15} \mathrm{MH} \mathrm{MHz}$

Material

Zirconium annealed

Zircaloy-2

cold-drawn tubing

Zircaloy-4

cold-drawn tubing
4.6

310

308

302

4.62

4.53
$3 \mathrm{MHz}$

155

154

151

2.34

156

78

Shear Waves

Velocity, wavelength, $\mu \mathrm{m}$

$\begin{array}{lll}2.25 & 150 & 75\end{array}$

2.44

162

81

megahertz region (ultrasonic region). For shear waves at $30 \mathrm{MHz}$ in Zircaloy-4 cladding, the minimum detectable defect size is $81 \mu \mathrm{m}$.

A most important property of ultrasound is its inability to completely traverse an unfavorable acoustic boundary, such as a crack or other anomaly embedded in the test material. A precentage of the total sound energy is reflected back to the sending transducer. Because of this unique property of ultrasound, defects in materials can be detected.

Whenever ultrasonic waves strike the interface of two different materials (such as the water-fuel cladding interface or the fuel pellet-cladding interface) a percentage of the sound energy is reflected. At some acoustic boundaries the incident sound energy $\left(E_{i}\right)$ is totally reflected.

Description of Ultrasonic Testing

Ultrasonic systems used for fuel rod testing are described below.

Ultrasonic System Components

Ultrasonic test systems used at poolside are composed of three major subsystems, including: a) piezoelectric transducer, b) ultrasonic instrument, and c) data recording and display instruments. A basic block diagram of the system is shown in Figure 13.

One fuel vendor stated that they had developed their own ultrasonic test instrument to meet their specific testing needs. Another fuel vendor uses a 


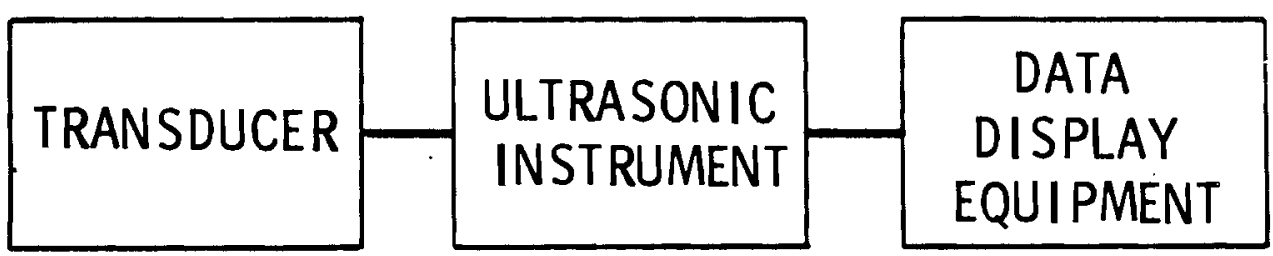

FIGURE 13. Block Diagram of Ultrasonic Test System

commercially available instrument and employs the oscilloscope cathode ray tube (CRT) display to interpret signal data.

Transducer. Focused ultrasonic transducers are used for poolside fuel inspection. The addition of an acoustic lens element to the front face of the transducer causes a focusing of the ultrasonic beam as shown in Figure 14. Focused transducers have several advantages, including: reduction in effects of surface roughness, reduction in effects of surface contour (geometry), reduction of metal noise (echo reflections from small discontinuities in the metal), increased resolving power, and increased sensitivity to small defects.

The transducer is a key component in the inspection system. Through the piezoelectric phenomenon, the transducer is the link between the specimen being tested and the system instrumentation used to perform the testing. The single element transducers used for poolside inspection vary in size (diameter) and design frequency of operation. Poolside inspection requires that the transducer(s) be placed in an adjustable head fixture that is submerged. The transducers are sealed in a metal case and are essentially unaffected by the high radioactivity levels experienced during poolside testing.

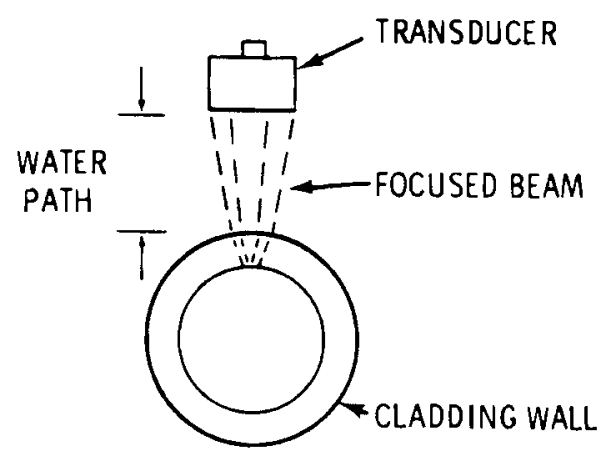

FIGURE 14. Focused UItrasonic Transducer 
The piezoelectric crystal fits securely into the machine metal case. One face of the crystal is grounded to the metal case while the other is connected to the "hot" lead. The "hot" lead is connected to the instrument pulser, which supplies a high-voltage excitation pulse to the piezoelectric crystal.

Signal Processing. The generation and electronic processing of ultrasonic signal information is done with the ultrasonic instrument. A functional diagram of a pulse-echo instrument is shown in Figure 15 (McMaster). All of the

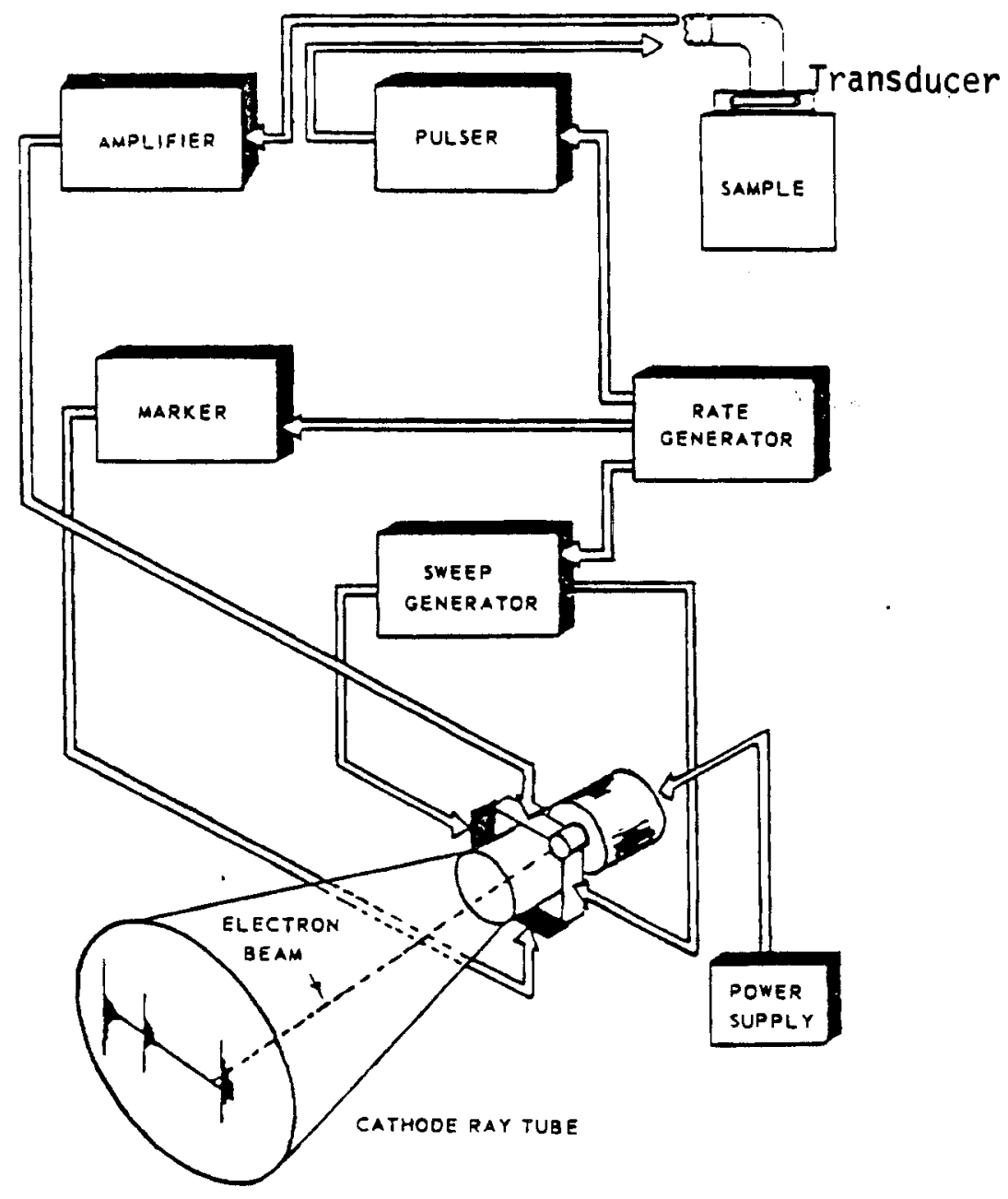

FIGURE 15. Functional Diagram of Pulse-Echo Ultrasonic Instrumentation (McMaster) 
ultrasonic instruments used at poolside have a basic time-amplitude scan ( $A$ scan) CRT presentation that indicates the defect depth and response amplitude.

The rate generator (synchronizer) shown in Figure 15 is used to simultaneously trigger the pulse and start the horizontal sweep of the CRT. The pulser sends a high-voltage pulse to the piezoelectric transducer, which, by the forward piezoelectric effect, generates ultrasonic waves into the specimen under test. Any returning pulses (echoes) are detected by the reverse piezoelectric effect. This returning signal is amplified and applied to the vertical defection plates of the CRT. The amplitude of the signal displayed on the CRT is proportional to the amount of returning energy incident on the transducer. The position of the received echo on the horizontal display of the CRT indicates the distance traveled by the ultrasound in the specimen.

A typical A-scale presentation is depicted in Figure 16. Shown in the figure are the reflection from the front surface, back surface, and the defect. The A-scan presentation shows that the defect is located in the bottom half of the test specimen, based on the position of the front and back surface reflections.

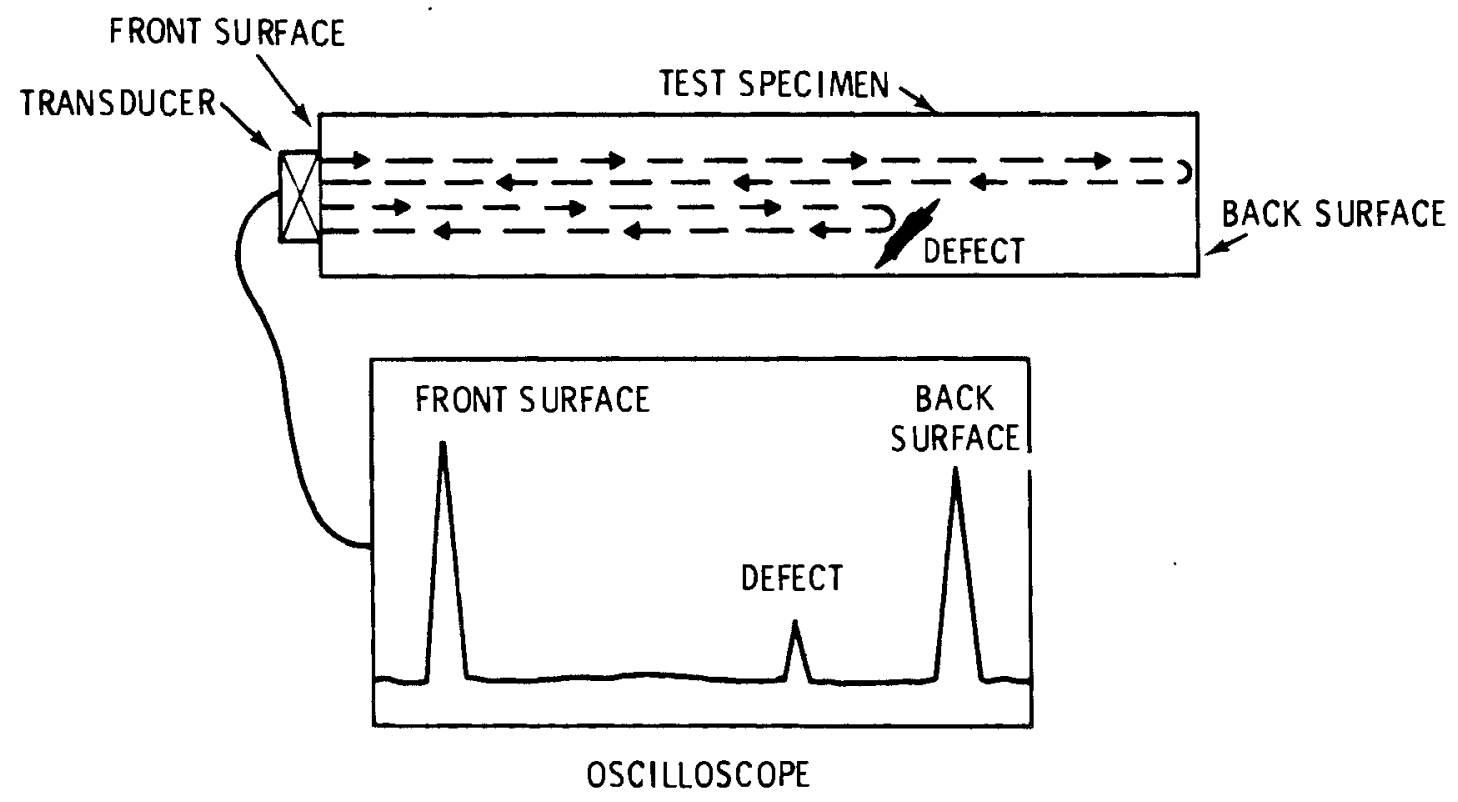

FIGURE 16. Typical Ultrasonic Time-Amplitude Scan (A-scan) Presentation 
Data Recording and Display. One fuel vendor uses the CRT display for analysis of ultrasonic information during the inspection; however, they do not record the ultrasonic data on a strip chart or a magnetic tape recorder. Another fuel vendor records poolside ultrasonic data using a strip chart and magnetic cassette recorder.

Ultrasonic Inspection at the Spent Fuel Storage Pool

Remote Inspection Operations. Because of the high radioactivity of irradiated fuel, ultrasonic inspection at poolside requires remote handing equipment, including a fixture (test station) that is positioned in the storage pool. The fixture holds individual fuel rods in a vertical position while the ultrasonic transducers traverse and inspect the fuel rod cladding. The ultrasonic system instrumentation is located adjacent to the spent fuel pool where the test personnel can visually observe the handling, positioning, and inspection operations. A crane is used to transport fuel bundles in the storage pool. Fuel bundles scheduled for ultrasonic inspection require disassembly. Individual fuel rods are carefully withdrawn from the bundle and placed in the inspection station. Underwater cameras are used to assist personnel in fuel handling and ultrasonic inspection operations.

Poolside U1trasonic Inspection. Ultrasonic testing is used to a) detect water entry into the fuel rod (indicates a breach in the fuel cladding), b) detect defects in the fuel cladding, and $c$ ) determine if fuel pellet-cladding bonding has occurred. A discussion of techniques a and b follows.

Ultrasonic Leaker Test. At domestic plants, only one fuel vendor uses ultrasonic inspection to determine the presence of water in fuel rods. For such inspections, the fuel rod is held vertically. The transducer traverses the length of the fuel rod by means of a motor that drives the head fixture.

The principle used to detect water entry into the fuel rod involves a change in the amplitude of reflection from the inner cladding surface. If water had entered the fuel rod through a breach in the cladding and is in contact with the cladding inner wall, the incident ultrasonic energy would be 
coupled and transmitted to the fuel pellet. The presence of water in the rod causes a change in the ultrasonic signal at this interface (acoustic signature). Figure 17, shows the oscilloscope presentations of the reflected amplitude from the outer cladding wall surface interface and the inner cladding wall surface interface that are characteristic of a "nonleaker" fuel rod and a "leaker" fuel rod. The threshold gate is an electronic means of providing an acceptance "window," whereby only signals occurring within the time gate (i.e., $t_{1}$ to $t_{2}$ in Figure 17) will be recorded.

A similar approach to rod testing is used by one foreign company at European reactors. Briefly, this technique involves heating and cooling of the bottom end of the fuel rod; it is theorized that water entering the rod would accumulate at the bottom of the rod. This company's fuel bundle is designed so the lower tie plate can be readily removed. Before removal of the lower tie plate, the fuel bundle is turned upside down. The tie plate is removed and a special device for detecting defective fuel rods is placed over each rod to be inspected as shown in Figure 18 (Knaab 1977). The device is designed so that the ultrasonic beam can be focused to a point on the inner wall of the lower end cap (plug). The principle of operation requires that

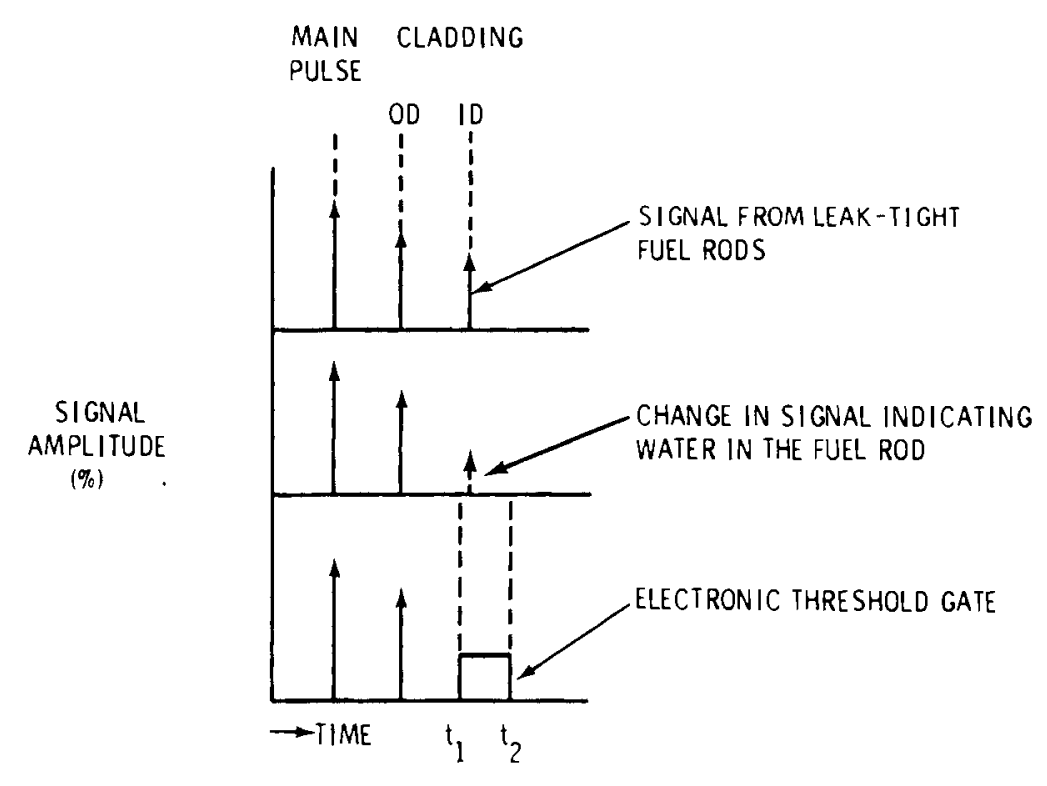

FIGURE 17. Time-Amplitude Scan (A-Scan) Display for Ultrasonic Leaker Test 


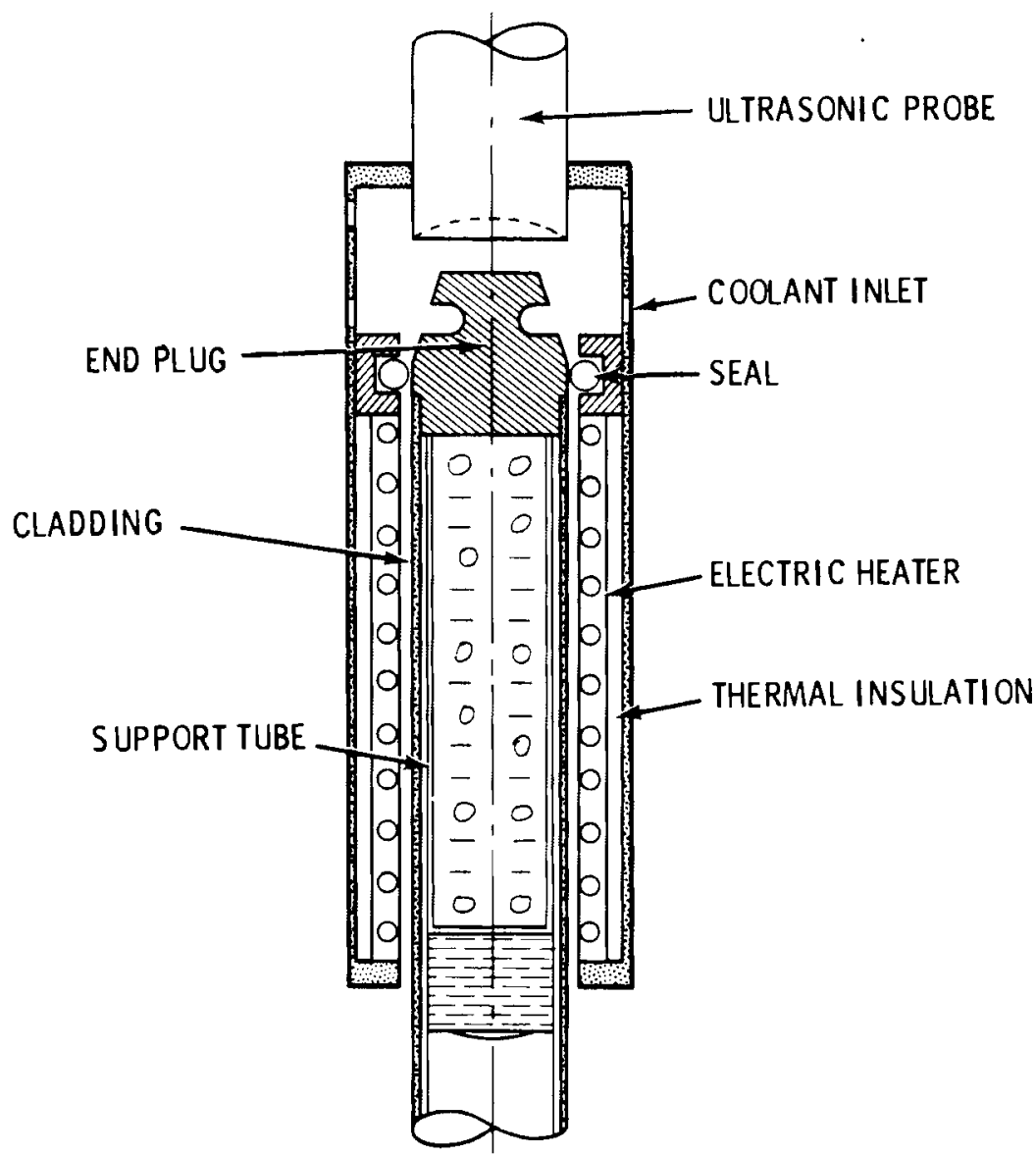

FIGURE 18. Special Device Used by a Foreign Company to Find Defective Fuel Rods by Detecting Water Inside the Rods (Knaab 1977)

the heating coils encircling the fuel rod convert any water within the rod to steam. The steam rises until it condenses on the bottom surface of the end cap. Cooling water circulates in the upper portion of the device causing the steam to condense on the inner surface of the end cap. A characteristic acoustic signature response indicates water within the fuel rod. This device has been used to inspect irradiated European LWR fuel for over three years, and was reported to be a successful measurement technique.

Ultrasonic Defect Test. One domestic fuel vendor has performed a 1 imited number of ultrasonic inspections where the ultrasonic transducer was positioned so that shear waves are transmitted circumferentially around the cladding wall. The test was intended to detect axially oriented defects in 
the cladding as shown in Figure 19. The fuel rod is rotated and translated past the inspection transducer. Defects in the cladding product signals that can be viewed on the instrument A-scan display (Figure 16). The severity (depth) of a given defect indication (signal amplitude) is determined by comparing the signal amplitude of the defect to the amplitude response from artificial, electric discharge-machined (EDM) slots in the standard.

Ultrasonic Test Standards. The test standard for the ultrasonic defect test is fabricated from Zircaloy fuel cladding with the same wall thickness

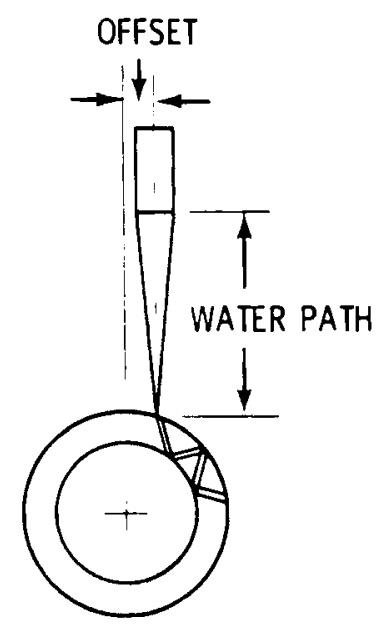

CRACK

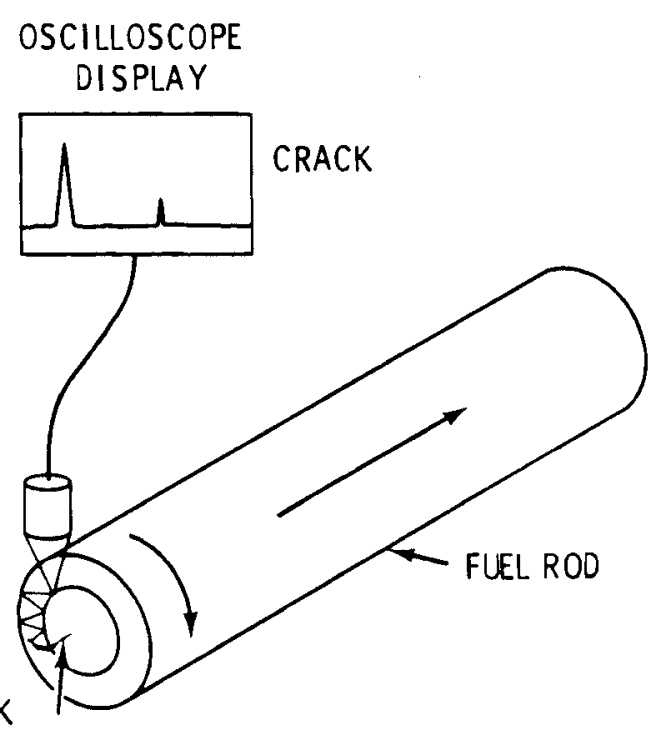

IN CLADDING

FlGURE 19. Ultrasonic Defect Test that Employs 450 Shear Waves 
and diameter as the fuel rods to be inspected. Axial EDM slots of varying depth and length are machined on the cladding inner and outer surfaces.

The test standards fabricated for the ultrasonic leaker test and pelletcladding bond test are different from the EDM slot standard used for the defect test. For the leaker test and pellet-cladding bond test standards, an attempt is made to simulate a condition at the cladding inner wall surface that would cause characteristic acoustic signals (signatures) that are indicative of coolant water entry. The ultrasonic leaker test standard would likely contain water within the standard.

Ultrasonic System Calibration. During ultrasonic inspection at poolside, the inspection system is periodically checked for calibration sensitivity. Typically, the system would require a calibration check a) at least once every $4 \mathrm{~h}$; b) whenever a component of the system (e.g., transducer) is replaced; c) whenever there is a personnel shift change; d) after a specific number of rods have been inspected; and e) whenever the operator suspects that the system is not in proper operation.

\section{Experience Survey}

Defect Test

One domestic fuel vendor indicated that they did not have extensive experience using this technique at poolside. They were generally uncertain about the interpretation of the defect test results because they did not presently have a test standard for use at poolside. This fuel vendor stated that with fuel rods exhibiting some degree of ultrasonically detectable anomalies, those indications occurred at the same axial locations as the indications of pellet-cladding bonding.

This fuel vendor further explained that they had not yet inspected a fuel rod where there was a defect indication of such significance that the rod would be suspected of being a potential leaker. Hence, no fuel rods have been rejected to date using this technique, and a criteria for rejection has not been firmly established. A test standard is now being fabricated and a 
criteria for acceptance/rejection will be established in the future. This fuel vendor could not comment on the sensitivity and reliability of detection at this time.

\section{$\underline{\text { Leaker Test }}$}

Another domestic fuel vendor uses ultrasonic testing to detect water in the fuel rod. If water is determined to be present in the fuel rod, the rod is rejected. This vendor also reviews and compares the eddy current data and visual inspection results before rejecting any fuel rods.

\section{Frequency of Ultrasonic Inspection}

Ultrasonic inspection is not routinely used at poolside fuel inspections. Only two of the five domestic fuel vendors use ultrasonic techniques at poolside.

One fuel vendor explained that if only two fuel bundles in the core were designated as leakers as a result of the sipping test, nondestructive examinations (ultrasonic, eddy current, etc.) would not likely be performed on those bundles, and the leaker fuel bundles would simply by replaced with new bundles. This fuel vendor indicated that they are interested in performing ultrasonic or eddy-current testing when they feel that the failure mechanism is perhaps different than that experienced in the past. For example, hydride failures were common with some fuel manufactured prior to 1975 . Today fuel rod failures resulting from pellet-cladding interaction are being studied.

One fuel vendor stated that when fuel rods fail and complete bundles are replaced, there is an obvious economic penalty accrued by the fuel vendor. However, this must all be weighed against the cost-benefit of a nondestructive inspection program. Ultrasonic testing is sometimes used by one fuel vendor to inspect selected rods from lead test fuel bundles.

One fuel vendor stated that they perform the ultrasonic defect test and pellet-cladding bond test on all of the fuel bundles they disassemble at poolside. That vendor explained that on a per year basis, fuel bundles are disassembled at approximately half of the plants at which they perform fuel inspections. 


\section{Time and Personnel Requirements}

One fuel vendor's experience indicates that it requires $\sim 1$ min per fuel rod to perform the leaker test after the equipment is set up. This inspection requires a two-person team, one to operate the inspection station while the second watches the instrument oscilloscope display. This vendor stated that often the rod will be re-examined, and the inspectors will try to pinpoint the defective area of the rod. Thus, a 1-min inspection rate is the minimum time required for the examination of a single fuel rod.

Another fuel vendor stated that it requires a few minutes to perform the defect test and pellet-cladding bond test per fuel rod. For these tests, this vendor uses a two-person team.

\section{Limitations to Ultrasonic Testing}

As was the case with eddy-current inspection, each of the poolside ultrasonic inspection techniques requires that the fuel bundle be disassembled so fuel rods can be individually tested.

One fuel vendor presently uses a focused transducer with a $0.38-m m-d i a$ beam at the focal point to perform the defect test. The fuel rod is rotated at 3000 rps (with 4200 rps the maximum permissable). At the current rotation rate of 3000 rps and with a beam overlap of $0.127 \mathrm{~mm}$, a total (100\%) volumetric inspection of the fuel rod cladding requires 100 revolutions to traverse $25.4 \mathrm{~mm}$. To traverse the entire active length of the fuel rod (typically $3658 \mathrm{~mm}$ ) would take $4.8 \mathrm{~h}$ per rod. Inspecting 100 rods would take $\sim 3$ wk working $24-h$ days. Thus, the $100 \%$ volumetric defect test is presently impractical.

The vendor indicated that when performing the ultrasonic defect test it is important that the alignment of the system is correct. Standards are needed to assure precision alignment and were not available when the initial tests were done. This vendor will require that system alignment be checked periodically after a certain number of rods have been inspected. Thus, additional time will be required to perform these checks. 
The fuel vendor also stated that they were concerned with the condition of the cladding outer and inner wall surfaces when performing the defect test. Outer wall surface roughness caused by scratching, fretting at the spacer grid contact areas on the fuel rods, oxide buildup, ridging, etc., would likely cause problems in interpretation of data. These surface anomalies disrupt the ultrasonic beam. Inner wall surface roughness such as scaling or fabrication process marks cause reflections that can complicate the interpretation of test results.

Another fuel vendor stated that in performing the ultrasonic leaker test it is the responsibility of the data analyst to interpret the A-scan data during fuel rod inspection. There is no analog strip chart recording of data.

Poolside Inspection Hazards

Ultrasonic inspection does not alter its subject. There are no apparent hazards in performing ultrasonic inspection. The greatest potential hazard to fuel integrity is not the inspection itself but the associated remote handling and transport operations with fuel bundles and rods.

Hot Cell Ultrasonic Inspection

Hot cell and poolside ultrasonic inspection results are compared to the metallographic results from hot cell destructive examinations. The metallographic results are used to confirm the nondestructive test data and provide the means for determining ultrasonic inspection sensitivity and reliability of detection.

In addition, destructive examination data are used to help establish the criteria for acceptance and rejection of fuel rods and to characterize degradation mechanism.

\section{Ultrasonic Inspection of Irradiated Fuel}

In the study described in Patel et a1. (1973) two series of ultrasonic inspections on irradiated fuel rods [burnup was $788 \mathrm{GJ} / \mathrm{kg}$ of heavy metal (U)] were conducted. The results from one series showed that ultrasonics detected several fuel chips, $\sim 20 \mu \mathrm{m}$ by $150 \mu \mathrm{m}$, bonded to the cladding inner wall with an adjacent cladding crack $\sim 20 \mu \mathrm{m}$ deep emanating from the bonded area. 
In the second series of tests, irradiated fuel rod cladding (the $\mathrm{UO}_{2}$ pellets had been removed) produced signals in four specimens that were approximately equal to or greater than the response from the standard EDM slot. The metallographic results from suspect sections confirmed the presence of defects in four of the five specimens. In addition, cladding sections having no apparent defect indications were metallographically examined, and in all cases the metallographic results confirmed that no defects or anomalies existed.

It was indicated in the report (Patel et al. 1973) that some of the cracks were less than $25 \mu \mathrm{m}$ deep, while others had penetrated to a depth of $60 \mu \mathrm{m}$ (wall thickness $380 \mu \mathrm{m}$ ).

The results indicated that a routine ultrasonic pulse-echo technique was successfully used to detect defects in irradiated fuel rods when the defects were $<10 \%$ of the wall thickness.

This study showed the potential to ultrasonically discriminate between outer surface circumferential ridge defects, incipient cracks, hydride/deuteride defects, and fuel chips. The metallographic results from this study showed that the ultrasonic inspection technique, using $15 \mathrm{MHz} 45^{\circ}$ shear waves, was a highly reliable and sensitive method of inspection.

\section{Future Ultrasonic Capability}

Two of the fuel vendors indicated that they did not anticipate further development or use of ultrasonic inspection techniques beyond the current capabilities at poolside. The hot-cell ultrasonic test results reported in Patel et al. (1973) were encouraging and indicate that ultrasonic testing has demonstrated a capability to play an important role in postirradiation testing and possibly at poolside. It would appear that the ultrasonic leaker test system used by one of those two vendors has thus far proven to be adequate for detecting failed fuel rods. Because of the limited experience at poolside using both the ultrasonic defect test and pellet-cladding bond test, little can be stated about the potential for these techniques. However, as for the future poolside capability of the defect test used by the other fuel vendor, Patel et al. (1973) concluded: 
Ultrasonic testing has a high potential for further development. A "museum" of typical defect signals (including a frequency analysis) documented with metallographic features could allow for a reliable interpretation of signals without a destructive examination. This may lead to a complete nondestructive test of irradiated fuel rods which are periodically inspected through several successive irradiations to observe how defects develop. Such a technique will be a powerful tool for assessing potential failure mechanisms.

Recently there have been several published studies (Meck et al. 1977; Adaptronics Inc. 1975) that show results obtained using computer analysis techniques for the interpretation and evaluation of ultrasonic signal information. This advanced analys is approach could possibly improve upon current poolside inspection capability.

One limitation of the ultrasonic defect test is that it would require $4.8 \mathrm{~h}$ to perform a $100 \%$ volumetric test using a single transducer. A multiple transducer system could be built to alleviate this problem. An improved system for positioning (alignment is critical), holding, and rotating the fuel rod could be built so the rod could be tested in either the vertical or horizontal position. Rod rotation rates could likely be much greater than the current maximum of 4200 rps, thereby decreasing the testing time.

Comments on Failed Fuel

The ultrasonic leaker test is used by only one of the domestic fuel vendors, and in this case it is used as a supplement to eddy-current testing. This vendor indicated that the technique has proved to be adequate for detecting leaker rods. 
CONCEPTUAL DESCRIPTION OF WET SIPPING

SYSTEM FOR 225-B BUILDING POOL CELLS

This section provides a conceptual description of a wet sipping system that may be used for leaking capsule identification in the 225-B Building water storage pools.

ISOLATION

The isolation wet sipping approach consists of placing a container (open at the bottom) over a capsule or rack of capsules in-situ and sampling the container water for radionuclide concentration increase. This system is shown in Figure 20, and the principal elements are defined in Table 11.

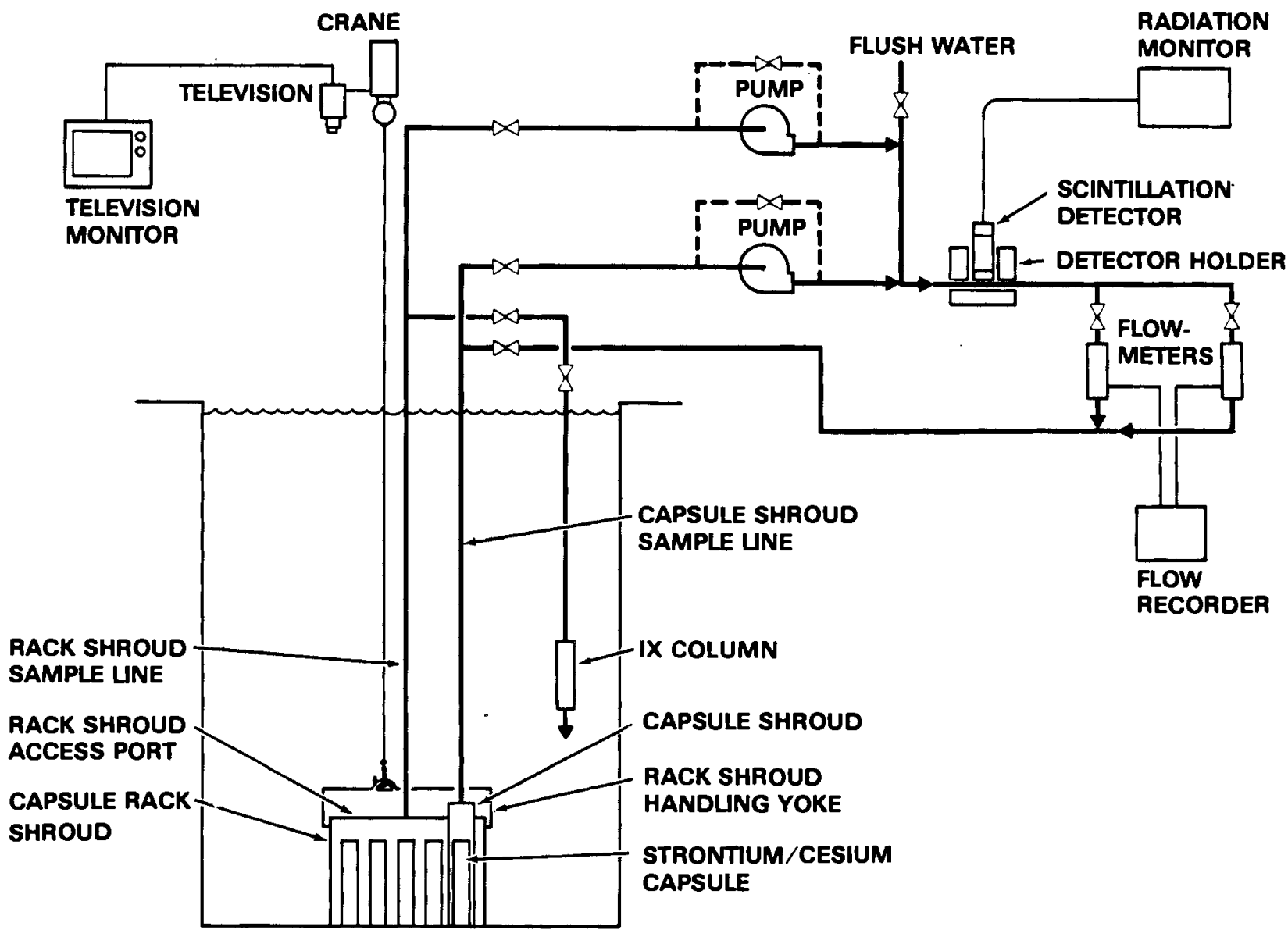

FIGURE 20. Wet Sipping System 
TABLE 11. Wet Sipping Equipment Requirements

Rack Shroud - Custom

Capsule Shroud - Custom

Shroud Handling and Sampling Appurtenances - Custom

Detector Holder - Custom

Sample Line Valves - Custom

Pump (Peristaltic, Gear, Submerged Centrifugal)

Scintillation Detector (Typical - Canberra)

Detector ( $\mathrm{Nal}(\mathrm{Ti})$ ), photomultiplier, housing: 802-3

Base, preamplifier: $2007 \mathrm{P}$

Radiation Monitor (Typical - Canberra)

High Voltage Supply: 3102

Amplifier: 2012

Single Channel Analyzer: 2023

Liner Ratemeter: 2081

Single Channel Analyzer Sweep: 833

Strip Chart Recorder

Rack or Combined Instrumentation as the Series 30 MCA.

Flowmeter (Magnetic)

Flow Recorder

IX Column

For this system, the following approach is used to locate the leaking capsule included in a storage pool that contains multiple racks filled with capsules of either cesium or strontium. Initially, a determination is made whether either radionuclide is leaking by performing a gamma energy analysis of the contaminated pool water to determine if the Ba-137 photopeak is present. If present, then a cesium capsule is leaking; if not, strontium is leaking. This determination narrows down the numbers of racks that may contain the leaking capsule. Then, the rack containing the leaker is determined by wet sipping or by the concentration gradient method described in "Wetting Sipping," beginning on page 26 . 
A shroud is placed over a rack containing the suspected "leaker." Pool water is drawn continuously through the shroud water sampler past a gamma scintillation detector before its return through the shroud. The water is continuously monitored for radionuclide concentration buildup. If there is significant buildup, the rack with the leaker is located. If the rack examined does not indicate that the leaker is present, another rack is tested. Once the rack with the leaker is located, a shroud is placed over individual capsules and the enclosed water is continuously circulated past the detector and back to the shroud until the leaking capsule is identified. This last step may be time consuming since each capsule must be examined until the leaker is found.

It is important for the successful implementation of this concept that the water in the shroud be allowed to "stagnate" to allow radionuclide buildup in the water contained in the shroud. Also, in moving the shroud between detection measurements, it must be recognized that there is the possibility of the shroud becoming contaminated at one measurement point, and that this contamination may carry over to the next measurement point and cause some error in the water contamination level.

A key question about the accuracy of this technique is the potential for leakage of radionuclide contamination into or from the bottom open-ended shroud. It is not felt that leakage into the shroud from the bottom is a significant problem since the net flow of pool water is in the vertical rise direction, and the water entering the bottom of the pool is "clean" or at a substantially lower contamination level. The net flow of pool water into the sample shroud is negligible since the sample water is returned to the shroud. If it is felt that pool contamination is a problem, demineralized water may be supplied to the open end of the shroud to prevent pool water from entering the shroud. Leakage of water from the shroud to the pool is no problem unless it is desired to contain all radionuclide contamination within the shroud to limit or eliminate pool contamination. Then, an adequate net flow of water needs to be maintained through the shroud to prevent migration of the radionuclides out the open end of the shroud. The continuous sample water removed from the rack 
shroud may be decontaminated before its return to the pool if it is desired to prevent pool contamination during individual capsule testing. It is not anticipated that water boiling in the shroud, whether over a capsule or basket, will occur as the result of inhibited heat transfer.

The basic elements of the isolation wet sipping system include the following:

- Shroud: Rack and Capsule

- Sample System

- Radiation Monitoring

- Equipment Handling

- Sample Water Decontamination.

Rack and Capsule Shrouds

The rack shroud consists of a 304L SS rectangular parallelpiped she 11 which is open at the bottom (see Figure 21). The shroud is handled with the crane hook which connects to a bale on the shroud. Connected to the shroud is the vent to release trapped air (the sample line can be used) and the water sample and return lines. The top of the shroud can also have individual lids on it to enable passage of the capsule shroud for individual capsule sipping. The caps may be handled by the crane hook, by an attachment to the crane hook, or manually by a hook. These caps would isolate the basket capsules from the pool while individual capsules were tested.

The capsule shroud consists of a section of 304L SS pipe that is closed at one end (see Figure 22). It also has a bail and sample and return lines attached for handling and sampling that are similar to the basket shroud. Sampling System

The sampling system consists of lines, connections, valves, pumps, and flow-metering systems used for sample pool-water handling. These are shown on Figure 20.

Component selection, design, and configuration are sensitive to the operating and maintenance philosophy of the system. Specifically, a fully remote operating/maintenance system would be different from hands-on 


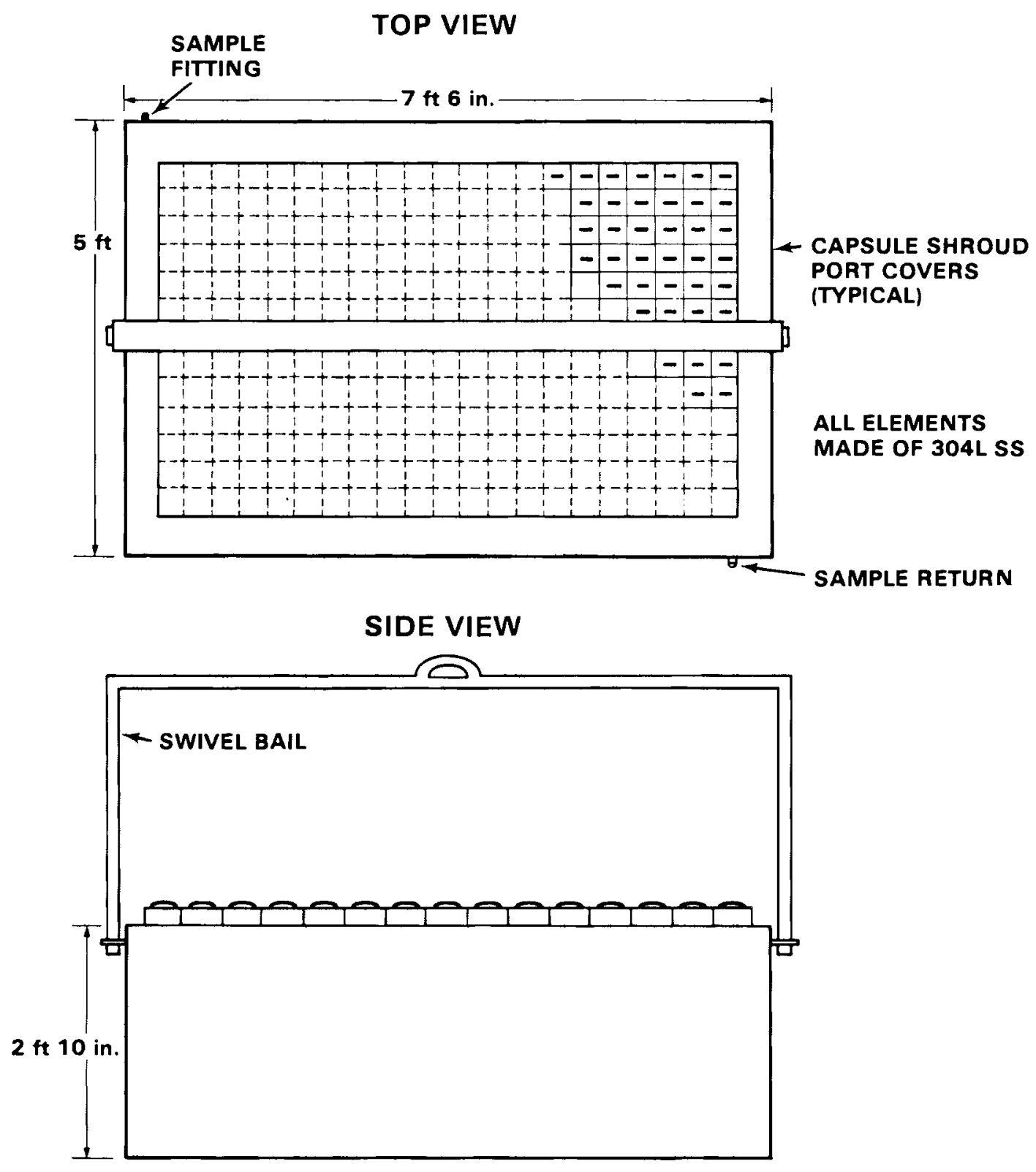

FIGURE 21. Rack Shroud

operation/maintenance within the storage area. Also, handling of equipment that has been in the contaminated pool is a design factor. Sample lines may be constructed of plastics such as polyethylene where flexibility is required and $304 \mathrm{~L}$ tubing or pipe where the lines are fixed. Swagelock fitting may be used for connections. If fully remote operation/maintenance is used, Hanford or PNL connectors may be used (although this is complicated and expensive). 
PLAN VIEW

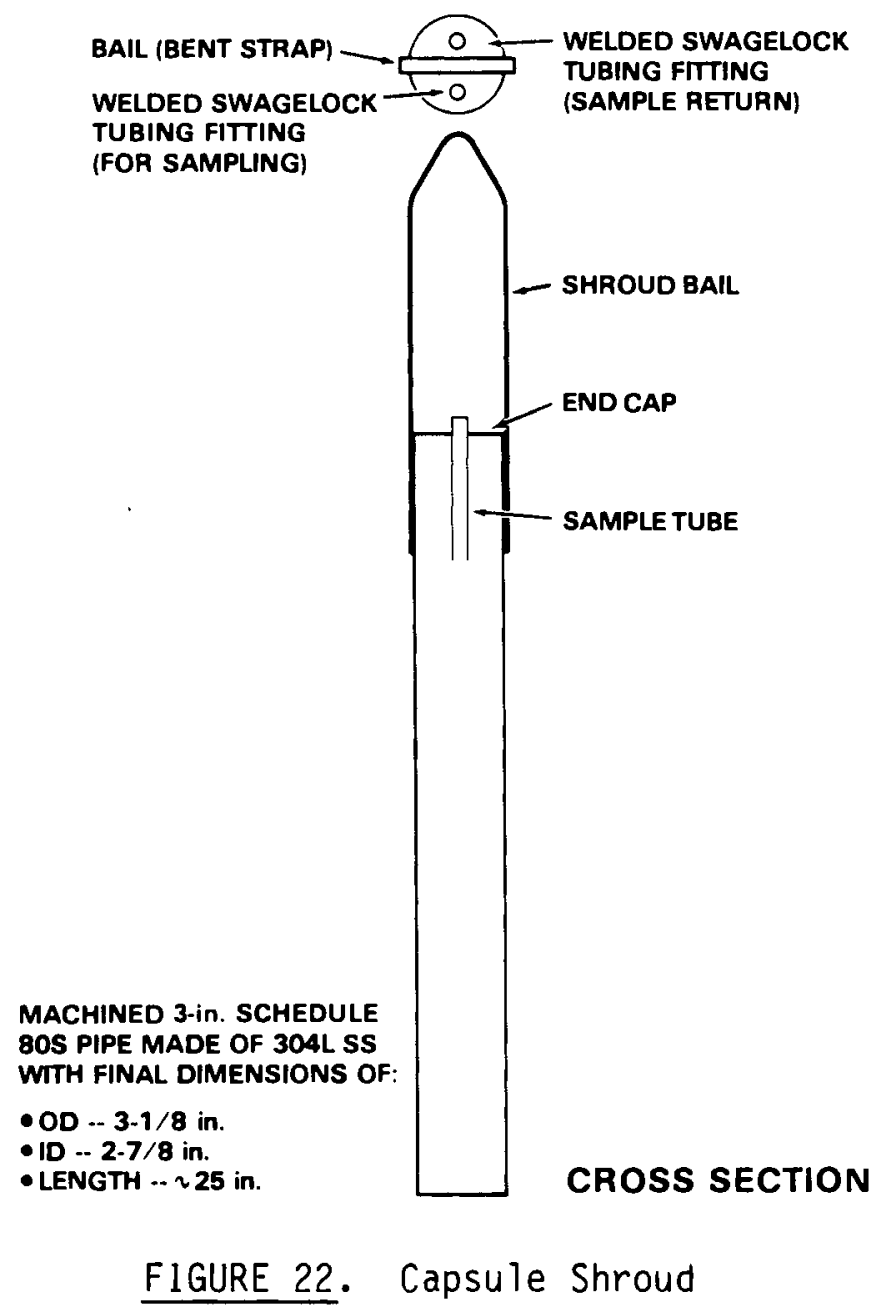

Valves and pumps should be selected according to use, operating methods, and maintenance. For instance, if the pump is located out of the pool, above the water level, and for flow control, a sealed gear pump should be considered for use. Also, associated flowmeters with remote recording should be considered for use to confirm proper sampling system operation.

\section{Radiation Monitoring}

The radiation monitoring system consists of the detector, associated electronics and a readout system. Typical monitoring system components are indicated in Table 11. Although there is much flexibility in choosing system components, it is recommended that a $\mathrm{Nal}(\mathrm{Ti})$ detector be used and that the 
capability exist to detect a Ba-137 photopeak and a general gamma activitylevel range. There should also be continuous monitor signal recording as well as indication. As part of the monitoring system, a detector holder is needed to maintain the detector in a fixed geometry in relation to the radiation source (sample line) being monitored. The sample line in the holder should be designed such that air will not be trapped in it. Finally, the ability should exist to flush the sample lines for decontamination if desired.

\section{Equipment Handling}

The shrouds in the pool and associated appurtenances will require handling during use. This can be normally performed with the crane hook with appropriate design. However, consideration should be given to monitoring these operations with a crane-mounted, remotely monitored television camera to minimize operator exposure in the storage area during operations. Also, consideration has to be given to handling of contaminated lines, cables, and equipment that have been placed in the contaminated pool.

Sample Water Decontamination

It may also be desirable to route the sample or shroud water through an ion exchange system to avoid its recontamination of the pool. This can be accomplished by providing a small cation-exchange column located in the pool with the leaking element.

\section{CONCENTRATION GRADIENT}

The concentration gradient method consists of continuous point sampling of contaminated pool water at different locations in the pool in relation to potential contamination sources in order to follow the increasing radionuclide concentration as the contamination source is approached. This system is similar to and can be the same system as described for individual capsule wet sipping as previously described. Thus, if the "bell jar" approach is used for wet sipping of individual capsules, this method can be used.

In this approach, the sampler (capsule) shroud is placed in the pool water. The sampler is methodically moved to various locations in the pool in 
relation to potential contamination source locations. Continuous radiation monitoring of the pool water would indicate a radionuclide concentration gradient in the water. This gradient could, in theory, be followed with the sampler to the leaking source. Then, the course could be confirmed by the isolation wet sipping method. This approach is very simple and could substantially reduce the time and operations needed to detect a leaking capsule by other methods. However, it is expected that because of the potentially complex flow patterns of water in the pool and the difficulty of defining the patterns, together with the probable slow contaminant leak rate, it would be difficult to practically implement and rely on this technique.

\section{CONCEPT IMPLEMENTATION AND DEVELOPMENT}

The concept of wet sipping is a well-established industrial technology for detecting leaking spent nuclear fuel elements. However, the adaption of this technology for capsule leak detection requires some individual assessment and possibly demonstration. Areas requiring further consideration for implementation include the following:

- Component fit Tolerances: The dimensions of the capsules, capsule shroud, basket opening, and basket shroud opening require fairly close fitting components (component gaps are a fraction of an inch). These tight $f$ it tolerances appear marginal for remote or semi-remote component placement in the pool. A review by operating personnel and testing are warranted before committing to the concept.

- Open Bottom Shrouds: The open-bottom shrouds allow for some mixing or contact between shroud and pool water. This water exposure could cause some measurement uncertainties resulting from absence of complete container water isolation. It is not felt that the open-bottom shroud will significantly introduce measurement errors unless there is significant interchange of water between the pool and the shroud. This would require that the shroud sample water be returned to the shroud. 
- Basket Shroud Heatup: Preliminary calculations indicate that if a basket is filled with strontium-90 capsules generating the maximum amount of heat, then the water could heat up to boiling. Thus, under these circumstances, steps are necessary to provide supplementary heat removal from the basket, such as by providing a moderate circulation rate through the sampling system along with the associated heat dissipation to the pool water through the transfer lines.

If these areas cannot be satisfactorily resolved for the in-situ wet sipping of capsules, which would necessitate the movement of the capsules for sipping testing, then fully enclosed wet sipping and ultrasonic testing for water in the capsule ought to be considered for application. 



\section{REFERENCES}

Adaptronics, Inc. 1975. Adaptive Nonlinear Signal Processing for Characterization of Ultrasonic NDE Waveforms. AFML-TR-75-24, Air Force Materials Laboratory.

Asamoto, R. R. et al. 1972. Evaluation of Irradiated Fuel Rods with Pulsed Eddy Currents. GEAP-13928, General Electric.

At lantic Richfield Hanford Company (ARHCO). 1973. Technical Manual - Waste Encapsulation and Storage Facility. ARH-MA-103, AtTantic Richfield Hanford Company, Richland, Washington.

Autio, H. A., (Yankee Atomic Electric Company) Letter to U.S.N.R.C. (Office of 1 and E, Region 1), Subject - Reportable Occurrence 50-29/78-31/01T-0, Degradation of Fuel Cladding, November 25, 1978, Docket Number 50029. (Sipping at Yankee Rowe revealed degradation of fuel cladding in four Exxon fuel bundles.)

Bailey, W. J. et al. 1980a. Assessment of Current Onsite Inspection Techniques for Light-Water React or Fuel Systems, Executive Summary. NUREG/CR-1380, PNL-3325, Vol. 1, Pacific Northwest Laboratory, Richland, Washington.

Bailey, W. J. et al. 1980b. Assessment of Current Onsite Inspection Techniques for Light-water Reactor Fuel Systems, Volume 2: Discussion of Inspection Techniques. NUREG/CR-1380, PNL-3325, VoT. 2, Pacific Northwest Laboratory, Richland, Washington.

Braden, D. E. et al. 1971. Safety Analys is Report - Waste Encapsulation and Storage Facilities. (Project HAP-631) ARH-1986, At Tantic Richfield Hanford Company, Richland, Washington.

Combustion Engineering, Inc. 1975. Joint CE/EPRI Fuel Performance Evaluation Program, Task C, Evaluation of Fuel Rod Performance in Main Yankee Core 1 . CENPD-221, pp. 1 and 5.

Combustion Engineering, Inc. 1976. Evaluation of Fuel Performance in Main Yankee Core 1, Task C. EPRI NP-218, p. 3-1, Electric Power Research Institute, Palo Alto, California.

Consumers Power Company. 1966a. Report of Operation of Big Rock Point Nuclear Plant, License No. DPR-6, November 1, 1965 Through Apri1 30, 1966. Docket No. 50155-13, Consumers Power Company.

Consumers Power Company. 1966b. Report of Operation of Big Rock Point Nuclear Plant, License DRP-6, May 1, 1966 Through October 31, 1966. Docket No. 50155-14, Consumers Power Company. 
Davis, T. J. 1977. "Selected Techniques for Obtaining Increased Sensitivity and Signal-to-Noise Ratios in Eddy Current Testing." Material Evaluation. 35(6):39-44, 1977. (Also page 13 in BN-SA-310, Pacific Northwest Laboratory, September 1974).

Duval1, F. C. and C. A. Negin. 1967. Dry Sipping Operations and Results at the Elk River Reactor During May 1967. NUS-394, NUS Corporation, Washington, $\overline{D C}$.

Eickelpasch, N., R. Seepolt and U. Wolff. 1974. "The Correlation of Power Changes, Activity Release and Fuel Performance at the KRB Power Reactor." In Enlarged Halden Programme Group Meeting, Sandefjord, Norway, June 1974.

Eickelpasch, N., R. Seepolt and U. Wolff. 1975. "Implication of Fuel Performance on the Plant Operation." Nuclear Energy Maturity, a paper in Volume 2, "Operating Experiences with Nuclear Power Plants," of the Proceedings of the European Nuclear Conference, Paris, April 1975, Pergamon Press, pp. 75-91.

Flora, J. H., V. Pasupathi, and J. S. Perrin. 1977. "Nondestructive Examination of Irradiated Fuel Rods Using Encircling and Probe Eddy Current Systems." 25th Remote Systems Tech. Symposium, San Francisco, California.

French, J. L. (Main Yankee Atomic Power Company), Letter to United States Nuclear Regulatory Commission, Subject - Special Report (Fuel Performance Report, Main Yankee Core 1A), dated September 23, 1975 (Docket No. 50309-378).

Gelhaus, F. E. 1977. The Cladding Flaw Growth Index: A Method for Corewide Fuel Rod Reliability Prediction. EPRI NP-324-SR, pp. 15 and 17, Electric Power Research Institute, Palo Alto, California..

Green, T:A. 1978a. "Detection of Defective Fuel Using Vacuum Sipping Technique." Trans. Am. Nuc1. Soc. 30:333-335, November.

Green, T. A. 1978b. "Monitoring Fuel for Defects." Power. 122(8):56-58, August. (Paraphrased with permission from POWER, August $197 \overline{8}$. Copyright, McGraw-Hi11, Inc., 1978).

International Atomic Energy Agency (IAEA). 1974a. Experience from Operating and Fueling Nuclear Power Plants. Proceedings of a Symposium held in Vienna, Austria, October 8-12, 1973, R. Billingham, "Fifteen Years in Nuclear Power," Paper No. IAEA-SM-178/100, pp. 183, 185, and 186.

International Atomic Energy Agency (IAEA). 1974b. Experience from Operating and Fueling Nuclear Power Plants. Proceedings of a Symposium held in Vienna, Austria, October 8-12, 1973, N. Eickelpasch, "Six Year's Experience with Core Performance at KRB Power Station Gundremmingen," Paper IAEA-SM-178/6, pp. 449-460. 
International Atomic Energy Agency (IAEA). 1974C. Experience from Operating and Fueling Nuclear Power Plants. Proceedings of a Symposium held in Vienna, Austria, October 8-12, 1973, 0. G. Gimstedt and S. 0. Hilding, "Experience from Operation of Oskarshamn Unit No. 1," Paper No. IAEA-SM-178/14, p. 224.

International Atomic Energy Agency (IAEA). 1974d. Experience from Operating and Fueling Nuclear Power Plants. Proceedings of a Symposium held in Vienna, Austria, October 8-12, 1973, Y. Kuge, R. Yamazaki, and W. Shinoda, "Experience with Fuel and Core Performances at Tsuruga Nuclear Power Station," Paper No. IAEA-SM-178/29, pp. 472 and 476.

International Atomic Energy Agency (IAEA). 1974e. Experience from Operating and Fueling Nuclear Power Plants. Proceedings of a Symposium held in Vienna, Austria, October 8-12, 1973, T. Tirupataiah, K. S. N. Murthy, and R. Rajaram, "Core Performance and Fuel-Handling Operating at Tarapur," Paper No. IAEA-SM$178 / 43$, pp. 533-536 and 539.

International Atomic Energy Agency (IAEA). 1978. Onsite Nondestructive Examination Techniques for Irradiated Water Reactor Fue T: Draft 2 ("Sipping," pp. 55-68).

Klein, L. T. 1966. Elk River Reactor Failed Fuel Element Detection. NUS-TMS-33, NUS Corporation, Washington, DC.

Knaab, H. 1977. "German Experience on Nondestructive Techniques for Reactor Fuel Characterization and Repair." Paper presented at the IAEA Consultant's Meeting in Vienna, November 23-25, 1977.

Lang, P. M. and S. L. Lindbeck. 1967. Operating Procedures and Review of Thermal Aspects of the Dry Sipping Method for Failed Fuel Detection, Elk River Reactor. NUS-TM-ES-5.

Madgett, J. P. (Dairyland Power Cooperative), Letter to R. Boyd (USNRC), Subject - Dairyland Power Cooperative LaCrosse Boiling Water Reactor (LACBWR), Provisional Operating License No. DRP-45, LACBWR Refueling Plan, Docket No. 50409-276, September 23, 1975. (Includes LAC-TR-026, "LACBWR Cycle 3 Fuel Performance and Refueling Plant for Cycle 4.")

Madgett, J. P. (Dairyland Power Cooperative), Letter to James G. Keppler (NRC), Subject - Dairyland Power Cooperative, LaCrosse Boiling Water Reactor (LACBWR), Provisional Operating License No. DPR-45, Reportable Occurrence No. 77-04, dated June 2, 1977 (Docket No. 50409-515).

McClintock, D. R. and T. A. Vizzini. 1972. "Development of On-Site Reactor Fuel Examination Capability." In Proceedings of 20th Conference on Remote Systems Technology, American Nuclear Society.

McMaster, R. C. Nondestructive Testing Handbook. Amer. Soc. for NDT, pp. 43-6 and 43-30, Columbus, Ohio. 
Meck, S. J. et al. 1977. Development of Ultrasonic Examination Methods for Austenitic Stainless SteeT Weld Inspection. HEDL-SA-1348, Hanford Engineering Development Laboratory, Richland, Washington.

Ogawa, S. Y., M. F. Lyons and R. E. Soulis. 1973. "Techniques and Equipment for Fuel Examinations at Power Reactor Sites." In Proceedings of 21st Conference on Remote Systems Technology, CRSTBJ 211-120 (1973), American NucTear Society.

Osborne, R. N. 1977. Device for Locating Defective Fuel. U.S. Patent 4,034,599, U.S. Patent Office, Washington, DC, July 12, 1977.

Pasupathi, V. et al. 1978. Determination and Microscopic Study of Incipient Defects in Irradiated Power Reactor Fuel Rods. EPRI NP-812, Electric Power Research Institute, Palo Alto, California.

Patel, H. B., A. Ditschson and A. E. Hunton. 1973. UTtrasonic Test ing of Irradiated Fuel Sheathing. AECL-4655, Chalk River Nuclear Laboratories, Atomic Energy of Canada Limited.

Peterson, R. H. (Pacific Gas and Electric Company), Letter to USAEC. Subject - Report on Fuel Assembly Cladding Defect Determinations Using the "Dry Sipping" Technique and Report on Increased Core Flow Resistance Due to Corrosion Product Scaling of Fuel, Docket No. 50133-4, February 24, 1966 (Humboldt Bay-3).

Programmed and Remote (PaR) Systems Corporation. 1978. Fuel Element Sipping System FES-1. Bulletin 100175. (Brochure describing the PaR Sipping System for dry and wet sipping of irradiated fuel after removal from the core. The system is designed and manufactured by PaR Systems Corp.)

Rosenbaum, H. S. (compiler). 1977. Data Package for BWR Fuel Rods Selected for Study in the Program "Determination and Microscopic Study of Incipient Defects in Irradiated Power Reactor Fuel Rods." NEDC-23557, Vol. 1, General Electric Company. This report is not publicty available because it has not been reviewed to determine whether it contains patentable subject matter, nor has the accuracy of its information or conclusions been evaluated.

Schroeder, H. J. 1969. "Searching for Failed Fuel Elements at the Gundremmingen Nuclear Power Plant." Kerntechnik. 3:139.

Sewe 11, R. B. (Consumers Power Company), Letter to USNRC, Subject - Request for a Change to the Technical Specifications of License DPR-6, Docket No. 50155-463, December 18, 1975 (Big Rock Point).

Sundstrand Energy Systems. 1977. General Out-of-Core Sipping Equipment Description and Sipping Advertisement Sheet, April 1977. 
Wachter, W. J. and R. B. Lee. 1976. "The Development of the Super-Sipper In-Core and Out-of-Core Failed Fuel Detection System." Winter Annual Meeting of the American Society of Mechanical Engineers, New York, New York, ASME Technical Division Publication 76-WA/NE-20.

Yancey, M. E. 1979. "Pulsed Eddy Current Inspection System for Nondestructive Examination of Irradiated Fuel Rods." In National Fall Conference, Am. Soc. for NDT, Paper Summaries, pp. 100-106, October 1979 (Work supported by the U.S. Nuclear Regulatory Commission Division of Reactor Safety Research under DOE Contract No. DE-AC07-761D01570).

Zach, J. and P. Kurtz. 1977. "Irradiated Fuel Sipping, Inspection, and Repair at Point Beach Nuclear Plant." In Proceedings of 25 th Conference on Remote Systems Technology, American Nuclear Society, pp. 377-385. 
No. of

Copies

OFFSITE

A. A. Churm

DOE Chicago Patent Group

9800 South Cass Avenue

Argonne, IL 60439

2 R. Y. Lowrey

DOE Albuquerque Operations Office

P.0. Box 5400

Albuquerque, NM 87185

A. L. Taboas

DOE Albuquerque Operations Office

P.0. Box 5400

Albuquerque, NM 87185

S. A. Mann

DOE Chicago Operations and Region Office

Argonne, IL 60439

J. 0. Neff

Department of Energy

Columbus Program Office

505 King Avenue

Columbus, $\mathrm{OH} 43201$

W. E. Mott

DOE Division of Environmental

Control Technology

Washington, DC 20545

J. P. Hamr ic

DOE Idaho Operations Office

550 2nd St.

Idaho Falls, ID 83401
No. of

Copies

J. W. Pee 1

DOE Idaho Operations Office

550 2nd St.

Idaho Falls, ID 83401

J. B. Whitsett

DOE Idaho Operations Office

550 2nd St.

Idaho Falls, ID 83401

C. R. Cooley

DOE Nuclear Waste Management

Programs

NE-331, GTN

Washington, DC 20545

G. H. Daly

DOE Nuclear Waste Management

Programs

NE-322, GTN

Washington, DC 20545

J. E. Dieckhoner

DOE Nuclear Waste Management Programs

NE-321, GTN

Washington, DC 20545

C. H. George

DOE Nuc lear Waste Management Programs

NE-330, GTN

Washington, DC 20545

C. A. Heath

DOE Nuclear Waste Management

Programs

NE-330, GTN

Washington, DC 20545 
No. of

Copies

M. L. Lawrence

DOE Nuclear Waste Management Programs

$N E-340, G T N$

Washington, DC 20545

D. J. McGoff

DOE Nuclear Waste Management Programs

NE-320, GTN

Washington, DC 20545

S. Meyers/R. Romatowski

DOE Nuclear Waste Management Programs

NE-30, GTN

Washington, DC 20545

G. Oertel

DOE Nuclear Waste Management Programs

NE-320, GTN

Washington, DC 20545

A. F. Perge

DOE Nuclear Waste Management Programs

$\mathrm{NE}-30, \mathrm{GTN}$

Washington, DC 20545

R. W. Ramsey, Jr.

DOE Nuclear Waste Management Programs

NE-301, GTN

Washington, DC 20545

V. Trice

DOE Nuclear Waste Management Program

$N E-30$, GTN

Washington, DC 20545

D. L. Vieth

DOE Nuc lear Waste Management Programs

NE-332, GTN

Washington, DC 20545
No. of

Copies

S. W. Ahrends

DOE Oak Ridge Operations Office

P.0. Box E

Oak Ridge, TN 37830

D. E. Large

DOE Oak Ridge Operations Office P.0. Box E

Oak Ridge, TN 37830

S. G. Harbinson

DOE San Francisco Operations Office

1333 Broadway

0ak land, CA 94612

W. B. Wilson

DOE Savannah River Operations Office

P.0. Box A

Aiken, SC 29801

R. P. Whitfield

DOE Savannah River Operations Office

P.0. Box A

Aiken, SC 29801

J. B. Mart in

Division of Waste Manajement

Nuclear Regulatory Commission

Washington, DC 20555

D. B. Rohrer

Division of Waste Management

Nuclear Regulatory Commission

Washington, DC 20555

R. D. Smith

Division of Waste Management

Nuc lear Regulatory Commission

Washington, DC 20555

R. E. Cunn ingham

Office of Nuclear Safety Materials and Safeguards Nuclear Regulatory Commission Room 562, 7915 Eastern Avenue Silver Springs, MD 20910 
No. of

Copies

27 DOE Technical Information Center

J. A. Buck ham

Allied-General Nuclear Services

P.0. Box 847

Barnwe 11, SC 29812

A. Williams

Allied-General Nuclear Services P.0. Box 847

Barnwe 11, SC 29812

J. H. Kittel

Argonne National Laboratory

Office of Waste Management

Programs

9700 South Cass Avenue

Argonne, IL 60439

M. J. Steindler/L. E. Trevorrow Argonne National Laboratory

9700 South Cass Avenue

Argonne, IL 60439

W. Carbiener

Battelle Memorial Institute

Office of Nuclear Waste

I solation

505 King Avenue

Columbus, $\mathrm{OH} 43201$

Bever ly Rawles

Battelle Memorial Institute

Office of Nuclear Waste I solation

505 King Avenue

Columbus, $\mathrm{OH} 43201$

Research Library

Battelle Memorial Institute

505 King Avenue

Columbus, $\mathrm{OH} 43201$
No. of

Copies

R. Maher, Program Manager Waste Management Programs

Savannah River Plant

E. I. Du Pont de Nemours \& Co.

Aiken, SC 29801

M. D. Boersma

E. I. Du Pont de Nemours \& Co.

Savannah River Laboratory

Aiken, SC 29801

R. G. Garvin

E. I. Du Pont de Nemours \& Co.

Savannah River Laboratory

Aiken, SC 29801

D. L. McIntosh

E. I. Du Pont de Nemours \& Co. Savannah River Laboratory

Aiken, SC 29801

A. L. Ayers

$E G$ \& $G$ Idaho

P.0. Box 1625

Idaho Falls, ID 83415

R. Williams

Electric Power Research

Inst itute

3412 Hillview Avenue

Palo Alto, CA 94304

Environmental Protection Agency

Technological Assessment

Division (AW-559)

Office of Radiation Programs

U.S. Environmental Protection Agency

Washington, DC 20460

J. R. Berreth

Exxon Nuclear Idaho

P.0. Box 2800

Idaho Falls, ID 83401 
No. of

Copies

G. L. Ritter

Exxon Nuclear I daho

P.0. Box 2800

Idaho Falls, ID 83401

J. Campbe 11

Lawrence Livermore Laboratory

P.0. Box 808

Livermore, CA 94550

R. Roy

202 Materials Research Laboratory

Pennsylvania State University University Park, PA 16802

A. L. Lotts

Oak Ridge National Laboratory

P.0. Box $X$

Oak Ridge, TN 37830

A. B. Martin

Rockwe 11 International

Energy Systems Group

8900 DeSoto Avenue

Canoga Park, CA 91304

Paul .Hagen

Chemical Operations

Rockwe 11 Internationa 1

Rocky Flats Plant

P.0. Box 464

Golden, CO 80401

E. Vejvoda, Director

Chemical Operations

Rockwe 11 Internationa 1

Rocy Flats Plant

P.0. Box 464

Golden, CO 80401

R. G. Kepler

Organic and Electronic Dept. 5810

Sandia Laboratories

Albuquerque, NM 87185
No. of

Copies

P. B. Macedo

Keane Hall

Vitreous State Laboratory

The Catholic University of Amer ica

Washington, DC 20017

L. L. Hench

Dept. of Materials Science and Engineering

University of Florida

Gainesville, FL 32611

Dr. Hayne Palmour II I

2140 Burlington Engineering Laboratories

North Carolina State University

Raleigh, NC 27607

ONSITE

4 DOE Richland Operations Office

P. A. Craig (2)

R. E. Gerton

H. E. Ransom

12 Rockwe 11 Hanford Operations

J. S. Buck ingham

T. W. Crawford

J. 0. Honeyman

H. H. Irby

S. M. Joyce

R. M. Orme

I. E. Reep

J. P. Sloughter

C. R. Stroup

D. D. Wodrich (3) 
No. of

Copies

40 Pacific Northwest Laboratory

W. F. Bonner

D. B. Cear lock

T. D. Chikalla

J. W. Finnigan

C. R. Hann

A. J. Haverfield

J. H. Jarrett

R. S. Kemper

D. E. Know 1 ton

L. T. Lakey

D. E. Larson (10)

J. M. Latkovich
No. of

Copies

Pac if ic Northwest Laboratory

(contd)

G. B. Long (3)

R. P. Marshall

J. L. McElroy

R. E. Nightingale

D. E. Olesen

A. M. Platt

J. M. Rusin

R. P. Turcotte

H. H. Van Tuyl

L. D. Willi ams

Technical Information (5)

Publishing Coordination (2) 
!

$=$

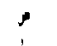

